\title{
Archeological Testing and Monitoring of the Proposed Roma Visitor Complex, City of Roma, Starr County, Texas
}

\author{
Barbara A. Meissner \\ Kristi Miller Ulrich \\ José E. Zapata \\ Center for Archeological Research, University of Texas at San Antonio \\ Steve A. Tomka \\ Raba Kistner
}

Follow this and additional works at: https://scholarworks.sfasu.edu/ita

Part of the American Material Culture Commons, Archaeological Anthropology Commons, Environmental Studies Commons, Other American Studies Commons, Other Arts and Humanities Commons, Other History of Art, Architecture, and Archaeology Commons, and the United States History Commons

Tell us how this article helped you.

This Article is brought to you for free and open access by the Center for Regional Heritage Research at SFA ScholarWorks. It has been accepted for inclusion in Index of Texas Archaeology: Open Access Gray Literature from the Lone Star State by an authorized editor of SFA ScholarWorks. For more information, please contact cdsscholarworks@sfasu.edu. 


\section{Archeological Testing and Monitoring of the Proposed Roma Visitor Complex, City of Roma, Starr County, Texas}

\section{Licensing Statement}

This is a work produced for the Texas Department of Transportation (TxDOT) by the report producer. TxDOT and the report producer jointly own all rights, title, and interest in and to all intellectual property developed under TXDOT's contract with the report producer. The report may be cited and brief passages from this publication may be reproduced without permission provided that credit is given to both TXDOT and the report producer. Permission to reprint an entire chapter, section, figures or tables must be obtained in advance from either the Supervisor of the Archeological Studies Branch, Environmental Affairs Division, Texas Department of Transportation, 125 East 11th Street, Austin, Texas, 78701 or from the report producer. 


\section{Archeological Testing and Monitoring of the Proposed Roma Visitor Complex, City of Roma, Starr County, Texas}

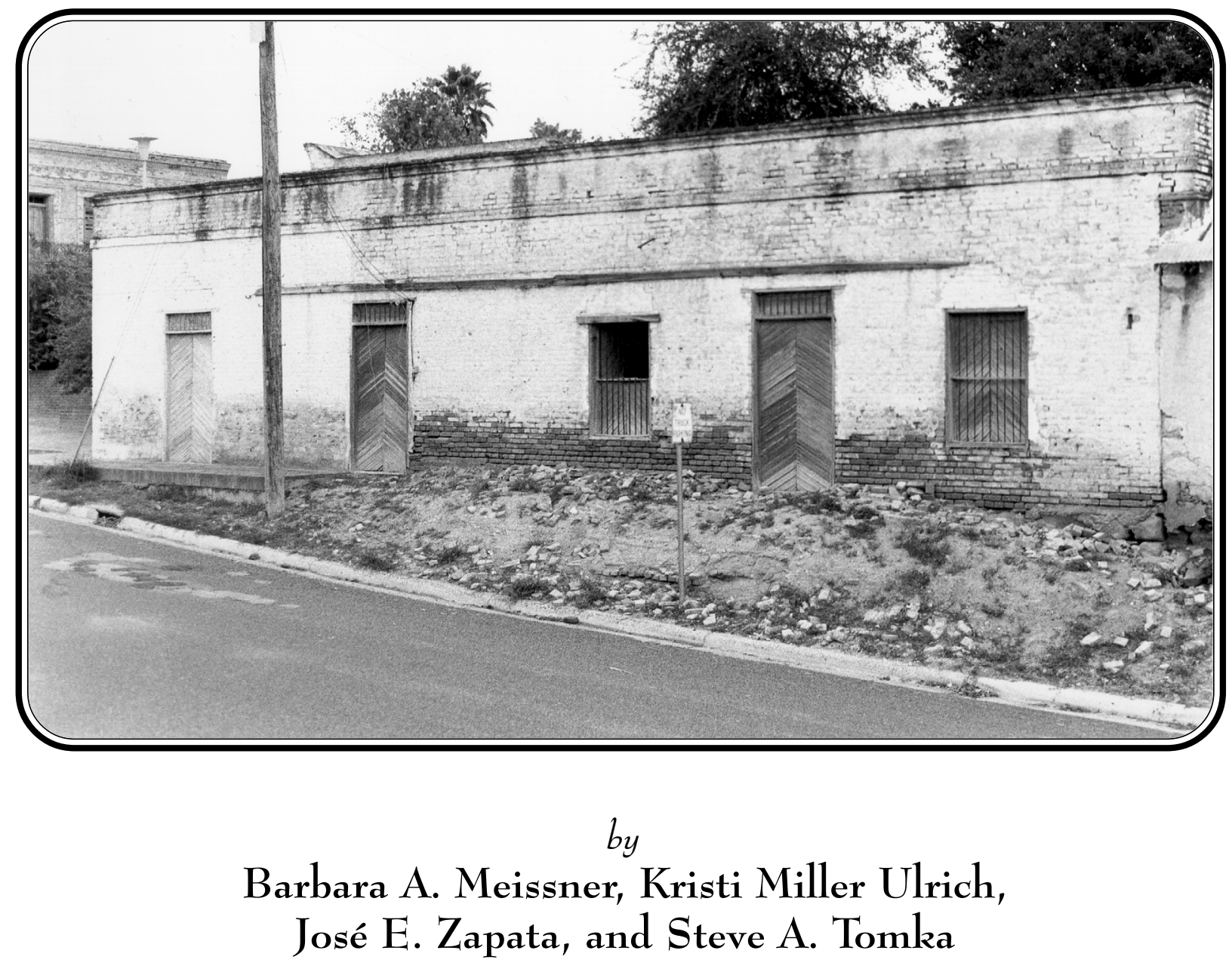

Prepared for:

Kell Muñoz Architects 800 NW Loop 410, Suite 700 N

San Antonio, Texas 78216 with a Contribution by

Jason D. Weston 


\title{
Archeological Testing and Monitoring of the Proposed Roma Visitor Complex, City of Roma, Starr County, Texas
}

\author{
Statewide Transportation Enhancement Program
}

by

Barbara A. Meissner, Kristi Miller Ulrich, José E. Zapata, and Steve A. Tomka

with a Contribution by

Jason D. Weston

Texas Antiquities Committee Permit No. 3052

Steve A. Tomka

Principal Investigator

Prepared for:

Kell Muñoz Architects

800 NW Loop 410, Suite 700 N

San Antonio, Texas 78216

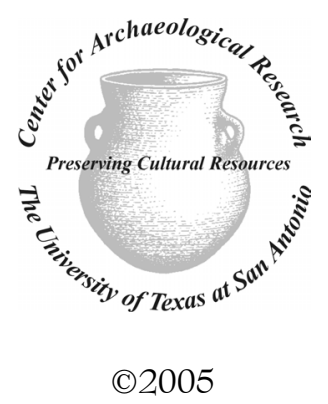

(c)2005
Prepared by:

Center for Archaeological Research The University of Texas at San Antonio Archaeological Survey Report, No. 336 
A list of publications offered by the Center for Archaeological Research is available. Call (210) 458-4378; write to the Center for Archaeological Research, The University of Texas at San Antonio, 6900 N. Loop 1604 W., San Antonio, Texas 78249-0658; e-mail to car@lonestar.utsa.edu; or visit CAR's web site at http://car.utsa.edu. 


\section{Abstract:}

In February and March 2003, staff from the Center for Archaeological Research (CAR) of The University of Texas at San Antonio conducted archeological testing and monitoring within the boundaries of the National Historic Landmark District of Roma, Texas. This work was conducted in partial fulfillment of the requirement of the Programmatic Agreement of the Statewide Transportation Enhancement Program, Section 106 of the National Historic Preservation Act, and the Texas Antiquities Code. The archeological services were conducted under contract with Kell Muñoz Architects of San Antonio and in coordination with the City of Roma and the Pharr District of the Texas Department of Transportation. The sites examined included 41SR210 (Antonia Sáenz Residence), 41SR211 (Stone Cottage), 41SR212 (Rafael García-Ramirez House and Store), 41SR215 (Ramirez Hospital), and 41SR337 (The Coffee Pot Café). This report presents the results of archeological testing and monitoring of areas to be impacted by improvements. The improvements include stabilization of historic building walls, installation of utility lines, and the construction of an amphitheater located in the courtyard. This work supported the information concerning the dates of occupation and construction at each site. The cultural materials found were a mixture of artifacts that likely date to before, during, and after the period of construction of each of the buildings. Because these artifacts were not preserved in an archeological context that dates to a particular historical period of Roma and none were recovered from distinct archeological features from such a time period, none of the archeological deposits investigated can be considered to be National Register of Historic Places (NRHP) eligible. Overall, it is the conclusion of CAR that the substantial construction-related impacts related to the Roma Visitor Complex project will not impact intact cultural deposits. Even areas within the National Historic Landmark District that will be subject to relatively shallow, subsurface disturbances retain no intact cultural deposits that would be eligible for nomination to the NRHP or may be contributing to the existing National Historic Landmark properties. Finally, the one area where cultural materials with limited research value may be encountered will not be adversely impacted by construction activities.

These archeological investigations were conducted under Texas Antiquities Permit No. 3052, with Dr. Steve A. Tomka, CAR Director, serving as Principal Investigator. All cultural materials to be curated were prepared in accordance with federal regulation 36 CFR part 79. All collected artifacts and project-related documents will be permanently curated at the Center for Archaeological Research. 


\section{Table of Contents:}

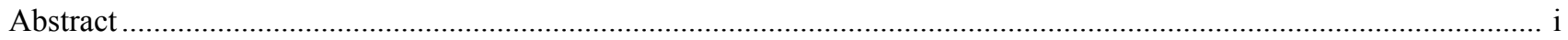

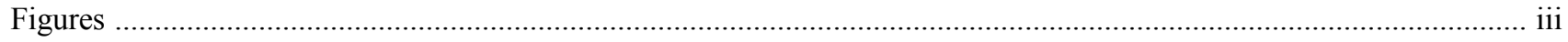

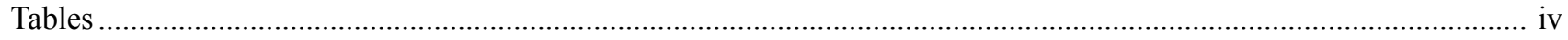

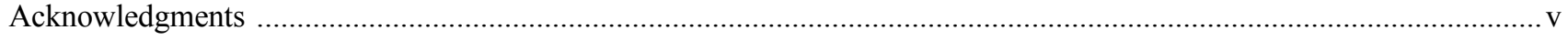

Chapter l: Introduction

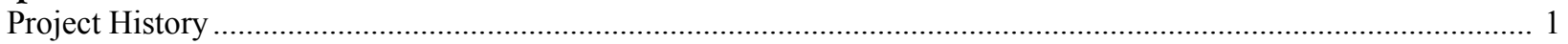

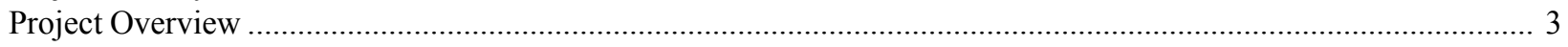

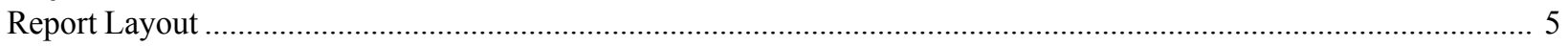

Chapter 2: Historic Background

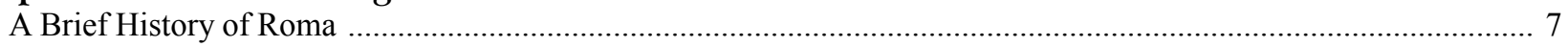

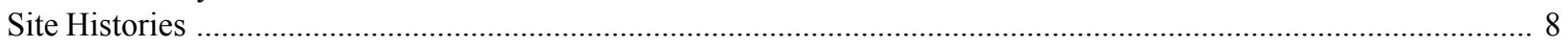

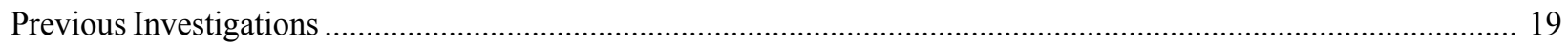

Chapter 3: Levels and Methods of Investigation

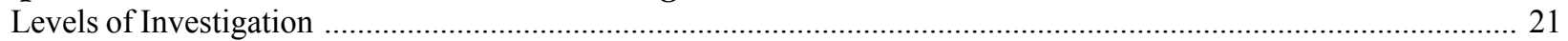

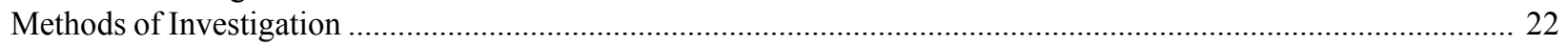

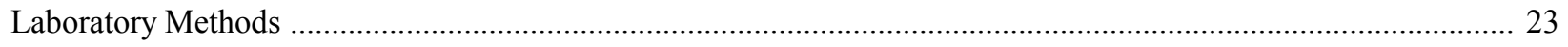

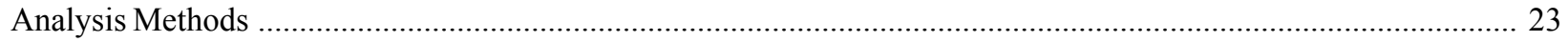

Chapter 4: Results of Investigations

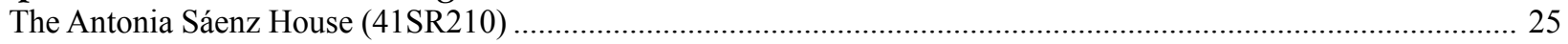

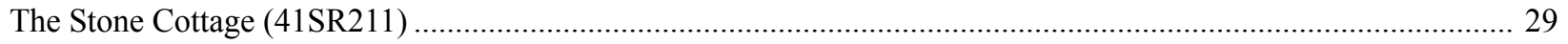

The Rafael García-Ramirez House and Store (41SR212) ............................................................................... 39

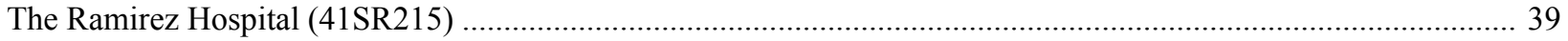

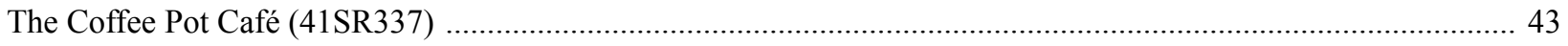

Chapter 5: Summary and Recommendations

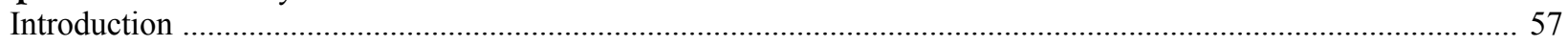

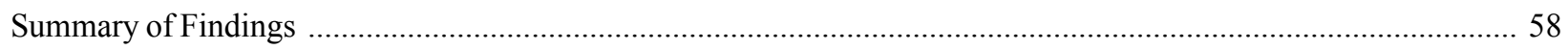

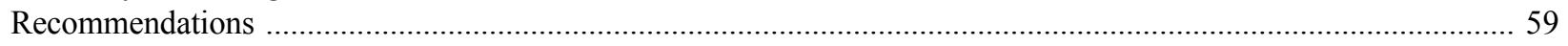

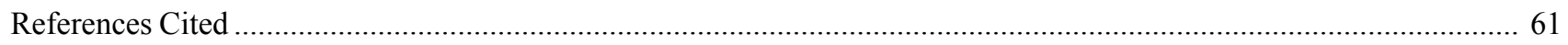

Appendix A: Data from Shovel Tests at 41SR2 11 (Stone Cottage)

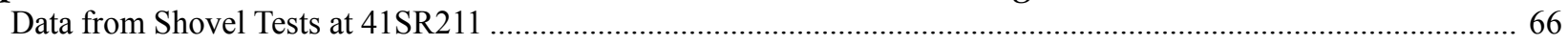

Appendix B: Data from Shovel Tests at 41SR337 (The Coffee Pot Café)

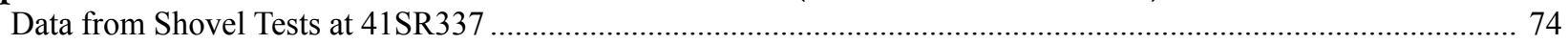




\section{Figures:}

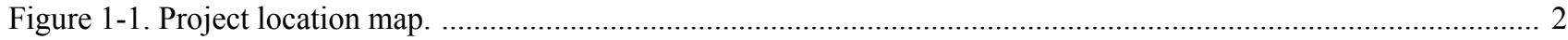

Figure 1-2. Map of sites in Block 8 to be impacted by the Roma Visitor Complex project. .......................................... 3

Figure 1-3. Locations of selected types of construction activities in Block 8 of the Roma National Historic Landmark

District. (a) Archeological and geotechnical testing and utility trenching locations; (b) Demolition floor plan. ........... *

Figure 1-4. Locations of all geotechnical and archeological excavations within Block 8 ............................................. 6

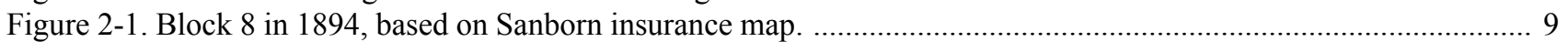

Figure 2-2. The Antonia Sáenz House (41SR210), February 2003 ................................................................... 10

Figure 2-3. Sequence of construction on Lots 1-3, 7, and 8 in Block 8 of the Roma Historic Landmark District. ...... 11-14

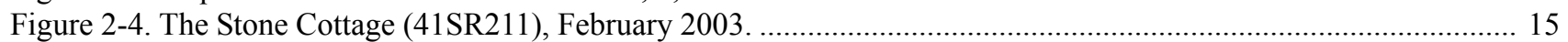

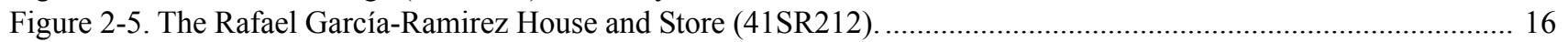

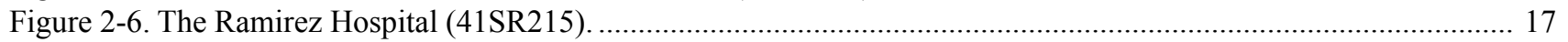

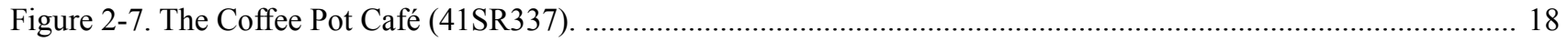

Figure 2-8. Map of project area showing location of previous investigations by Zapata. ............................................ 20

Figure 4-1. Plan of the Antonia Sáenz House (41SR210), showing Test Unit 1, Zapata's unit, and pits dug by PSI........ 25

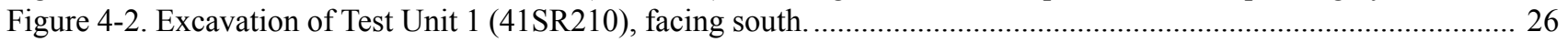

Figure 4-3. Test Unit 1 at the bottom of Level 4a, facing southwest. Note bone and ceramics in pit. ............................ 29

Figure 4-4. Selection of artifacts from Test Unit 1 at 41SR210. ................................................................................ 30

Figure 4-5. Location of shovel tests, Test Units 2 and 3, and PSI Test Pit 1 at 41SR211. ......................................... 31

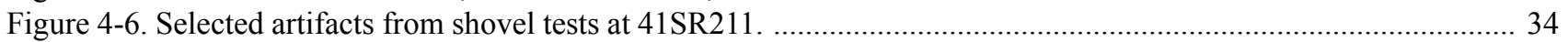

Figure 4-7. Selected artifacts from test units inside the Stone Cottage (41SR211). .................................................. 35

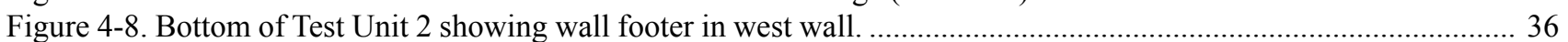

Figure 4-9. Brick floor prior to the excavation of Test Unit 3 in the Stone Cottage, 41SR311 .................................... 38

Figure 4-10. Plan map of the Ramirez House and Store (41SR212), showing locations of PSI test pits. ........................ 39

Figure 4-11. Plan map of the Ramirez Hospital (41SR215), showing locations of Test Units 5 and 6 and PSI test pits. .. 40

Figure 4-12. PSI Test Pit 7, outside the Ramirez Hospital, showing sandstone foundation. ......................................... 43

Figure 4-13. Plan map of The Coffee Pot Café (41SR337), showing test units, shovel tests, and PSI test pits. ............... 44

Figure 4-14. Selected Artifacts from shovel tests in 41SR337. ................................................................................ 47

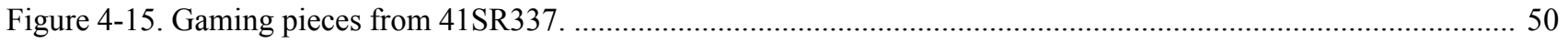

Figure 4-16. Selected artifacts from the test units in 41SR337. ......................................................................... 52

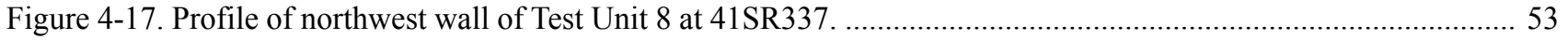

*Oversized maps on CD at back of report. 


\section{Tables}

Table 4-1. Artifacts recovered from Test Unit 1, 41SR210 ...................................................................................... 27

Table 4-2. Artifacts Recovered from Shovel Tests, by Level and Age Class, at 41SR211 …...................................... 32

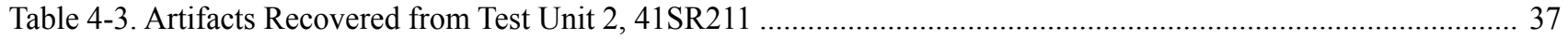

Table 4-4. Artifacts Recovered from Test Unit 3, 41SR211 .................................................................................. 38

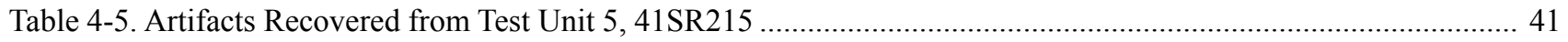

Table 4-6. Artifacts Recovered from Test Unit 6, 41SR215 ................................................................................ 42

Table 4-7. Artifacts Recovered from Shovel Tests, by Level and Age Class, at 41SR337 .......................................... 45

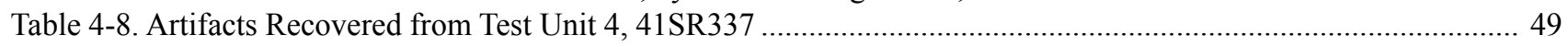

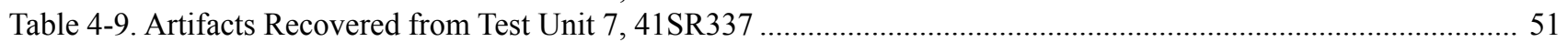

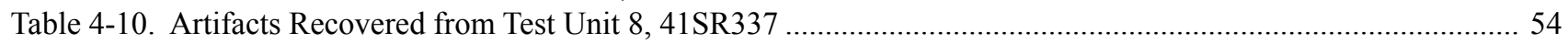

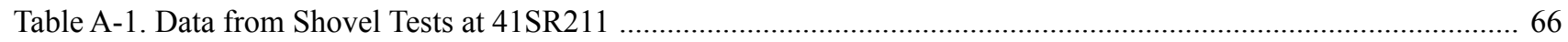

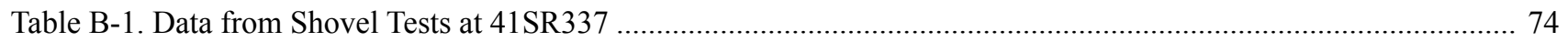




\section{Acknowledgments}

The excavations within the Roma National Historic Landmark District were carried out by the staff of the Center for Archaeological Research (CAR) under contract with Kell Muñoz Architects and were sponsored by ISTEA funds provided by the Texas Department of Transportation. The fieldwork and subsequent analyses and write-up were facilitated by the hard work, dedication, and contributions of many individuals and organizations.

The authors would like to extend their sincere thanks to the personnel of the Environmental Affairs Division of the Texas Department of Transportation. Dr. Owen Lindauer, Mr. Al McGraw, and Mr. Timothy Meade (formerly of TxDOT) worked closely with CAR personnel providing useful and constructive comments during the development of the scope of work and several drafts of the report. We are grateful for the suggestions and assistance they have provided.

Several officials from the City of Roma, as well as crews from the City who removed concrete flouring from areas that were to be excavated, provided much-appreciated assistance during the project. Mr. Steven Tillotson of Kell Muñoz Architects has been instrumental in moving the project forward and providing selected supporting graphics presented in the report. Ismael Adame of Kell Muñoz also provided electronic versions of graphics, his help and assistance are also appreciated. Finally, Jamie Cantu of Petroleum Solutions, Inc. was instrumental in coordinating the excavation of the geotechnical units and the archeological monitoring.

Last, but not least, we extend our thanks and appreciation to all of the crew members who were instrumental in the successful completion of this project. The field crew consisted of Kristi Miller Ulrich, Bryant Saner, and Matthew Senn. They were directed by Barbara Meissner, the project archaeologist. The laboratory staff consisted of Antonia Figueroa, Rebecca Galdeano, Matthew Senn, and Bryant Saner. Jason Weston analyzed the lithic artifacts. Anne Fox and Marybeth Tomka oversaw this group. Bruce Moses and Rick Young of the CAR Graphics Department drafted the illustrations in the report and Johanna Hunziker edited various drafts and formatted the final report. The hard work and dedication of all of these individuals is greatly appreciated. 



\section{Chapter 1: Introduction}

During February and March of 2003, the Center for Archaeological Research (CAR) of The University of Texas at San Antonio conducted archeological investigations at the proposed Roma Visitor Complex (RVC) in partial fulfillment of the requirement of the Programmatic Agreement of the Statewide Transportation Enhancement Program, Section 106 of the National Historic Preservation Act, and the Texas Antiquities Code. This Programmatic Agreement includes coordination among the Federal Highway Administration, the Texas Department of Transportation (TxDOT), the Texas Historical Commission (THC), and the Advisory Council on Historic Preservation. CAR conducted this work under contract to Kell Muñoz Architects, a consulting architectural firm in San Antonio. Kell Muñoz Architects coordinated the scheduling and completion of archeological services with the City of Roma and the TxDOT Pharr District. The results of these investigations are for use by the Federal Highway Administration, TxDOT, and the City of Roma for relevant planning purposes. The archeological investigations were conducted under Texas Antiquities Permit No. 3052, with Dr. Steve A. Tomka, CAR Director, serving as Principal Investigator.

Development of the RVC will impact a portion of the Roma Historic District, a designated National Historic Landmark. Accordingly, the Federal Highway Administration, with TxDOT acting on their behalf, and the City of Roma are bound to the special requirements for protecting National Historic Landmark properties (36 CFR 800.10). In particular, the statutory requirement of 36 CFR 800.10 (a) states, "Section 110(f) of the act requires that the agency official, to the maximum extent possible, undertake such planning and actions as may be necessary to minimize harm to any National Historic Landmark that may be directly and adversely affected by an undertaking."

The purpose of the current archeological investigations was to determine, via manual excavation and through the monitoring of mechanical excavation, (1) whether archeological deposits exist within the Area of Potential Effects of the current project, and (2) whether such deposits may be considered eligible for the National Register of Historic Places. The results of the investigations are summarized in the conclusions that also include recommendations as to whether the proposed Roma Visitor Complex would impact any Register-eligible archeological properties.
The Roma Historic District is currently listed on the National Register of Historic Places (NRHP No. 72001371); therefore, any additional archeological deposits identified through hand excavations and/or monitoring may have the potential of becoming contributing elements to the Historic District.

\section{Project History}

In the fall of 2001, Kell Muñoz Architects of San Antonio approached CAR concerning the status of the Roma Restoration Project (RRP) that had taken place during 1993 1997 in the City of Roma (Figure 1-1). The RRP was initiated in 1993 after The Conservation Fund, representing The Meadows Foundation (owner), joined the Texas Parks and Wildlife Department (contractor) to stabilize the buildings of eight of the central properties in the Roma National Historic Landmark District, in accordance with the Secretary of Interior's Standards for Historic Preservation Projects (36 CFR 67). Archeologist José E. Zapata, formerly of the Center for Archaeological Research, served as project archeologist throughout Phase I and part of Phase II of the project during 1993-1997.

Phase I of the RRP consisted of property acquisition and preliminary site work including the cleaning of the sites and structural stabilization and waterproofing. It took place between 1993 and 1994 and was funded by The Meadows Foundation of Dallas. Phase II focused on the preservation and restoration of exterior components (e.g., roofs, decking, masonry walls, doors, windows, and hardware) of four historic properties within the district (see section on previous investigations in Chapter 2). While Phase II took place between 1995 and 2000, the selection of the proposed RRP for transportation enhancement funds occurred in 1994 as a result of the First Call of the transportation enhancement program. Monies for Phase II included funding from the Texas Statewide Transportation Enhancement Program as a result of the requirements of the Intermodal Surface Transportation Efficiency Act (ISTEA). ISTEA was a U.S. Department of Transportation program and stipulations for the inclusion of enhancement funding was a portion of that program. However, the Texas Statewide Transportation Enhancement Program determined how the funding was applied and distributed in Texas and how the City of Roma received the funding. 


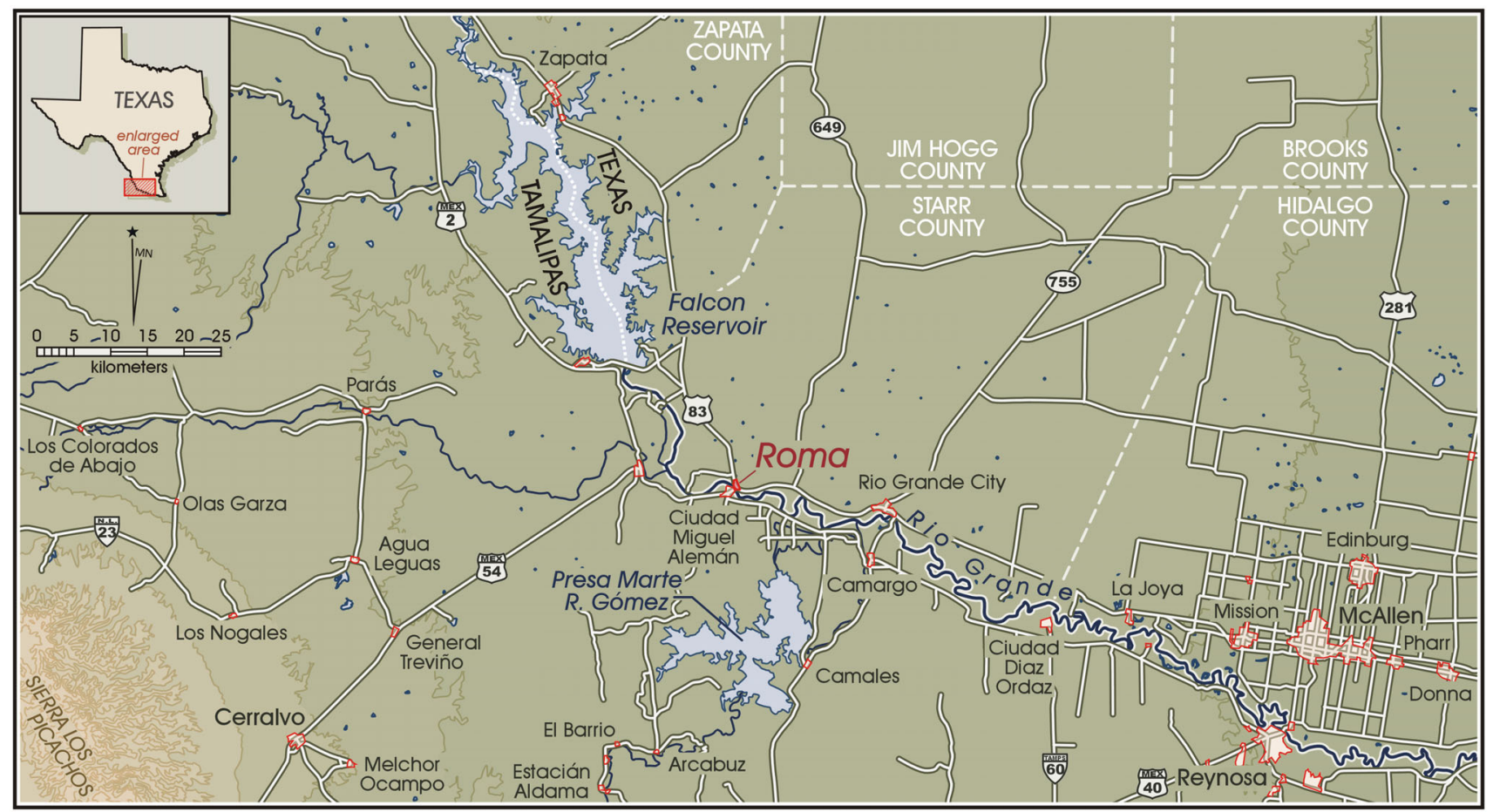

Figure 1-1. Project location map.

The town of Roma was established in August 1848 (Zapata 2002:6). It is located in southwest Starr County and is situated between Laredo (90 miles to the northwest) and McAllen (80 miles to the southeast), along U.S. Highway 83. The town was laid out on a sandstone bluff, overlooking the Rio Grande, and its plat was configured in a grid pattern. The Roma Historic District, a 15-block area encompassing approximately 43 historic commercial, residential, and religious structures, was listed on the NRHP in 1972 and designated a National Historic Landmark in 1993.

Information obtained during the archival, architectural, and archeological investigations associated with the RRP serves as a critical foundation for any future developments, such as the Roma Visitor Complex (RVC) proposed within the Roma Historic District. The proposed RVC, funded in part by ISTEA, is to occupy most of Roma City Block 8 , adjacent the plaza. The goal of the project is to reintegrate the buildings into the community once the restorations are complete. The RVC will result in various levels of disturbance in Lots $1,2,3,7$, and 8 within the block (Figure 1-2). Specifically, the following properties/sites are to be impacted:
1. The Antonia Sáenz House — 41SR210 (Lot 3), constructed circa 1884;

2. The Stone Cottage - 41SR211 (Lot 2), constructed circa 1850;

3. The Rafael García-Ramirez House and Store 41SR212 (Lot 1), constructed circa 1870;

4. The Ramirez Hospital - 41SR215 (Lot 8), constructed circa 1856; and

5. The Coffee Pot Café — 41SR337 (Lot 7), original buildings constructed before 1894 .

Following restoration of selected structures within these five historic properties, the RVC will utilize the buildings as exhibit space, conference rooms, reception and office space, and maintenance and public facilities. The courtyard bounded by the five properties will be used for outdoor exhibits. 


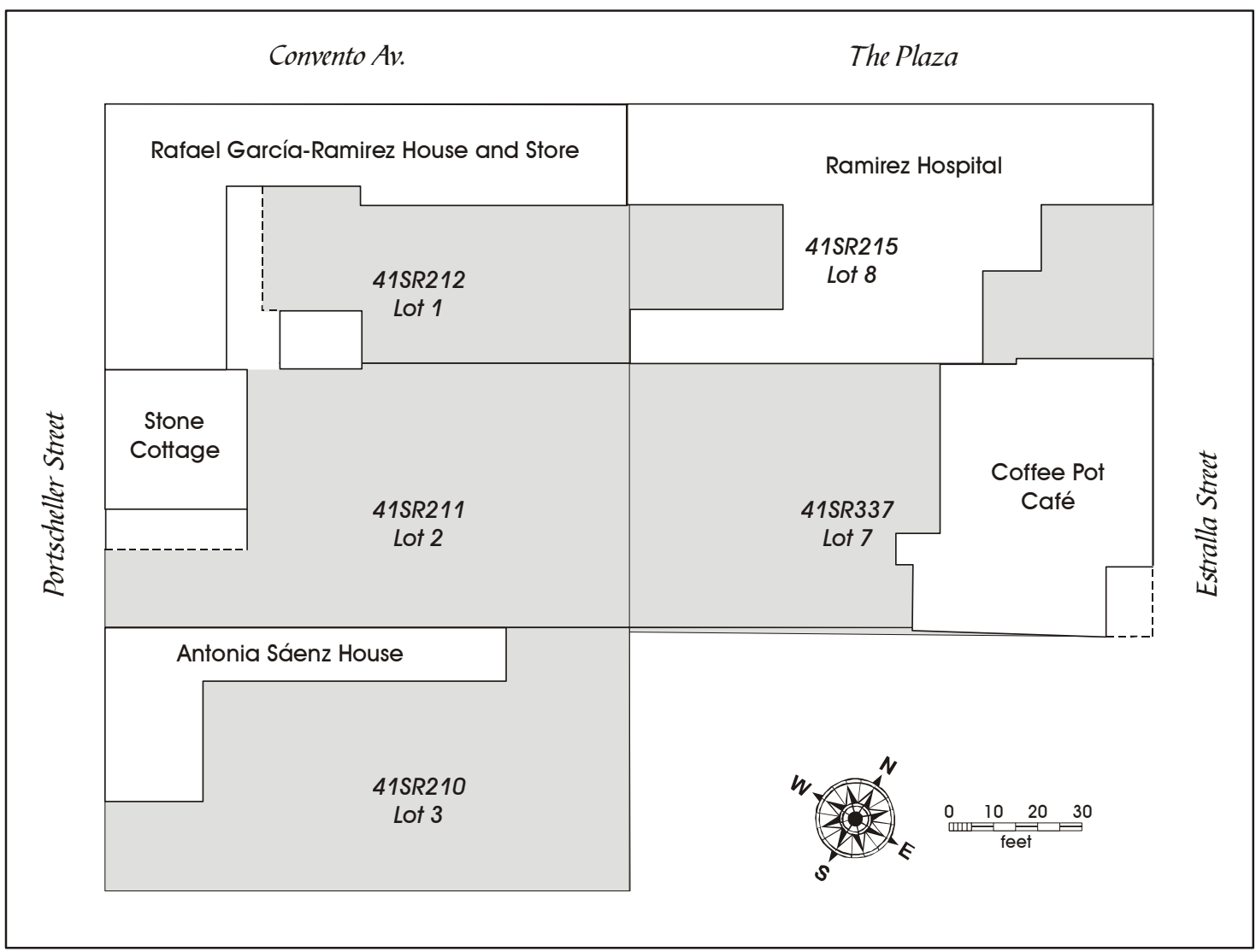

Figure 1-2. Map of sites in Block 8 to be impacted by the Roma Visitor Complex project.

With the exception of The Coffee Pot Café (41SR337) and the Ramirez Hospital (41SR215), the other three historic properties had been the subject of either archival research, architectural restoration, or archeological investigations or some combination thereof during the RRP.

Although a technical report detailing the findings of the RRP has not yet been published, the initial interest on the part of Kell Muñoz Architects spurred renewed interest to complete the analysis of the materials and publication of a technical report detailing the findings of the RRP. In addition, because the construction of the RVC would have to begin prior to the completion of the report, and the subsurface disturbances to historic properties within the block were to be relatively extensive, Kell Muñoz Architects contracted with CAR (January 2003) to provide archeological services associated with the planned construction.

\section{Project Overview}

\section{The Overall Area of Potential Effects}

The Area of Potential Effects associated with the planned construction of the RVC includes, but is not limited to, all historic properties within Block 8 of the Roma Historic District, though the types and degree of subsurface impact varies within and between the five sites (see Figure 1-3, a and $b$, on $C D$ in pocket at the back of this report). Overall impacts will include a range of actions including the demolition of non-historic intrusive additions to the historic structures, restoration of historic structures, renovations of one non-historic structure, landscaping and site work, utility, mechanical and electrical improvements, signage installation, and pedestrian improvements and linkages to the adjacent plaza and banquetas (sidewalks). 
Specifically, a review of Figure 1-3a indicates that within the Rafael García-Ramirez House and Store (41SR212), one structure, connecting the 1880 s portion of the complex with a 1960s addition, will be demolished. The other structures slated for removal include a series of 1920-1940 additions along the southern and eastern portion of the Ramirez Hospital (41SR215), a 1940-1960s structure west of The Coffee Pot Café (41SR337), and a porch addition at the southern end of the Stone Cottage (41SR211).

Given new construction techniques and codes, the Roma Visitor Complex project will result in sub-floor disturbances to the majority of the structures within the block. Present construction plans indicate that, with the exception of the floor in The Coffee Pot Café, the floor in the remaining 1960s additions to the Rafael García-Ramirez House and Store, and the floor of a small 1920-1940s structure immediately behind the Ramirez Hospital building, all other structures within the five sites in this block will be impacted. Floor impacts will consist of the excavation of all existing matrix and/or fill to a depth of approximately 14 inches within the structures. The new interior surfaces will be built on a six-inch base, covered by a four-inch concrete layer and topped with a four-inch brick surface.

In addition, new foundation trenches will be excavated along the interior and exterior of all buildings. Trenches will vary from 12-24 inches deep and 18-24 inches wide. Subsurface stone rubble wall footings will be removed and replaced with reinforced concrete. Additional six-inch wide and sixinch deep trenches will impact the courtyard east of the Rafael García-Ramirez House and Store (41SR212) and east of the Antonia Sáenz House (41SR210; Figure 1-3b). This network of trenches will house water pipes for the irrigation system that will service these areas. Finally, multiple adjacent trenches will be excavated along the back walls of the Stone Cottage and the Rafael García-Ramirez House and Store, behind The Coffee Pot Café and Ramirez Hospital properties, and across the courtyard east of the Stone Cottage. The individual trenches will vary from 18 36 inches wide and range in depth from 12-36 inches. The trenches will house sanitary sewer lines, water lines, CATV, telephone, and power lines.

Three areas will require the removal of existing slab or terrazzo tile surfaces. One of these is located immediately east of the Stone Cottage (41SR211) where the slab is approximately six inches thick. The other two areas are located in The Coffee Pot Café property (41SR337). One of these is a small room with a terrazzo tile floor located immediately west of The Coffee Pot Café and the other is a small patio immediately south of the Café.

Changes to existing grade will occur in a number of places across the block. In the courtyard east of the Stone Cottage (41SR211) the construction of an amphitheater will require the removal of approximately six inches of fill from the southwestern portion of the courtyard and the addition of between six and 12 inches of fill across the northern half of the amphitheater location. The existing grade will be downcut by 6-12 inches along the eastern edge of the Rafael García-Ramirez House and Store (41SR212) property, as well as immediately south of the Antonia Sáenz House (41SR210) to provide appropriate grade for the construction of an ADA-accessible ramp. Approximately six inches of matrix will be removed from across the courtyard of the Antonia Sáenz House (41SR210). Fill will be introduced across two portions of the block. The southeastern half of the courtyard west of The Coffee Pot Café will receive approximately one foot of fill with the fill increasing in thickness adjacent the southwest corner of the courtyard. About one to two feet of fill will also be introduced in an area immediately west of The Coffee Pot Café.

Finally, while the previously described impact will occur within the inside of the block and lots, the reconstruction of the banquetas will result in subsurface impacts along Portscheller Street in front of the Antonia Sáenz House and the Rafael García-Ramirez House and Store. A small section of the banquetas in front of The Coffee Pot Café along Estrella Street will also be restored. The subsurface disturbances associated with these impacts will reach to an approximate depth of two feet below present grade.

\section{Impacts Associated with the Current Project}

The most immediate subsurface impacts to these properties consisted of geotechnical drill rig and hand-auger borings, concrete cores for slab thickness checks, and excavations to check foundation beam depths and widths. The location of the geotechnical exploratory work is shown in Figure 1-4. The four three-inch diameter drill rig borings penetrated to a depth of 15 feet, while the five hand-auger borings only reached to a depth of five feet. The four concrete cores penetrated only through concrete slabs and had no or only minimal impact to underlying matrix. One of the concrete cores was in the floor of the original structure of the Stone Cottage. This structure was built between 1850 and 1870, but it is not known how much later the concrete floor was 
added. The second concrete core was in the slab floor of a circa 1960 addition to the García-Ramirez House and Store while the third core was in the slab floor of a 1870-1890 addition to the Ramirez Hospital. The fourth and final concrete core was through the slab floor of The Coffee Pot Café. This structure was built sometime before 1894, but it is not known when the slab floor was poured. Of the nine 3-x-3-foot geotechnical test pits, seven were to be excavated along the outside of walls including one each along the Antonia Sáenz House and the Stone Cottage, two along walls of structures within the Ramirez Hospital and three along walls of structures in The Coffee Pot Café property. In addition to these seven exterior units, two interior units were to be dug within buildings of the Rafael García-Ramirez House and Store. The test units were to be excavated using shovels and picks to a depth of 3-4 feet.

The archeological services were to consist of monitoring of subsurface excavations associated with geotechnical services, manual excavation of test units within and outside of selected structures dating to circa 1850 , and systematic shovel testing within the courtyard enclosed by the structures associated with the five historic properties within the block. Numerous phases of construction have taken place and modified many of the structures within Block 8 . Because the early days of the founding of the City of Roma were the least well known and documented archeologically, in meetings with the THC, TxDOT, Kell Muñoz Architects, and CAR, it was decided that archeological investigations were to concentrate on structures and portions of the five sites that date to circa 1850 . Additional monitoring and excavation efforts would be concentrated on the identification of 1850 s deposits within the courtyard bounded by the structures in Block 8. The scope of work included the following specific archeological tasks:

1. Test interior sub-floor areas within the two circa 1850s structures - the Stone Cottage (41SR211) and Ramirez Hospital (41SR215) - for undisturbed cultural materials dating to circa 1850 ;

2. Test for remains of early outbuildings associated with The Coffee Pot Café site (41SR337);

3. Determine the age of the pre-1870s midden identified by Zapata (2002) adjacent to the east wall of the Antonia Sáenz House;

4. Locate any 1850 s refuse dumps within the existing courtyard enclosed by the structures located in Block 8; and
5. Monitor the geotechnical borings and test units in previously unexcavated areas for cultural materials dating to around 1850.

Overall, the geotechnical tasks (borings, concrete cores, and excavation units adjacent foundations) were necessary to characterize the present state of the standing structures and also probe the matrix beneath the structures and in the courtyard to determine whether archeological deposits were present that might be disturbed by the installation of utilities and other improvements. The archeological monitoring of boring holes and geotechnical units and the hand excavation of 1-x-1-meter test units by CAR were designed to identify and assess whether the proposed RVC enhancement project would impact archeological properties and/or deposits eligible to the National Register of Historic Places and/or contributing components to the National Historic Landmark District. It was hoped that with the information obtained about the nature and integrity of archeological properties associated with the standing structures, it would be possible for the City of Roma and its design consultants to avoid adversely impacting the National Historic Landmark.

The hand-excavation of test units and shovel tests, and the monitoring of a portion of the geotechnical investigations, occurred between February 12 and March 4, 2003. This technical report details the results of the archeological investigations and makes recommendations regarding the impact of proposed subsurface disturbances associated with the construction of the Roma Visitor Complex upon the five historic properties.

\section{Report Layout}

This report is divided into five chapters and two appendices. Following this introductory chapter, the Historic Background (Chapter 2) provides a brief history of the City of Roma and of the individual properties subjected to archeological investigations. Chapter 3 describes the field, laboratory and analytical methods employed during this project. Chapter 4 summarizes the results of the investigations at each of the sites. The final chapter, Chapter 5, summarizes the findings of the investigations for each historic property and makes recommendations related to additional investigations necessary in light of the information obtained during this project. Appendices A and B list artifacts recovered from the shovel tests at sites 41SR211 (Stone Cottage) and 41SR337 (The Coffee Pot Café), respectively. The CD at the back of this report contains Figures 1-3a and 1-3b, oversized construction maps. 


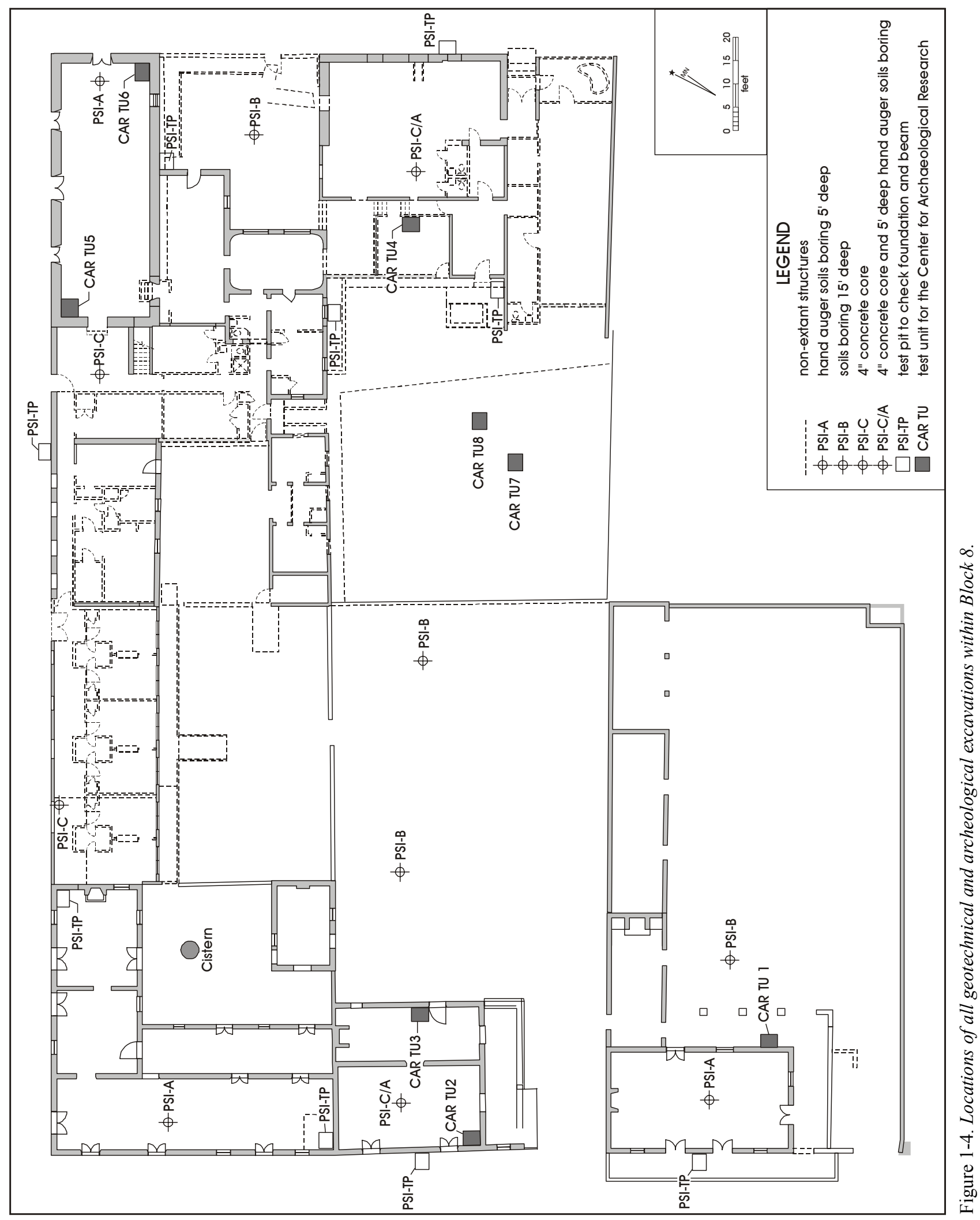




\section{Chapter 2: Historic Background}

This chapter presents a brief history of the City of Roma, based largely on the work carried out by Zapata (2002). Following this are individual site histories, taken from much more detailed descriptions available in Fox et al. (n.d.) and Zapata (2002). Details of the architectural descriptions were provided by Mr. Steve Tillotson of Kell Muñoz Architects.

\section{A Brief History of Roma}

Very little is known about the prehistoric inhabitants of the area around Roma before the arrival of the Spanish (Hester 1995). The Native Americans in South Texas were huntergatherers living in small and highly mobile bands. Recent studies (i.e., Mahoney et al. 2002; Quigg et al. 2000; Quigg et al. 2002) in the region, however, have further defined prehistoric subsistence and adaptation along the Rio Grande.

Several studies have been conducted on the Protohistoric, or contact period, along the Rio Grande and Falcon Reservoir areas. For this region, the contact period commences at that point in time when native inhabitants first encountered Europeans, specifically the Cabeza de Vaca expedition on the 1530s. Early surveys work conducted in the region include those of Swanton (1940) and Hartle and Stephenson (1951). Comprehensive reports detailing the various native groups extant during the contact period include the works of Ruecking (1955) and Salinas (1990). Other studies include those of Goddard (1979), wherein the complexity and probable non-Coahuilteco linguistic affiliations of native groups in the lower Rio Grande are discussed, and those of Campbell and Campbell (1981), wherein the subsistence of Protohistoric native groups of the region are discussed.

The beginning of eighteenth-century European settlement in Nuevo Santander, between the Nueces and the Panuco rivers, was the result of the assignment of Don José de Escandón to settle and civilize the area along the lower Rio Grande. The town of Mier, the northernmost settlement established at that time, was chartered in 1752, surveyed, and the surrounding land divided into porciones. These were long, narrow strips of land perpendicular to the river, which were granted to colonists. Two of these tracts north of the river and upstream from Mier were assigned to Juan Salinas and Juan Angel Sáenz, who founded ranches on their property after 1767 (Zapata 2002:26). A small ranching community known as Rancho de Jesús de Buena Vista was located approximately where the historic center of Roma now lies, although the exact location of this community is not known (Zapata 2002:30). Although no archeological indicators of this earlier occupation of the locality were found in the previous work at Roma, some material and perhaps even architectural manifestations of this occupation may remain buried under the historic and modern debris.

The town of Roma was formally established six months after the Treaty of Guadalupe Hidalgo in 1848. The name was suggested by the Oblates of St. Mary Immaculate who founded a mission there in the 1850s (Heller 2002). The majority of the early town settlers were Anglo Americans, some from as far away as New Orleans and New York City, but by 1865 , local Tejano and Mexican entrepreneurs were buying them out (Zapata 2002).

Roma was the farthest point upstream to which a steamboat could travel. Spurred by the arrival of Anglo American merchants after Texas joined the Union in 1845 , a steamboat landing was located at the base of the sandstone bluff. A ferry connecting Roma to Mexico had been established by the late eighteenth century (Zapata 2002). Charles Stillman went into business with riverboat captains Mifflin Kenedy, Richard King, and James O'Donnel to establish a monopoly of transportation on the river.

During the Civil War, due to the high tariffs enforced by Mexico and the blockade of the mouth of the Rio Grande by the Union, "smuggling" became a highly profitable enterprise (O'Malley et al. 1976:4). Tyler (1973:104) notes:

The cotton had to be hauled by wagon from the principal market centers of Texas to the border towns. It was a difficult journey because much of the trip had to be made over semi-arid or desert country. ...Pryor Lea, the Texas agent in Brownsville, suggested that the primary route to the river be divided into three parts: from Alleyton (the end of the railroad) to Goliad, Goliad to the King ranch, and the King Ranch to some navigable point on the Rio Grande such as Brownsville, Rio Grande City, or Roma. 
It should be noted that "smuggling" referred to the trade of items considered illegal by the Confederate government; however, the Confederacy considered the transport of cotton along alternate land and sea routes to avoid a Union blockade as legitimate commerce.

After the war, the "boomtown" effect subsided, somewhat. By 1893, a customs house and several general stores were active in serving both the residents and the surrounding ranches (Figure 2-1). The first international suspension bridge crossing the Rio Grande, linking Roma with the town of San Miguel Alemán, was constructed in 1927 and a new concrete bridge was built in 1979 (Heller 2002), continuing the intimate connection between Roma and Mexico.

\section{Site Histories}

\section{The Antonia Sáenz House (41SR2 10)}

The Antonia Sáenz House, constructed circa 1884 by Heinrich Portscheller, a German architect, builder, and mason of the Rio Grande valley, is an excellent example of vernacular residential architecture utilizing molded brick construction techniques that have become associated with the architecture of the region (Figure 2-2a). The building sits on Portscheller Street, between Convento Avenue and Juarez Alley. The Rio Grande is approximately 60 m (200 feet) west-southwest of the building. The Antonia Sáenz House is located one block west of the International Bridge.

The original building has an L-shaped plan consisting of a one-story brick masonry structure measuring approximately 23 by 41 feet overlooking Portscheller Street and a 13-by29-foot kitchen extension to the rear overlooking the lower plaza. The principal facade and main room of the house face the street, and the façade is characterized by raised surrounds and cornice caps at doors and windows and a continuous parapet cornice. The roofing is concrete and brick tile and interior walls are plastered and painted and the floor retains the original brick construction. The main room of the house has a fireplace, plaster walls, and a brick floor (Figure 2-2b). The attached kitchen also retains the original brick flooring and a fireplace at the east end. A brick paved patio addition was built against the southeast wall of the main house sometime circa 1894, and may have wrapped around the north side of the building. A one-story brick masonry rectangular structure, measuring approximately 13 by 40 feet, was added to the kitchen and an open-arched stable, 13 by 28 feet, was added to this at the north end. A brick masonry privy is located at the southeastern corner of the property.

Archival records and oral histories indicate that this site/ structure was utilized as a residence and possibly as a schoolhouse. Based on available abstracts, Block 8, Lot 3 (and the adjoining lot to the west) was owned by Robert Margo, who married Antonia Sáenz.

Figures 2-3a through 2-3g present the sequence of construction on Lots $1-3,7$ and 8 , in Block 8 of the Historic Landmark District. The reader should consult these figures when reviewing the site histories in this chapter.

\section{The Stone Cottage (41SR211)}

Located on Lot 2 of Block 8, about $55 \mathrm{~m}$ (180 feet) northeast of the Rio Grande, is a one-story, three-room structure of sandstone rubble (Figure 2-4a). It was primarily a residence, although it may have had some use as a repair shop in its last years of occupation.

The house was built circa 1850 and was in use until about 1950. This structure was part of the first settlement built around the steamboat landing established by King, Stillman, and Kenedy (O'Malley et a1. 1976:4). The original building is a one-story stone masonry rectangular plan house measuring approximately 20 by 33.5 feet with a gable parapet on the north. The north wall abuts and predates the Ramirez House. The original house had a shingle roof while the present building has dressed lumber members supporting a corrugated metal roof. The floor of the structure is concrete and the exterior walls are stuccoed and the interior walls are plastered. The interior ceiling was originally finished in canvas, although only segments remain today. A 12.5-by33.5-foot shed was added to the rear of the original building sometime between 1870 and 1880 . The floor of the addition is brick and its north wall is formed by a brick masonry kitchen fireplace (Figure 2-4b). A porch was added to the southeast end of the original structure and this porch was later extended to encompass the entire south wall. The porch on the south end of the building became a wood frame enclosure circa 1925-1935 (Figure 2-4a), but this room has since been almost completely dismantled, except the wall that faces the street. 


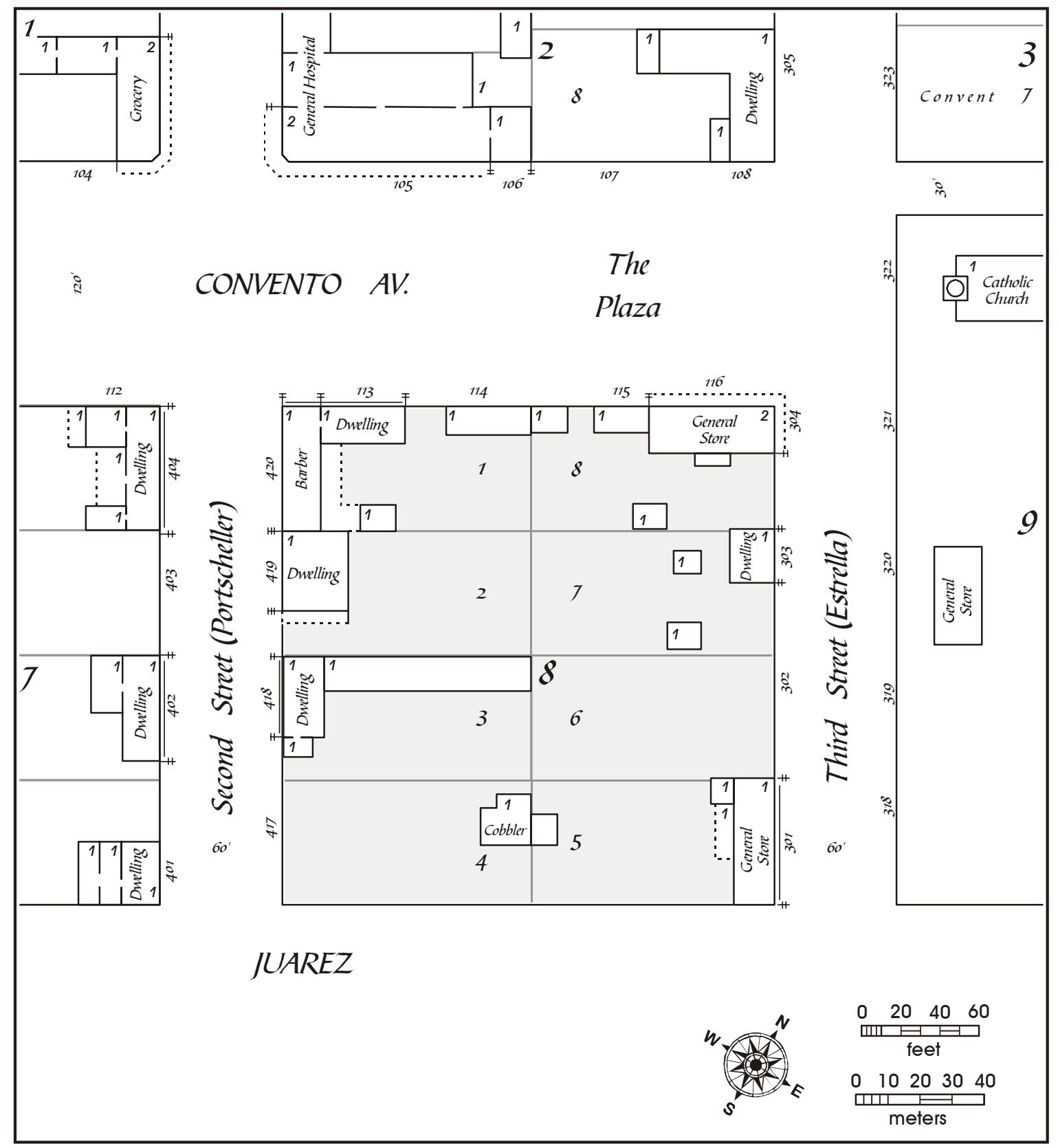

Figure 2-1. Block 8 in 1894, based on Sanborn insurance map. 


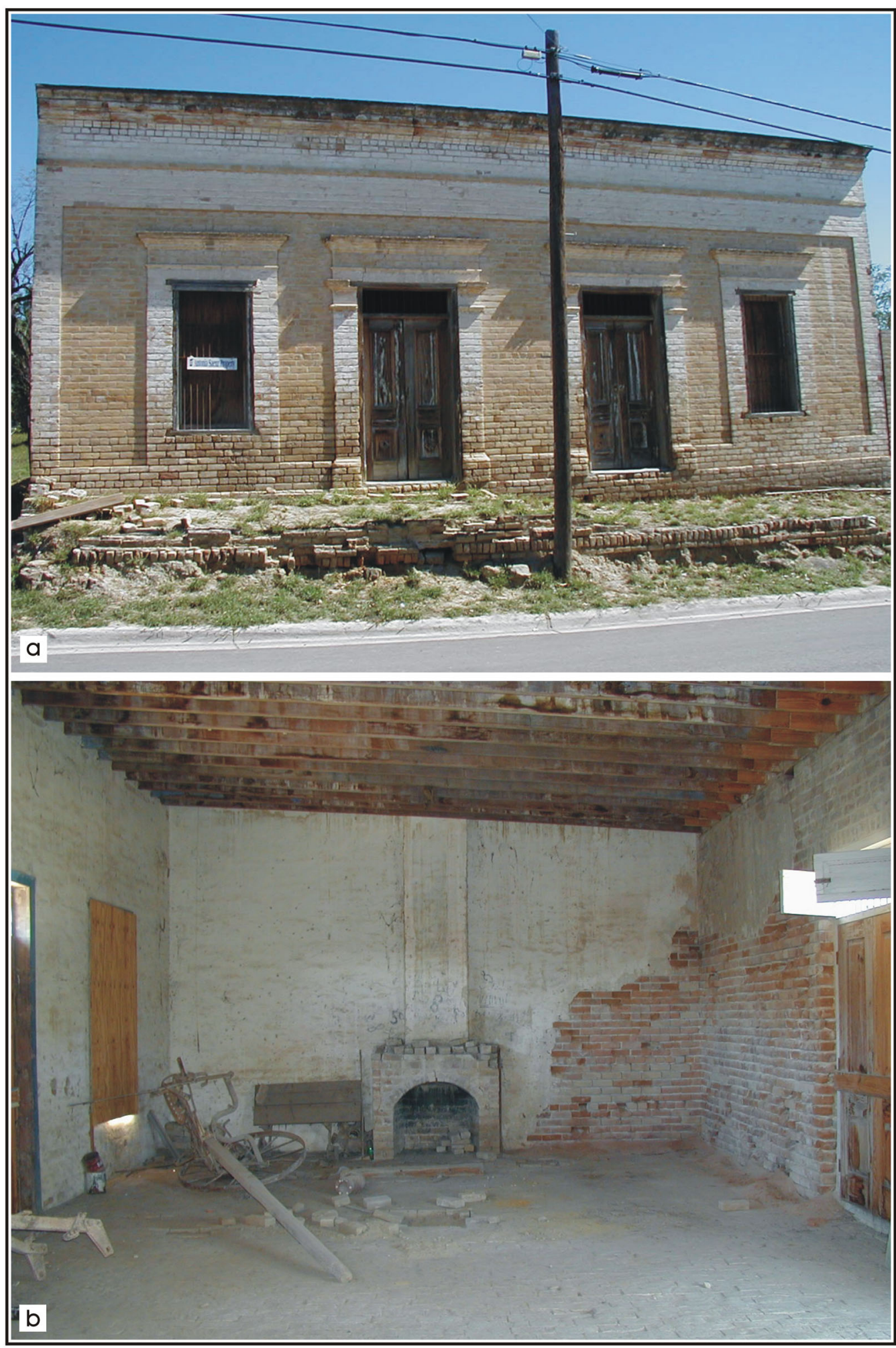

Figure 2-2. The Antonia Sáenz House (41SR210), February 2003. (a) front of house facing Portscheller Street; (b) main room of house. 


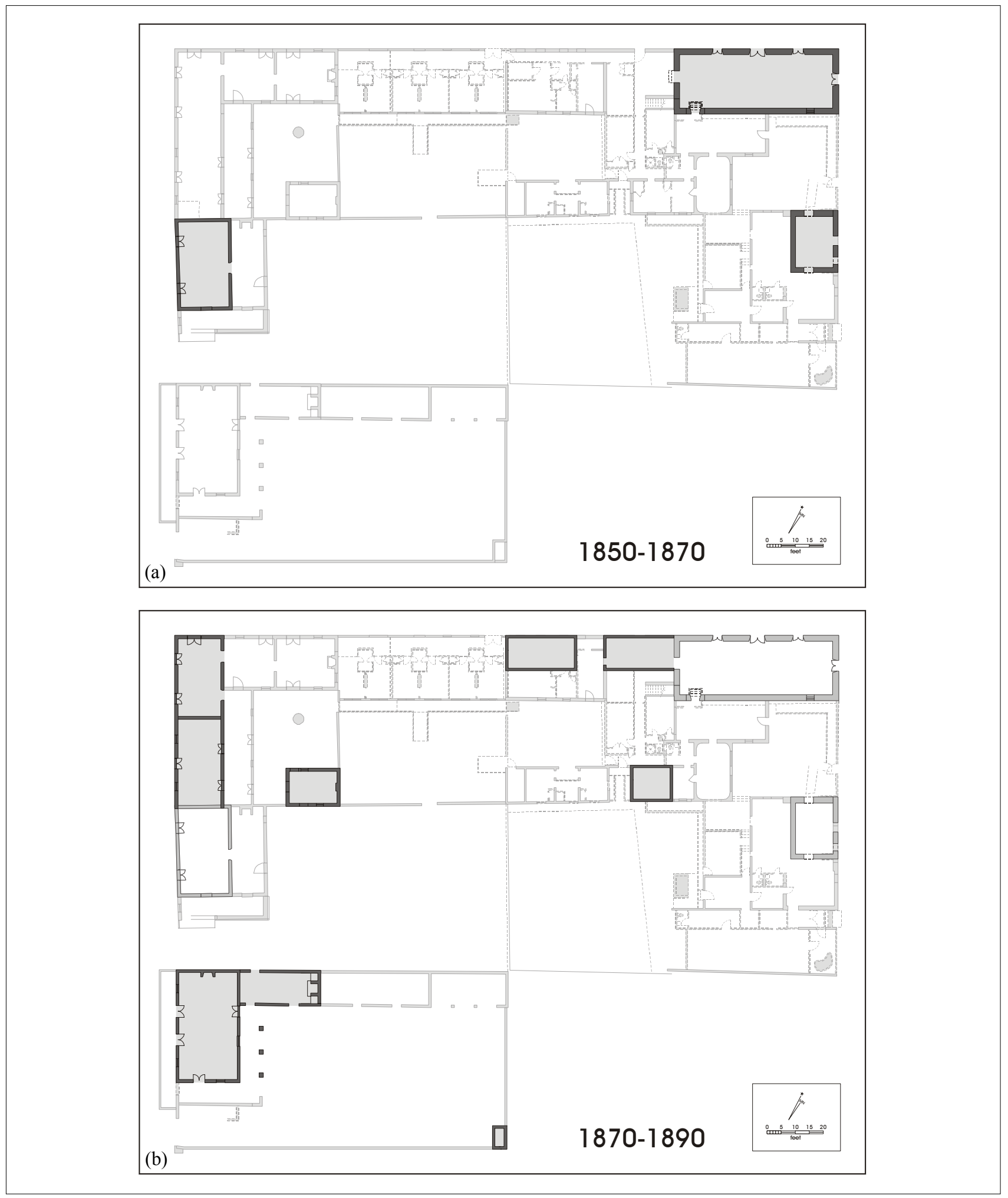

Figure 2-3. Sequence of construction on Lots 1-3, 7, and 8 in Block 8 of the Roma National Historic Landmark District. (a) 1850-1870; (b) 1870-1890. 

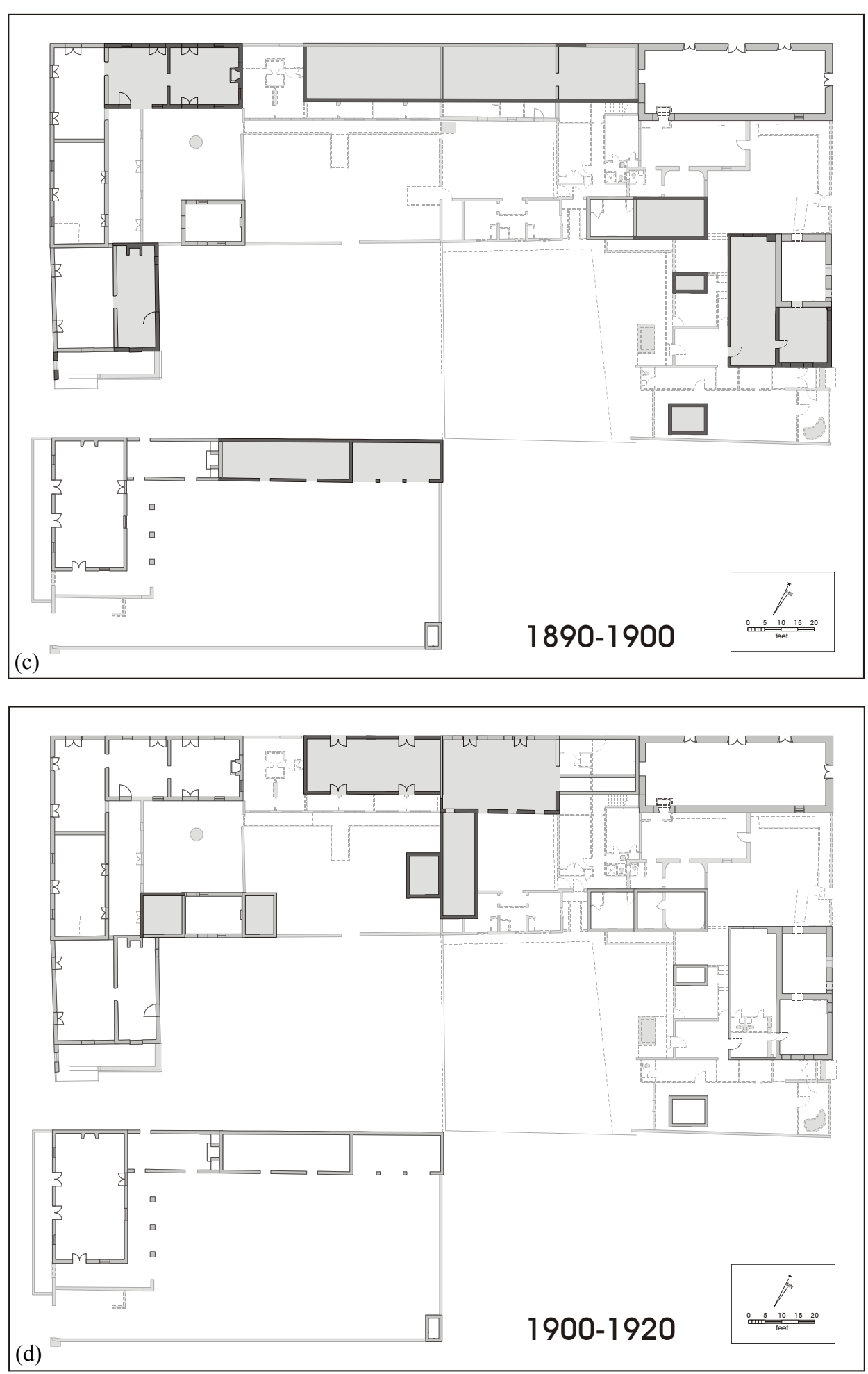

Figure 2-3. Sequence of construction continued ...(c) 1890-1900; (d) 1900-1920. 


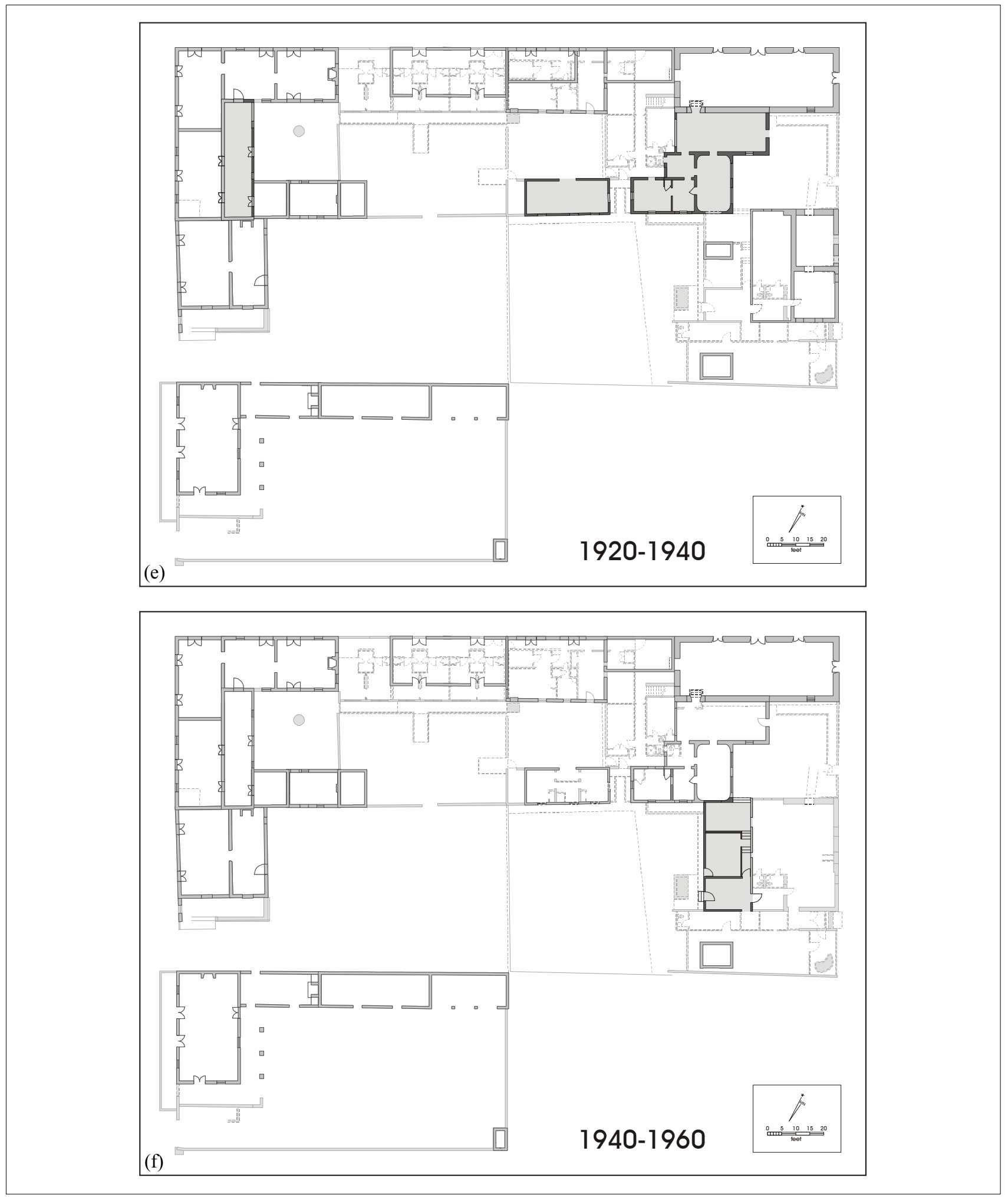

Figure 2-3. Sequence of construction continued...(e) 1920-1940; (f) 1940-1960. 


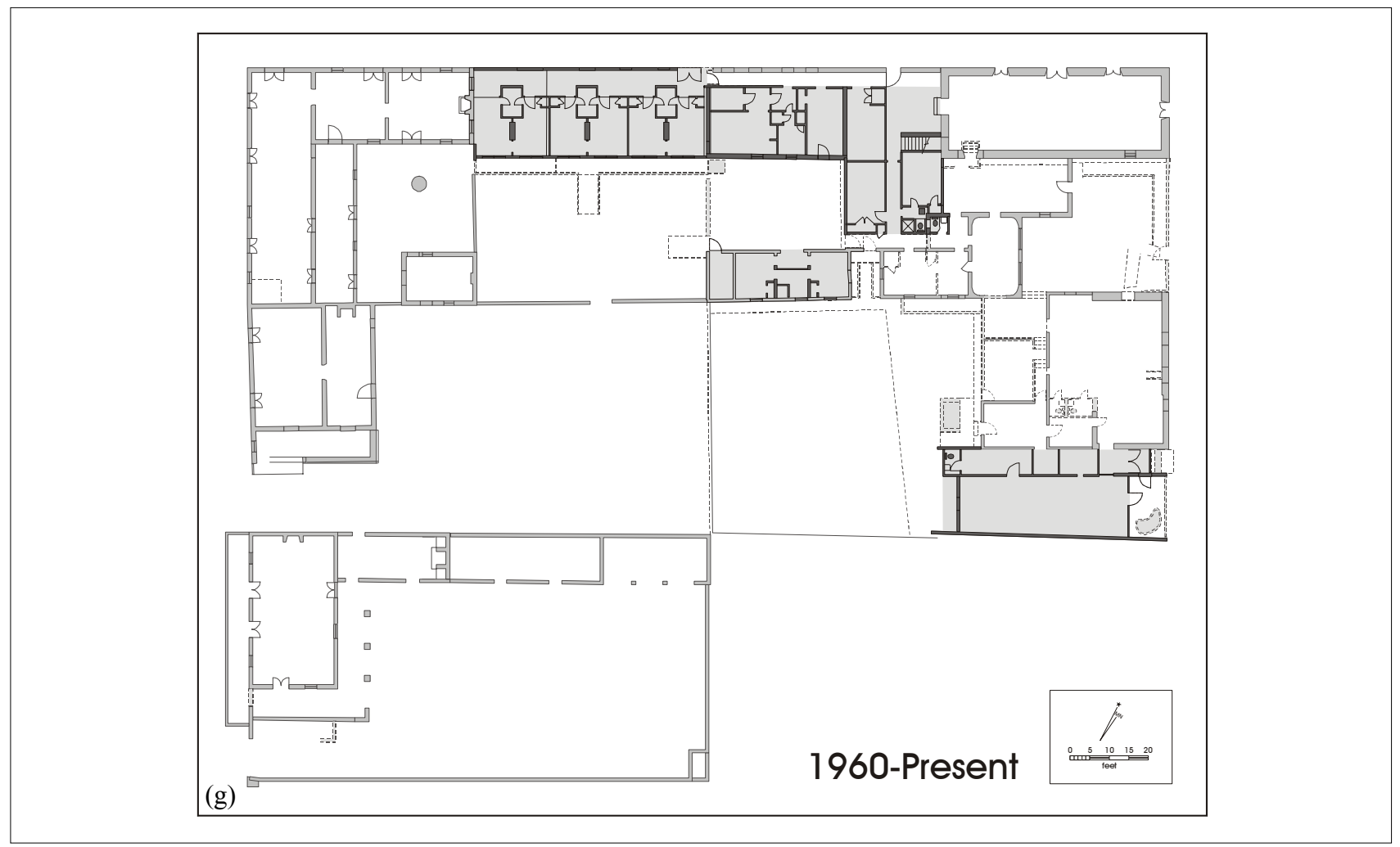

Figure 2-3. Sequence of construction continued...(g) 1960-Present.

\section{The Rafael García-Ramirez House and Store (41SR2 12)}

This site is located on Lot 1 of Block 8 . The original structure, built circa 1870, overlooks Portscheller Street (Figure 2-5). The building has a one-story rectangular plan that measures approximately 17.5 by 61 feet and was divided into two rooms at one time. The walls are brick masonry that is painted on the exterior and plastered on the interior. Its roof is framed with hand-hewn joists that support concrete and brick tile roofing. A detached one-story rectangular plan kitchen, measuring approximately 13.5 by 19 feet, is located along the south property line behind (to the north of) the original building. The kitchen floor is concrete while the original roofing appears to have consisted of wood shingles. The brick-paved courtyard in front of the kitchen contains a brick-lined cistern. The kitchen and cistern may have been among the earliest additions to the site. The second addition is a one-story rectangular plan structure measuring approximately 21 by 41 feet, overlooking the plaza. It has brick masonry walls, parapets, and a roof framed with dressed wood joists supporting concrete and brick tile roofing. By 1894, based on Sanborn maps, a wooden porch was attached to the back of the original structure. Several additions have been built primarily along the northern and eastern property lines between 1894 and the 1960s.

\section{The Ramirez Hospital (41SR2 15)}

The Ramirez Hospital is located on Lot 8 of Block 8, on the corner of the plaza and Estrella Street (Figure 2-6a). In addition to being a part of the Roma Historic District National Historic Landmark (1993), it is a Registered Texas Historic Landmark (1965). This building is two stories, constructed of sandstone rubble (Figure 2-6b). The date of construction is not known. The plaque designating it a Registered Texas Historic Landmark states it was built in 1853, but there is no direct evidence for this in the deed records (Zapata 2002:57). When the lot was sold in 1849, the deed mentions buildings but it is not known if the building currently on the site was one of them (Zapata 2002:57). The current building was certainly built by 1894 (see Figure 2-1). 


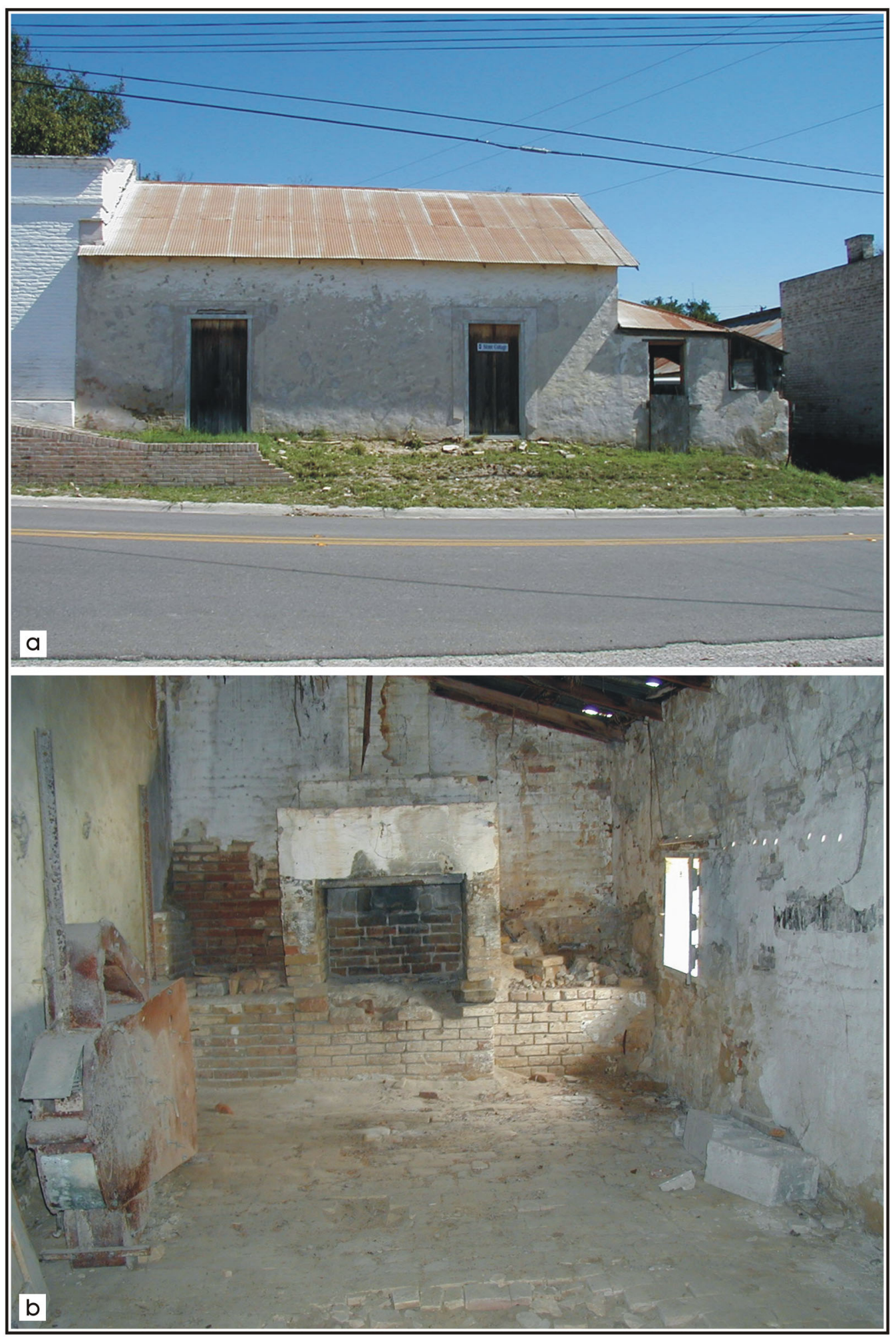

Figure 2-4. The Stone Cottage (41SR211), February 2003. (a) front of cottage facing Portscheller Street; (b) interior of the addition with kitchen fireplace. 


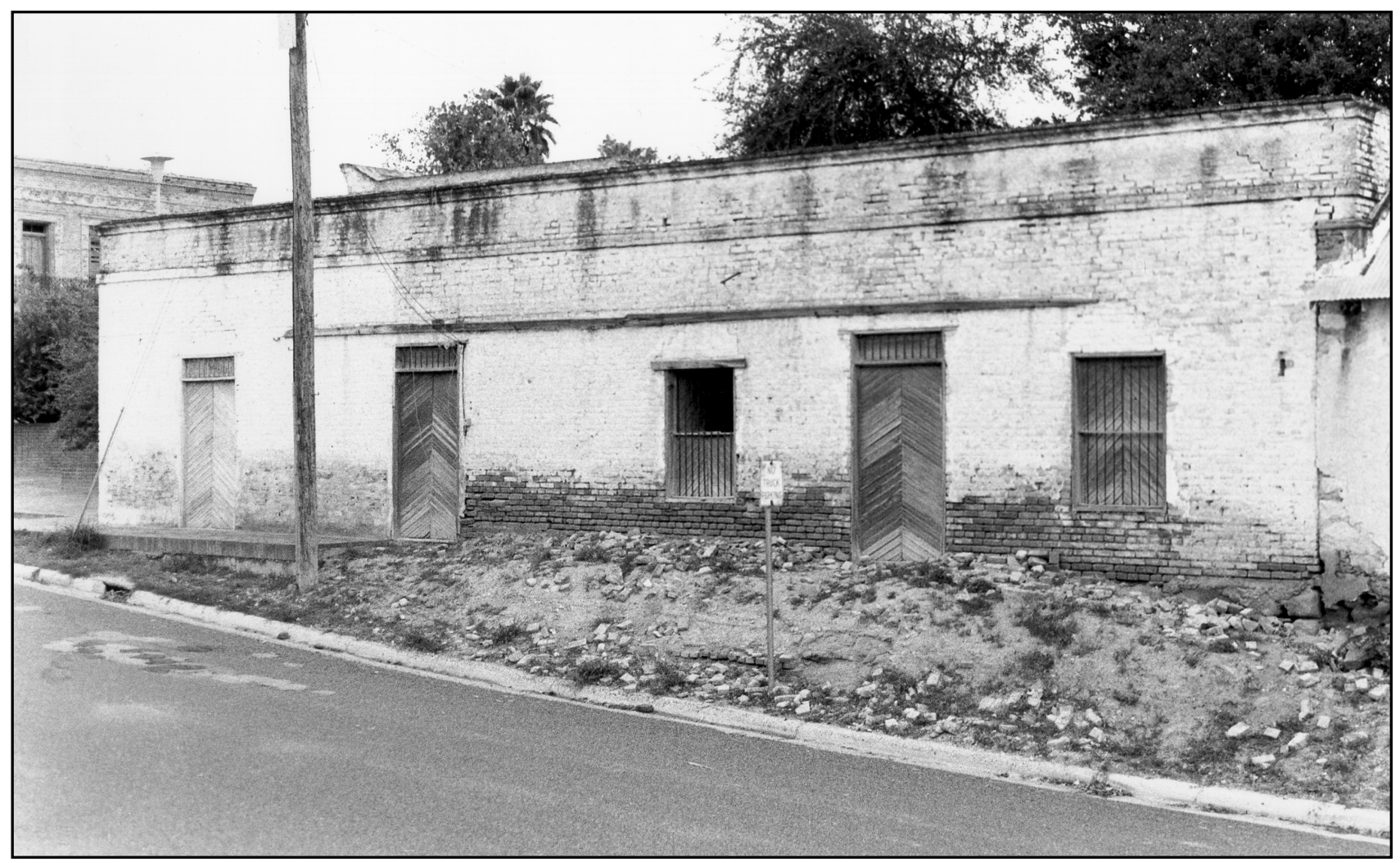

Figure 2-5. The Rafael Garcia-Ramirez House and Store (41SR212).

The structure served as a military headquarters during the Civil War. In 1911, it was sold to Genaro Madrigal who used it as a residence until 1957 when it was purchased by Dr. Mario Ramirez, who modified the building into a hospital. The original building is a two-story rectangular plan measuring approximately 23.5 by 59 feet. It has parapets, wood roof framing, and concrete and brick tile roofing. The walls are stuccoed stone masonry with painted brick cornices on the north and east facades. A continuous cast iron balcony appears to have wrapped around these same facades. The first and second floor floorings are 1-x4-inch tongue-and-groove wood with 2-x-6-inch wood sleepers resting on brick footers. Masonry openings are spanned with hand-hewn mesquite lintels. Interior walls are finished in plaster and painted. Original access to the second floor may have been through outside stairs running along the south wall.
Numerous one-story rooms have been added to the original building. Some of the earliest ones appear on 1894 Sanborn maps, others are visible on 1925 Sanborn maps, while still other additions were not completed until the late 1950s or early 1960s. The first of these additions shows up on 1894 Sanborn maps as two one-story rectangular plan sheds (13 by 25 feet each) built west of the original structure. By 1894 , a rectangular plan frame shed (11 by 15 feet) also was added adjoining the south property line at the back of the property. A second rectangular plan shed was added adjoining the one along the south property line soon thereafter. Four additional buildings were added to the original structure between 1895 and 1960, for a total of seven additions. At least four of these additions are non-extant or only partially extant. The Ramirez Hospital has been stabilized on the exterior and is currently an attractive addition to the plaza. The interior is still in need of extensive restoration (Figure 2-6c). 

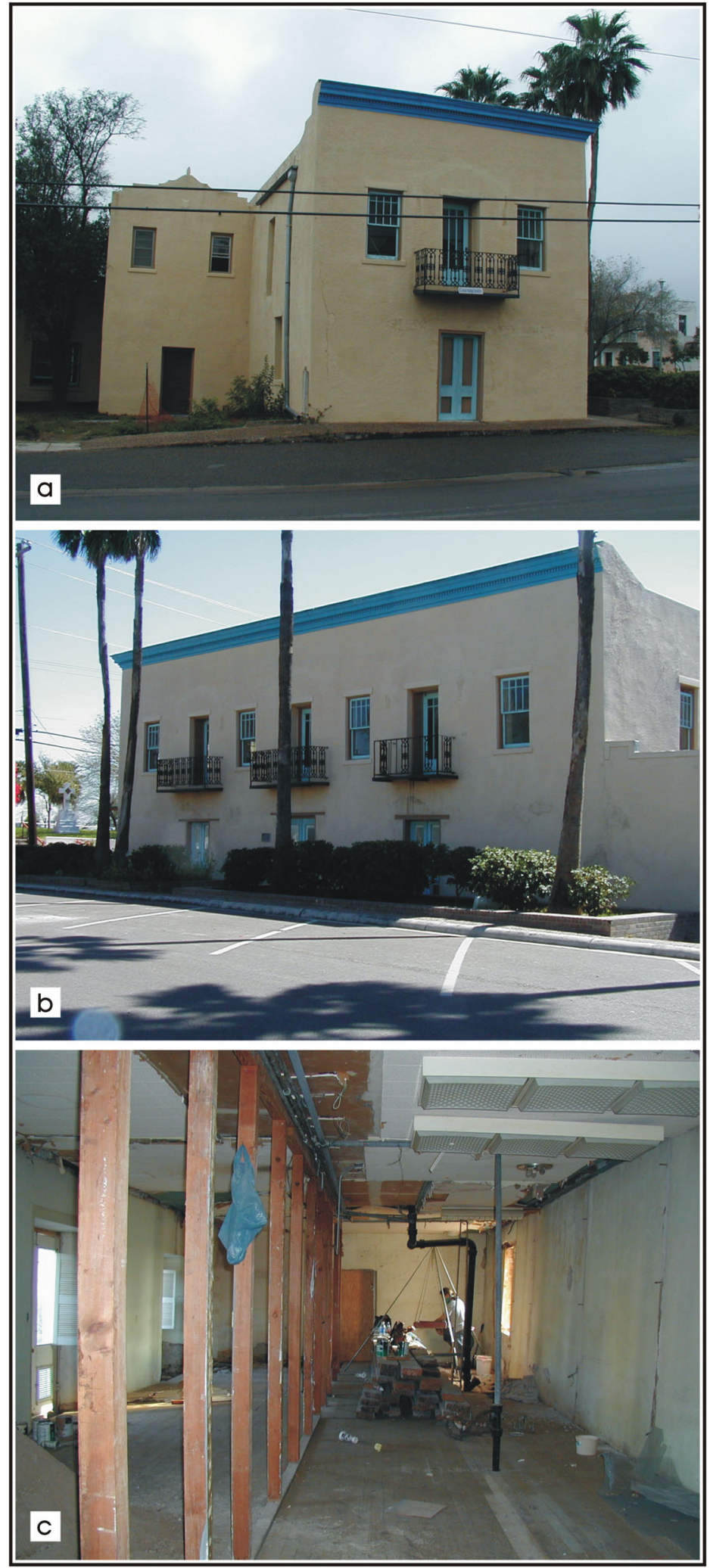

Figure 2-6. The Ramirez Hospital (41SR215). (a) exterior facing Estrella Street; (b) exterior facing the plaza; (c) interior room. 


\section{The Coffee Pot Café Site (41SR337)}

The Coffee Pot Café site is named for the last business to occupy the building (Figure 2-7). It is believed that the original structure on Block 8, Lot 7, was located at the north corner of the lot (see Figure 1-2). The northern corner of the main room of the Café building is the only part of the building made of sandstone rubble, and is thus believed to date prior to the 1860 s, since by then most buildings in Roma were being built of brick. Various extensions were added to the original structure after 1894.

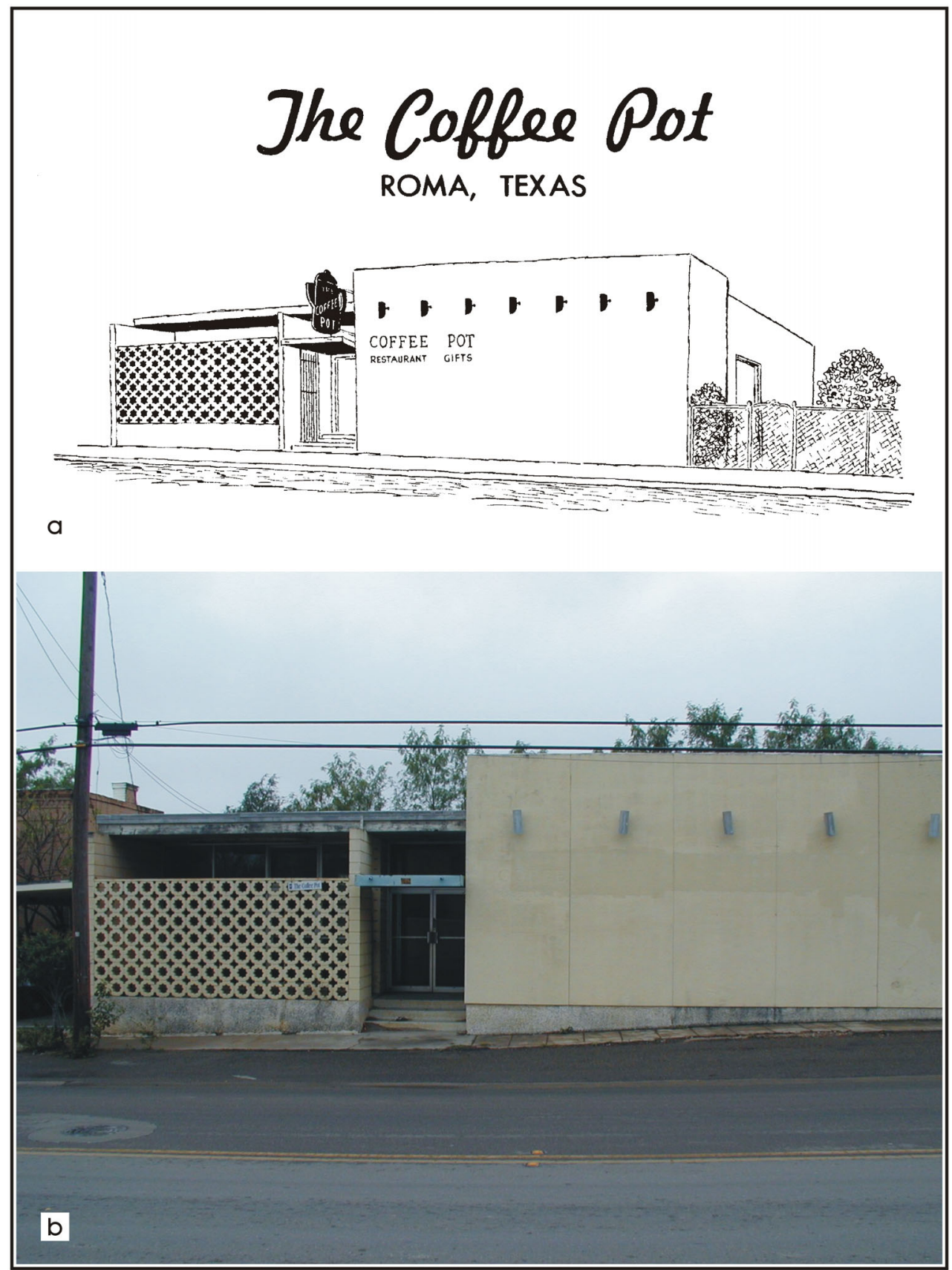

Figure 2-7. The Coffee Pot Café (41SR337). 


\section{Previous Investigations}

Between June 15 and August 20, 1976, the Texas Historical Commission carried out a historical and archeological investigation in the Roma Historic District (O'Malley et al. 1976). This included historical research, surface collections in the plaza northwest of the current project area, recording of the older brick sidewalks or banquetas and retaining walls, and two backhoe trenches dug near the International Bridge (O'Malley et al. 1976). The artifacts from the surface collection in the plaza dated from the nineteenth century to the time of the survey.

Between July 1993 and May 1997, excavations were carried out by José E. Zapata for the Roma Restoration Project sponsored by the Texas Parks and Wildlife Department (Fox et al. n.d.; Zapata 2002). The principal goal of the project was architectural preservation and restoration of a group of buildings within the core of the Roma Historic District. Archeological testing and monitoring concentrated on details of construction and, wherever possible, the history of the original building and subsequent additions and changes. Three sites included in the current project area were excavated by Zapata (Fox et al. n.d.): the Antonia Sáenz House (41SR210), the Stone Cottage (41SR211), and the García-Ramirez House and Store (41SR212). Figure 2-8 shows the location of Zapata's excavations in these three sites (Fox et al. n.d.).

As a result of Zapata's excavations, large numbers of artifacts, dating from the nineteenth through the late twentieth centuries, were recovered (Fox et al. n.d.). Of particular interest was the large number of artifacts in Zapata's Unit 2 at 41SR210, the Antonia Sáenz House. Although this house was built in the 1870 s, many of the artifacts from an apparent trash midden in Unit 2, located outside the back door of the house (Figure 2-8), predate the structure. In addition, the midden feature appeared to penetrate under the building foundation, suggesting that its excavation predated the construction of the structure (Fox et al. n.d.). Finally, the presence of the possible trash midden containing material culture dating to the period of the founding of the city suggested that other pits also may be encountered containing artifacts dating to the earliest days of the city. 


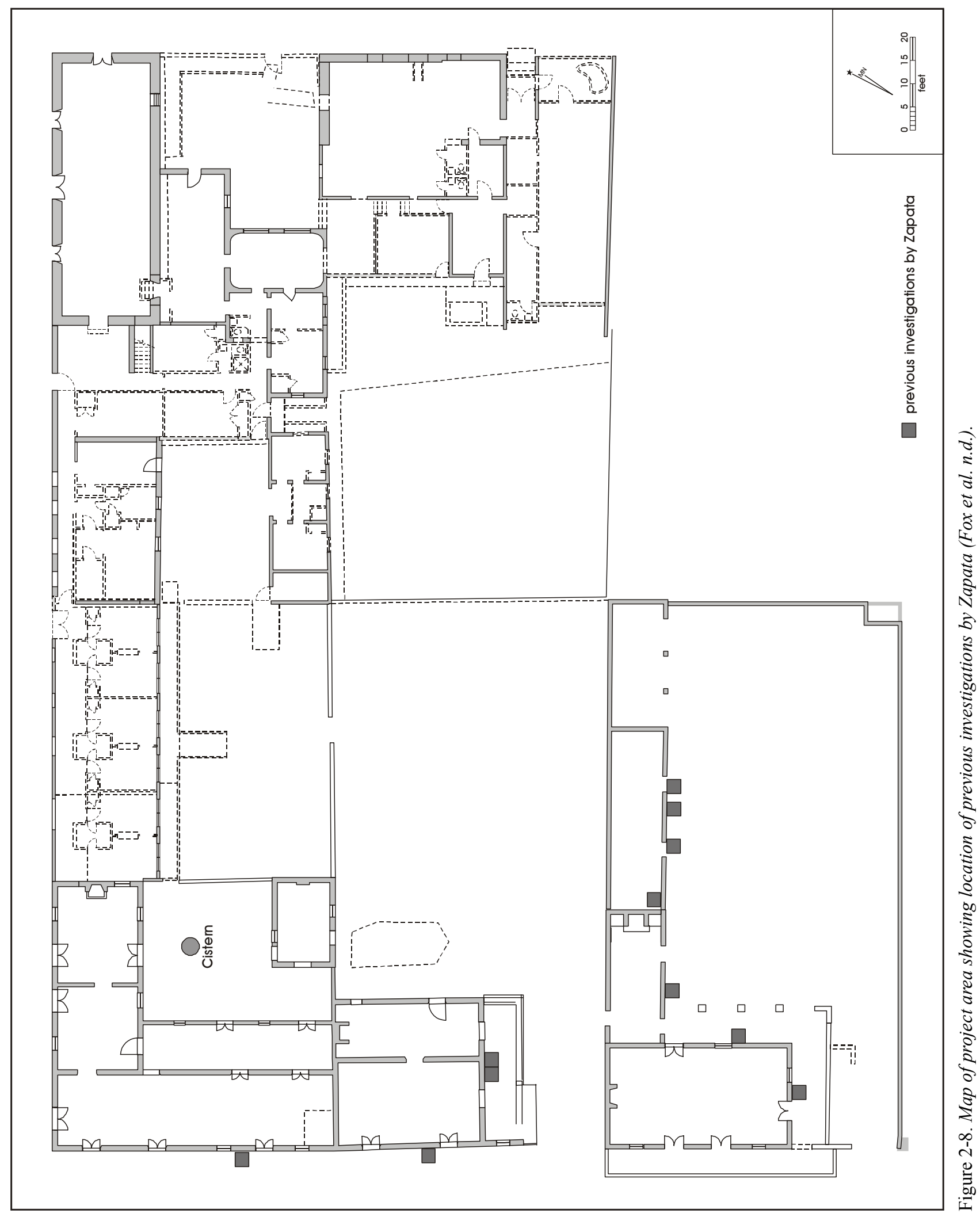




\section{Chapter 3: Levels and Methods of Investigation}

The town of Roma was established in August 1848. Therefore, the period of significance of the National Historic Landmark begins with its establishment and does not at present include earlier materials/deposits. Furthermore, the previously referenced Roma Restoration Project has already characterized the ages of the archeological deposits contained within the properties contributing to the National Historic Landmark and has investigated the post 1850s contributing components of the National Historic Landmark. Because work on the report of findings of the RRP was suspended soon after the fieldwork ended, the production of a final report became a concern only after the funding of the Roma Visitor Complex project. Because the final report of findings of the RRP had not been published at the time of the discussion of the scope of archeological services associated with the RVC project, the Texas Historical Commission, TxDOT, and Kell Muñoz Architects were informed by CAR in a series of meetings about the findings of the RRP. Therefore, the tasks, as well as the scope of archeological investigations associated with the RVC project requested by the Texas Historical Commission were based on these initial findings of the RRP.

Nonetheless, because the RRP concentrated heavily on the investigation of post-1850s contributing properties within the National Historic Landmark District and also identified areas within the National Historic Landmark where deposits dating to around 1850 may be found, in a meeting between the Texas Historical Commission, TxDOT, and CAR in October 2002, it was decided that the focus of archeological services would be to identify any buried archeological deposits, to collect information in order to evaluate the National Register-eligibility of those deposits, and to make a recommendation whether the proposed project would impact such deposits and what further work was warranted.

As noted in the individual site histories, structures built in the 1850 s are not present within all of the five sites. Furthermore, the work conducted by Zapata as part of the RRP identified only one location within the National Historic Landmark, the Antonia Sáenz House (41SR210), where undisturbed deposits dating to circa 1850 may be found. Nonetheless, during the RRP, subsurface investigations were limited to only three of five properties concerned here: the Antonia Sáenz House, the Stone Cottage, and the Rafael
García-Ramirez House and Store (see Figure 2-8). No archeological investigations were undertaken in the Ramirez Hospital site and The Coffee Pot Café site and no subsurface excavations were preformed in the courtyards of either the Stone Cottage or The Coffee Pot Café. Therefore, the results of the RRP work left open the possibility that cultural deposits dating to the original founding of the City of Roma may be found buried in hitherto unexplored portions of the National Historic Landmark. With these concerns and parameters in mind, the archeological services and methods of investigation varied between properties.

\section{Levels of Investigation}

No excavations were planned within the structures at 41SR210, the Antonia Sáenz House, because there were no known construction episodes dating to the 1850s. However, because Unit 2 excavated by Zapata during the RRP did identify deposits pre-dating the construction of the original structure (1884), it was decided that an adjoining unit would be hand excavated to further explore the trash midden and the age of the deposits (see Figure 1-4). In addition, monitoring was required for the excavation of a geotechnical test pit outside of the front of the building facing Portscheller Street and of a hand-auger bore within the center of the floor of the original structure at the site.

At 41SR211, the Stone Cottage, the original structure was built around 1850, therefore a hand-excavated unit was planned in its southeast corner. Although the kitchen addition may have been built between 1870 and 1880 , because of the similar construction style and materials it was decided that a unit would be excavated within this structure as well (see Figure 1-4). CAR staff also monitored the excavation of a geotechnical test pit in front of the building on Portscheller Street and a concrete core and hand-auger bore through the floor of the original building.

At 41SR212, the Rafael García-Ramirez House and Store, there are no building episodes and structures dating to around 1850. Therefore, CAR staff focused on monitoring two geotechnical pits excavated in two of the structures of the site, and a hand-auger bore in the original main building (see Figure 1-4). 
At 41SR215, the Ramirez Hospital, the original structure was constructed during the 1850s, therefore, CAR staff excavated two test units within this structure-one in the northeast corner and the other in the southwest corner (see Figure 1-4). An archeologist also monitored the excavation of the geotechnical test pits, one along the back (south) wall of the original structure and one along the outside wall of an addition that appears on an 1894 Sanborn map. A handauger bore, excavated in the center of the floor of the original structure, was also monitored by CAR staff.

At 41SR337, The Coffee Pot Café, no sub-floor disturbances were planned in the original structure of this site. However, the slab floor of a small structure immediately west of the Café was to be removed. Because it is unclear exactly when the structures on this site were erected, in concurrence with the Texas Historical Commission and TxDOT, it was decided that a hand-excavated unit would be excavated beneath the slab to check for circa 1850 s deposits within the site. In addition, the excavation of three geotechnical test pits was monitored by CAR staff. Two of these were dug behind the original structure on the site, while the third was along the outside wall (see Figure 1-4). Finally, a concrete core and hand-auger bore drilled/dug through the floor of the original structure were also monitored.

In order to accomplish the tasks outlined in the scope of work, CAR staff also planned to dig 36 shovel tests on a 5-m grid across the southern part of the courtyard, between the Stone Cottage (41SR211) and The Coffee Pot Café (41SR337), to determine if there was evidence of trash deposits from the early nineteenth century or significant architectural remains in the area. Two test units were subsequently excavated by CAR staff to investigate subsurface debris concentrations identified during shovel testing (see Figure 1-4).

\section{Methods of Investigation}

\section{Test Units}

The eight 1-x-1-m hand-excavated units were dug in 10-cm arbitrary levels unless clearly isolable natural depositional zones were identified. When encountered, natural depositional zones were dug in $10-\mathrm{cm}$ or thinner layers making sure that each zone was kept separate. In retrospect, given the possibility that the buried deposits of the National Historic Landmark may contain multiple thin veneers of cultural materials, $5-\mathrm{cm}$ arbitrary excavations levels could also have been employed during the excavations. All matrix was screened through $1 / 4$-inch hardware cloth and all artifacts were collected for analysis. Observations on the excavation levels (i.e., content, soil characteristics, integrity of deposits) were recorded on standardized excavation level forms. Because lighting varied from bright sunlight to barely light enough to see to work, small soil samples ( 4 by 4 inches) were taken from each level. After return to the lab, samples were air-dried and the color of each was identified using a Munsell chart in consistent lighting.

All units were dug through at least one, and usually two, sterile levels before terminating excavation. The only exception to this was Test Unit 8, which was terminated at $120 \mathrm{~cm}$ below datum (cmbd), because of safety concerns.

\section{Shovel Tests}

A total of 36 shovel tests was dug on a 5-m grid across the courtyard between the Stone Cottage (41SR211) and The Coffee Pot Café (41SR337). The shovel tests were excavated in arbitrary $10-\mathrm{cm}$ levels to a depth of $70 \mathrm{~cm}$ below surface (cmbs), unless an obstacle such as concrete or utility lines (ceramic and/or cast iron pipes) was encountered above this depth. Matrix from these tests was screened through $1 / 4$-inch mesh, all artifacts were collected, and observations on the shovel tests were written on standardized forms, including description of soil texture, inclusions (such as gravel), and types of artifacts recovered. Units and walls within units with distinctive stratigraphic zones were profiled at the end of the excavations. Because lighting varied considerably during fieldwork, small soil samples were taken from each level. After return to the lab, the samples were air-dried and the color of each was identified using a Munsell chart in consistent lighting.

\section{Monitoring}

The monitoring of the bore holes ( 3 inches and 9 inches in diameter) dug by Petroleum Solutions, Inc. (PSI) in several locations across the project area did not occur because these bore holes had already been dug by the time the CAR crew arrived in Roma. The crew did, however, examine the area around each of these bore holes, but did not see any artifacts.

The excavation of the nine geotechnical test pits was carried out by PSI employees using shovels. During the excavation in and around the buildings in the project area, a CAR staff archeologist was present. During most of this part of the 
project, two test pits were being dug simultaneously. The archeologist moved between active units, noting sediments, architectural features and artifacts. Photographs were taken when each test pit was completed. The scope of work stated that the testing would be stopped only if significant numbers of early-nineteenth-century artifacts were noted.

\section{Laboratory Methods}

Artifact bags were returned to the CAR laboratory at the end of fieldwork. Artifacts were washed in tap water and air-dried. Artifacts were then cataloged in general categories (e.g., ceramics, glass, clothing items, personal items, etc.). Individual categories were then analyzed by specific attributes designed for each group. All data was entered into a Microsoft Access database.

All cultural materials to be curated were prepared in accordance with federal regulation $36 \mathrm{CFR}$ part 79 . Artifacts were placed by analysis category in archival-quality plastic bags with acid-free paper labels containing a provenience and corresponding lot number. They were then boxed by class in acid-free boxes labeled with standard labels.

Field notes, forms, photographs, and drawings were placed in labeled notebooks. Photographs, slides, and negatives were placed in archival-quality sleeves. All notebooks are stored in acid-free boxes. Documents and forms are printed on acid-free paper. A copy of the testing report and all computer disks pertaining to the investigations are curated with the field notes and documents. All artifacts and projectrelated documents are permanently curated at CAR .

\section{Analysis Methods}

Establishing the age of the deposits was one of the main goals of the analysis of the materials recovered from the five sites. To accomplish this, diagnostic artifact types were grouped into one of the following four date groupings:

Eighteenth to Early Nineteenth Century: This group includes such artifacts as unglazed ceramics, lead-glazed ceramics, Colonial period majolica, edge decorated or handpainted white earthenwares, dark olive ("black") glass and olive glass, and handmade bricks. All lithic materials are placed in this age category, although there is no indirect way of establishing whether the lithic artifacts derive from the late eighteenth century or continued to be manufactured into the early to mid-nineteenth century.
Nineteenth Century: This group includes artifacts used throughout the nineteenth century, such as most white earthenwares, including undecorated, annular, sponge, transfer and flow blue decorated, stoneware, yellow ware, cut nails, handmade shell buttons, and lamp chimney glass.

Late Nineteenth to Early Twentieth Century: This period marks the beginning of the Industrial Age in Texas. Artifacts from this period include machine-made buttons (both metal and shell), ceramic doll fragments, "purpled" or sun-colored clear glass, and an assortment of other items such as ceramic doorknobs, etc.

Twentieth Century: This group includes such items as wire nails, machine-made bottles, and most types of plastic.

These artifact groupings are not based on absolute dating in most cases. We know, for example, that Puebla Blue-onWhite II majolica dates from 1740 to 1810 (Fox et al. 1997). But dating for most artifacts is not so well known. For instance, the type of thin-walled, lead-glazed ceramic known as Galera ware is usually considered to date to the Colonial period, although it continued to be used, in much smaller amounts, well into the nineteenth century, and is still being made in Mexico for the tourist trade (Fox 2002:207). However, since Galera ware was by far most commonly used during the eighteenth and early nineteenth centuries, it is included in that category. Another example is seen in certain shades of olive to brown-olive glass that was in use from the Colonial period and was still used occasionally until the $1850 \mathrm{~s}$ or 1860s. The use of those colors was by far the most common in the eighteenth and early nineteenth centuries. Similarly, although some undecorated white earthenwares are probably undecorated parts of otherwise decorated items, such as edge decorated plates from the early nineteenth century, this artifact type is placed in the more general Nineteenth Century category, both because most types of white earthenwares were in use during much of the nineteenth century and because completely undecorated white earthenwares were most popular at the end of the nineteenth century.

The majority of artifacts cannot be limited to only one of the categories above. Such artifacts include most colors of glass, including most clear glass. There was little if any clear glass made in the United States before 1840 (Kendrick 1967:21) but some clear glassware was being made in Puebla from the 1540s through the nineteenth century (Deagan 1987:129-130), so clear glass cannot be used for dating, unless the color of the glass has changed due to the addition 
of one of the chemicals used to de-colorize glass. These chemicals change its color when exposed to sunlight for extended lengths of time. There are two types of clear glass made with these chemicals: manganese, which dates from circa 1880 to 1915, and turns purple after extended exposure to sunlight (Munsey 1970:55-56); and selenium, which dates from 1915 to about 1930, and turns glass a pale amber yellow after exposure to sunlight (Munsey 1970:55-56).

Bone and mussel shell also cannot be dated with accuracy, except by association with other artifacts. In this report, bone will be included in the non-diagnostic artifact category.

Although these broad temporal diagnostics are very useful in determining the age and degree of disturbance of buried deposits, it is difficult to equate percentages of diagnostics from different age categories (i.e., decades) as necessarily correlating with degree of disturbance of deposits. This is in part the case because the use-life of artifacts varies and the degree of recycling and reuse of artifacts may also vary between cultures and social classes. In addition, the terminal use of certain artifact classes such as gun flints and stone tools is not well established and likely varied in different parts of the state depending on factors such as access to commodities, interaction with nearby missions, and wealth. Finally, different site maintenance and discard behaviors will contribute different ratios and mixes of diagnostic artifacts to an archeological deposit depending on whether interior and extra-mural surfaces are being maintained. These systemic factors in combination with post-depositional disturbances that also tend to impact buried deposits create a complex challenge when it comes to the cross-dating of archeological deposits. For instance, depending on how late flintlock guns were in use, the presence of gun flints in deposits also containing majolica and undecorated native wares (Goliad wares) mixed with edge decorated or handpainted white earthenwares may or may not indicate disturbed deposits. 


\section{Chapter 4: Results of Investigations}

Fieldwork took place between February 12 and March 4, 2003. When the CAR crew arrived at the site, they discovered that the bore holes mentioned in the scope of work had already been dug. Due to a holiday weekend that occurred during this period, concrete floors were not removed until late on February 18. Rather than waiting idle during this period, CAR personnel excavated two additional 1-x-1-m units near shovel tests in the courtyard of 41SR337 in order to further test an area where a concentration of artifacts had been identified. In addition, one CAR staff archeologist returned on March 4, 2003, for a day of monitoring test pits dug by PSI.

Eight 1-x-1-m test units and 36 shovel tests were excavated during this project. The results of these excavations are described on a site-by-site basis. Tables 4-1 through 4-10 list the artifacts recovered from the test units. Individual artifacts of particular interest are also described.

\section{The Antonia Sáenz House (41SR2 10)}

\section{Test Unit 1}

As mentioned in Chapter 1, during excavations in 1993 1997, Zapata dug a unit just south of the back door of the Sáenz House (Fox et al. n.d.). While the construction date of the original building is circa 1870-1880, Zapata identified a possible refuse midden just outside the back door that contained artifacts that clearly predated the building date (Fox et al. n.d.). To further investigate the age of the midden and its relationship to the later structure, a 1-x-1-m test unit was dug near Zapata's unit. Designated Test Unit 1 (TU 1), this unit was placed against the back wall, 1 m north of the southeast corner of the Sáenz house (Figures 4-1 and 4-2). The vertical datum was placed on the west corner of the unit, $5 \mathrm{~cm}$ above ground level.

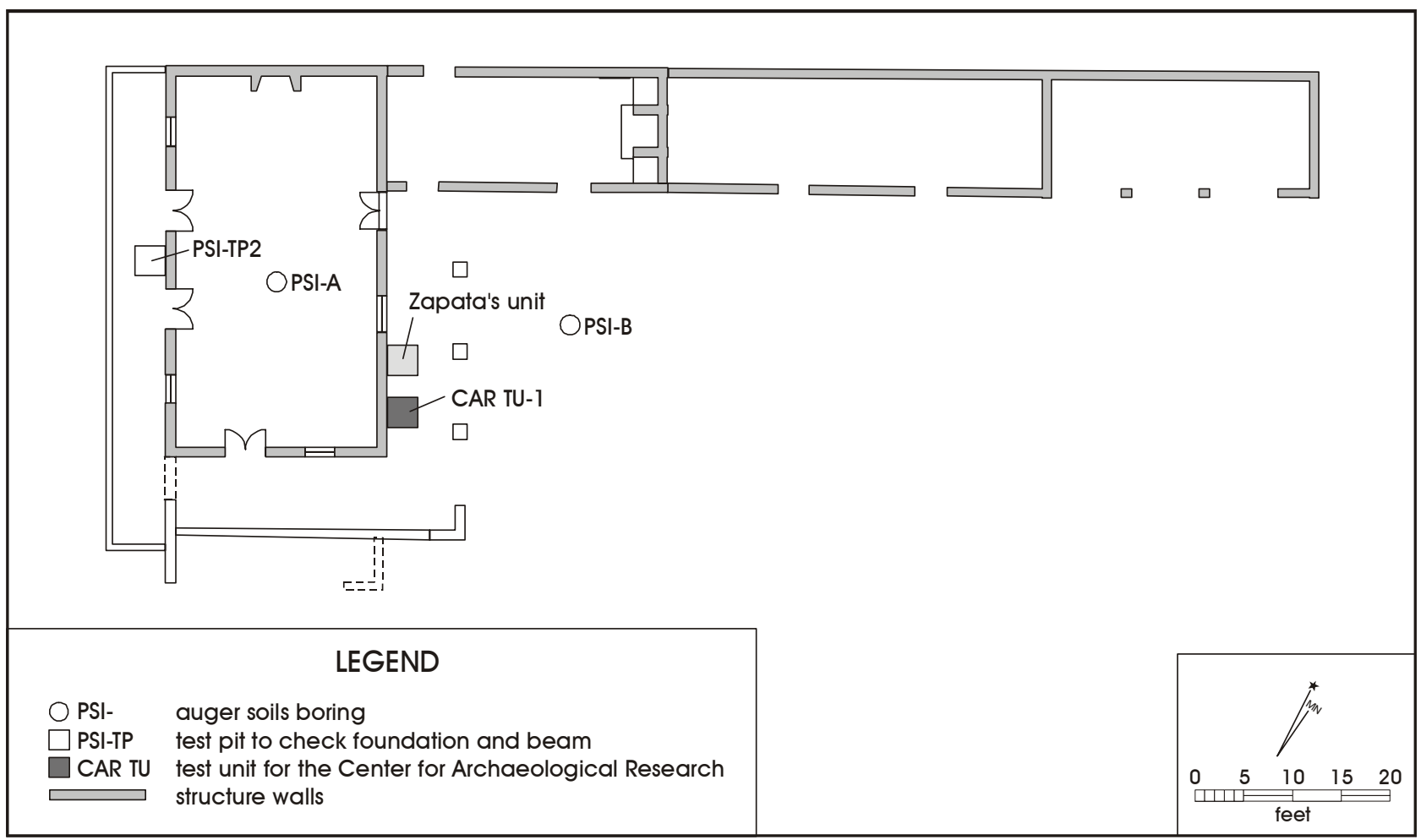

Figure 4-1. Plan of the Antonia Sáenz House (41SR210), showing location of Test Unit 1, Zapata's unit, and test pits dug by PSI. 


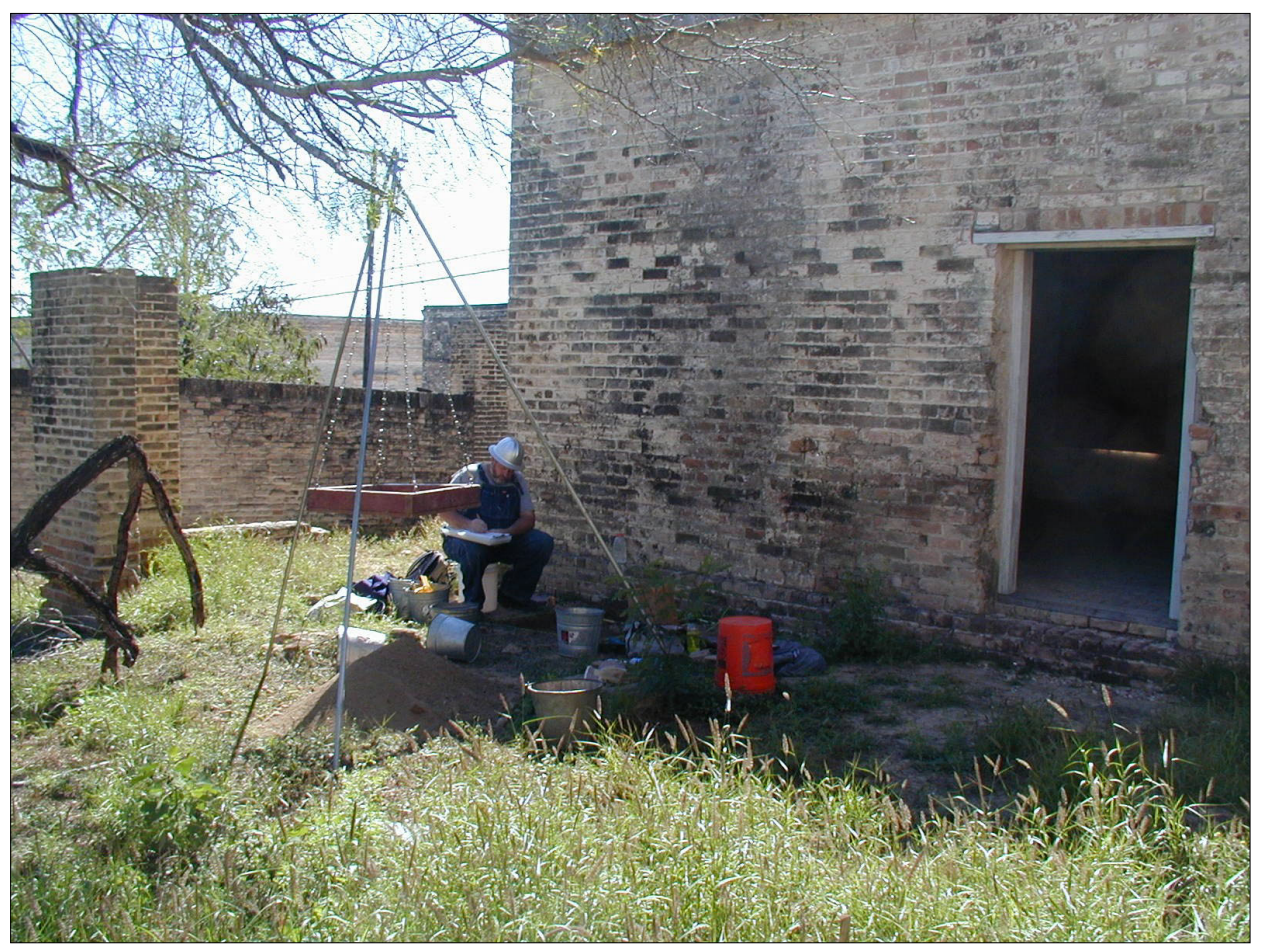

Figure 4-2. Excavation of Test Unit 1 (41SR210), facing south.

The upper layer of TU 1 was composed of a very loose grayish-brown sandy clay loam. After the first few centimeters, a large number of both reddish and yellowish handmade bricks and large sandstone rocks were encountered, confined for the most part to the northern half of the unit. Diagnostic artifacts from the upper $10 \mathrm{~cm}$ were evenly mixed between eighteenth, nineteenth, and twentiethcentury materials (Table 4-1).

At about 20-22 cmbd, sediments in the northern half of the unit became harder and much more compact. The sediments in the southern half were softer, and appeared to be both darker and moister. A distinct edge to the hard-packed graybrown sediments was noted, running across the unit in a roughly east-west orientation, that appeared to form the edge of a pit. For both Level 4 (30-40 cmbd) and Level 5 (40-50 $\mathrm{cmbd}$ ), artifacts from the southern half of the unit, believed to be from a pit feature, were designated Level $4 \mathrm{a}$ and Level $5 \mathrm{a}$, while artifacts from the northern half were designated Level $4 b$ and Level $5 b$ (see Table 4-1). When excavation of Level 4a was completed, the pit was clearly visible (Figure 4-3). The edge of the pit sloped to the southeast. At the bottom of Level 5, only a small portion of the pit was still visible in the southern wall of the unit. Beginning with Level
6 , the entire unit was dug as a single level; however, a slight distinction between the northern two-thirds and the southern one-third of the unit could still be seen. The southern onethird was somewhat sandier and had a slightly darker color.

A 2-cm-thick lens of charcoal and burned gravel, about 30$40 \mathrm{~cm}$ in diameter, was encountered at about $52 \mathrm{cmbd}$ against the wall of the building, It appeared similar to a charcoal lens described by Zapata in the unit he excavated to the north of TU 1 (Fox et al. n.d.). The burning appears to have happened after the foundation was constructed, as the stones of the foundation are stained at this location.

This slight difference in sediments was still noted at the top of Level 7 (60-70 cmbd), but was only found in the southern $20 \mathrm{~cm}$ or so of the unit. Near the top of the level, in the northern two-thirds, large numbers of pea gravels were encountered. The area of slightly darker and sandier sediments in the southern part of the unit grew smaller as the depth approached $70 \mathrm{cmbd}$; at the bottom of this level only about $5 \mathrm{~cm}$ of the southeastern wall of the unit still had this type of sediment. As excavation continued, the pea gravels covered the entire unit. Large sandstone rocks $(7-15 \mathrm{~cm}$ in size) became very numerous again and the only 
Table 4-1. Artifacts recovered from Test Unit 1, 41SR210

\begin{tabular}{|c|c|c|c|c|c|c|c|c|c|c|c|c|}
\hline $\begin{array}{c}\text { Approximate } \\
\text { Dates }\end{array}$ & Artifact Types & 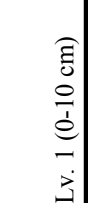 & 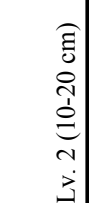 & 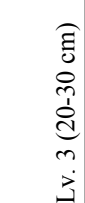 & 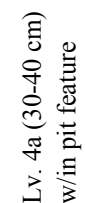 & 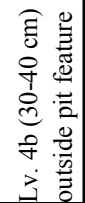 & 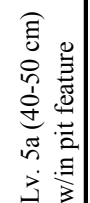 & 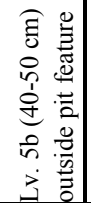 & $\begin{array}{l}\text { శ్ } \\
0 \\
0 \\
0 \\
0 \\
0 \\
0 \\
0 \\
\dot{3}\end{array}$ & 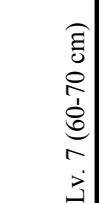 & 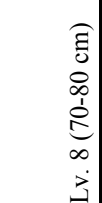 & हैं \\
\hline \multirow{16}{*}{$\begin{array}{l}\text { 18th to Early } \\
19 \text { th Century }\end{array}$} & Debitage & 1 & 11 & 0 & 1 & 1 & 5 & 11 & 14 & 17 & 4 & 65 \\
\hline & Core & & & & & & & & & 1 & & 1 \\
\hline & Biface & & & & & & & & & 1 & & 1 \\
\hline & Unglazed (Unrefined) ceramics & 1 & & 1 & & & & 9 & 4 & & & 16 \\
\hline & Unglazed burnished ceramics & & & & & 1 & 1 & 2 & & & & 4 \\
\hline & Tonalá Burnished Ware & 1 & & & 1 & & & & & & & 2 \\
\hline & Tin glazed: Puebla Blue on White II & & & & & & & 1 & & & & 1 \\
\hline & Lead glazed-Sandy paste ware & 1 & 4 & 3 & & 3 & 3 & 8 & & & & 22 \\
\hline & Lead glazed-Unidentified & & 1 & & & & & & & & & 1 \\
\hline & Lead glazed-Galera & & & & & 1 & & 2 & & & & 3 \\
\hline & White earthenware (Edge decorated) & & & & & & & & 1 & & & 1 \\
\hline & White earthenware (Handpainted) & & 2 & 2 & & 2 & & 3 & 2 & & & 11 \\
\hline & Glass: Olive & 6 & 3 & 3 & 4 & 7 & 1 & 13 & 3 & 2 & & 42 \\
\hline & Brick, handmade & 14 & 48 & 12 & 2 & 6 & 5 & 5 & 5 & & & 97 \\
\hline & Total 18th to Early 19th & 24 & 69 & 21 & 9 & 21 & 15 & 54 & 29 & 21 & 4 & 267 \\
\hline & $\%$ of Diagnostic Artifacts in Level & $28.2 \%$ & $75.0 \%$ & $48.8 \%$ & $52.9 \%$ & $52.5 \%$ & $50.0 \%$ & $57.4 \%$ & $80.6 \%$ & $100.0 \%$ & $100.0 \%$ & \\
\hline \multirow{14}{*}{ 19th Century } & White earthenware (Unidentified) & & & 1 & & & & 2 & & & & 3 \\
\hline & White earthenware (Undecorated) & 11 & 7 & 7 & 3 & 8 & 3 & 15 & 2 & & & 56 \\
\hline & White earthenware (Sponge) & & & 1 & & & & 1 & & & & 2 \\
\hline & White earthenware (Annular) & 2 & & 2 & & & 3 & 4 & & & & 11 \\
\hline & White earthenware (Transfer) & & & & & & & 1 & 1 & & & 2 \\
\hline & White earthenware (Flow blue) & & & & & & & 2 & 1 & & & 3 \\
\hline & Stoneware & 1 & & & & 1 & & 1 & & & & 3 \\
\hline & \begin{tabular}{|l} 
Yellow ware \\
\end{tabular} & 1 & & 1 & & & & & & & & 2 \\
\hline & Glass: Dark olive ("black") & 2 & 5 & 6 & 3 & 3 & 4 & 7 & 2 & & & 32 \\
\hline & Lamp chimney glass & 7 & 3 & & & 1 & & 2 & & & & 13 \\
\hline & Clothing: Buttons: Hand made shell & & & 1 & & & & $\rightarrow$ & & & & 1 \\
\hline & Nails: Cut & 9 & 6 & 3 & & 3 & 5 & 5 & & & & 31 \\
\hline & Total 19th Century & 33 & 21 & 22 & 6 & 16 & 15 & 40 & 6 & 0 & 0 & 159 \\
\hline & $\%$ of Diagnostic Artifacts in Level & $38.8 \%$ & $22.8 \%$ & $51.2 \%$ & $35.3 \%$ & $40.0 \%$ & $50.0 \%$ & $42.6 \%$ & $16.7 \%$ & $0.0 \%$ & $0.0 \%$ & \\
\hline \multirow{8}{*}{$\begin{array}{l}\text { Late 19th to } \\
\text { Early 20th } \\
\text { Century }\end{array}$} & Glass: Clear (purpled) & 2 & & & & & & & & & & 2 \\
\hline & Clothing: Buttons: Machine made shell & 1 & & & & & & & & & & $\overline{1}$ \\
\hline & Ceramic doll fragments & 1 & & & & & & & & & & 1 \\
\hline & Casing: .32 cal. rimfired & & & & & 1 & & & & & & 1 \\
\hline & \begin{tabular}{|l|} 
Ceramic Doorknob \\
\end{tabular} & & & & 1 & & & & & & & 1 \\
\hline & Carbon battery rod & & 1 & & & & & & & & & 1 \\
\hline & \begin{tabular}{|l|} 
Total Late 19th to Early 20th \\
\end{tabular} & 4 & 1 & $\mathbf{0}$ & 1 & 1 & 0 & 0 & $\mathbf{0}$ & 0 & $\mathbf{0}$ & 7 \\
\hline & $\%$ of Diagnostic Artifacts in Level & $4.7 \%$ & $1.1 \%$ & $0.0 \%$ & $5.9 \%$ & $2.5 \%$ & $0.0 \%$ & $0.0 \%$ & $0.0 \%$ & $0.0 \%$ & $0.0 \%$ & \\
\hline \multirow{4}{*}{ 20th Century } & Crown caps & 1 & & & & & & & & & & 1 \\
\hline & Nails: Wire & 23 & 1 & & 1 & 2 & & & 1 & & & 28 \\
\hline & \begin{tabular}{|l} 
Total 20th Century \\
\end{tabular} & 24 & 1 & $\mathbf{0}$ & 1 & 2 & 0 & 0 & 1 & 0 & 0 & 29 \\
\hline & $\%$ of Diagnostic Artifacts in Level & $28.2 \%$ & $1.1 \%$ & $0.0 \%$ & $5.9 \%$ & $5.0 \%$ & $0.0 \%$ & $0.0 \%$ & $2.8 \%$ & $0.0 \%$ & $0.0 \%$ & \\
\hline \multicolumn{2}{|c|}{ Total Diagnostic Artifacts } & 85 & 92 & 43 & 17 & 40 & 30 & 94 & 36 & 21 & 4 & 462 \\
\hline
\end{tabular}


Table 4-1. continued...

\begin{tabular}{|c|c|c|c|c|c|c|c|c|c|c|c|c|}
\hline $\begin{array}{l}\text { Approximate } \\
\text { Dates }\end{array}$ & Artifact Types & $\begin{array}{c}\hat{0} \\
0 \\
0 \\
0 \\
0 \\
\dot{3} \\
\end{array}$ & 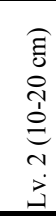 & 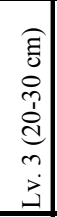 & 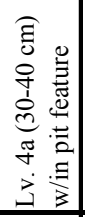 & 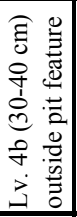 & 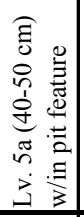 & 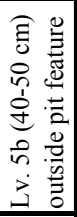 & $\begin{array}{l}\widehat{\Xi} \\
0 \\
0 \\
\vdots \\
0 \\
0 \\
\grave{3} \\
\end{array}$ & 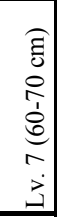 & $\begin{array}{c}\widehat{E} \\
0 \\
0 \\
\dot{1} \\
0 \\
\infty \\
\dot{3} \\
\end{array}$ & 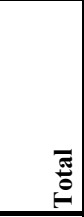 \\
\hline \multirow{21}{*}{$\begin{array}{c}\text { Non- } \\
\text { diagnostic }\end{array}$} & Porcelain & 1 & & & & & & 2 & & & & \\
\hline & $\begin{array}{l}\text { Glass:Brown } \\
\end{array}$ & 4 & 4 & 1 & 1 & & & & & 1 & & 11 \\
\hline & \begin{tabular}{|l|} 
Glass: Aqua \\
\end{tabular} & 24 & 1 & & & & & & & & & 38 \\
\hline & Glass: Light Blue & & & & & & & 2 & & & & 2 \\
\hline & \begin{tabular}{|l|} 
Glass: Clear \\
\end{tabular} & 40 & 10 & 5 & 4 & 4 & & 7 & & 1 & & 76 \\
\hline & \begin{tabular}{|l|} 
Window glass \\
\end{tabular} & 47 & 9 & & & 4 & 2 & 4 & & & & 69 \\
\hline & \begin{tabular}{|l} 
Casing: .22 cal. rimfired \\
\end{tabular} & 2 & & & & & & & & & & \\
\hline & \begin{tabular}{|l|} 
Other Hardware \\
\end{tabular} & 2 & 1 & & & & 1 & 1 & & & & 6 \\
\hline & \begin{tabular}{|l|} 
Concrete fragments \\
\end{tabular} & 87 & & & & & & & & & & 89 \\
\hline & \begin{tabular}{|l|} 
Plaster \\
\end{tabular} & & & 2 & & & & & & & & \\
\hline & \begin{tabular}{|l|l|} 
Mortar \\
\end{tabular} & & 2 & & & & 1 & & & & & 7 \\
\hline & \begin{tabular}{|l|} 
Tile \\
\end{tabular} & 9 & & 4 & & 6 & & 7 & & & & 27 \\
\hline & Wire & 6 & & & & & & & & & & \\
\hline & Fence staple & 1 & 1 & & & & & & & & & $\mathbf{2}$ \\
\hline & Iron scrap & 17 & 94 & & 6 & & 9 & 15 & & & & 148 \\
\hline & \begin{tabular}{|l} 
Melted glass \\
\end{tabular} & 6 & $\overline{4}$ & & & & & & & & & 10 \\
\hline & Tar & & 3 & & & & & & & & & \\
\hline & Bone & 10 & 66 & 33 & 49 & 85 & 38 & 151 & 156 & 44 & & 635 \\
\hline & Egg shell & & & & & 1 & & & & & & \\
\hline & Mussel shell & & 3 & 1 & & & & & & 1 & & \\
\hline & Total Non-diagnostic & 256 & 199 & 47 & 65 & 114 & 53 & 194 & 167 & 47 & 3 & 1,145 \\
\hline \multicolumn{2}{|c|}{ Total Artifacts } & 341 & 291 & 90 & 82 & 154 & 83 & 288 & 203 & 68 & 7 & $\mathbf{1 , 6 0 7}$ \\
\hline
\end{tabular}

artifacts were a few scraps of animal bone found in the softer sediments, which ended at about $83 \mathrm{cmbd}$ (Level 8). There were increasing amounts of this stone throughout Level 9, and no artifacts were recovered. The unit was terminated at $90 \mathrm{cmbd}$.

Artifacts of particular interest include an aqua bottleneck (Figure 4-4a) from Level 2 (10-20 cmbd). This bottle fragment shows no sign of mold marks and may have been hand-blown. The neck exhibits faint tool and stretching marks. The lip was applied and finished by hand, not with a lipping tool. This bottle is most likely from the early nineteenth century, and almost certainly predates the building of the Sáenz House.

Also of interest was a fragment of Tonalá burnished ware with the remains of black and red paint (Figure 4-4b), a fragment of a doorknob made of stoneware (Figure 4-4c), and a small fragment of mold-decorated porcelain with bluegreen paint on the raised portion of the design (Figure 4-4d), all from Level 4a in the pit feature. A .32-caliber short rim-fire pistol cartridge was found in Level $4 \mathrm{~b}$, outside the pit. This casing was made for the Smith and Wesson Model $1 \frac{1}{2}$, beginning shortly after the Civil War and ending at about the turn of the century (Smith and Wesson 2002). This casing has been fired twice, indicating that it was reloaded. A sherd of edge decorated white earthenware (shown in Figure 4-4e) was recovered from Level 6 (50-60 $\mathrm{cmbd})$. This type, unscalloped with an incised pattern, was made between 1825 and 1891, with maximum popularity before the Civil War (Stelle 2001).

Lithic artifacts were surprisingly common in TU $1(n=65$; Table 4-1). Fourteen (21.5\%) came from 0-40 cmbd, and a distinct peak was evident in Levels 6 and 7 with 31 flakes (47.7\%). Most of the lithics were flakes, however, in Level 7 a small biface (Figure 4-4f) and a large, crude biface were recovered.

The artifacts recovered from TU 1 present an interesting picture. As mentioned previously, the uppermost levels had a mixture of eighteenth through twentieth-century artifacts. Below $10 \mathrm{cmbd}$, however, the only artifacts dating to the twentieth century were a few wire nails that almost certainly 


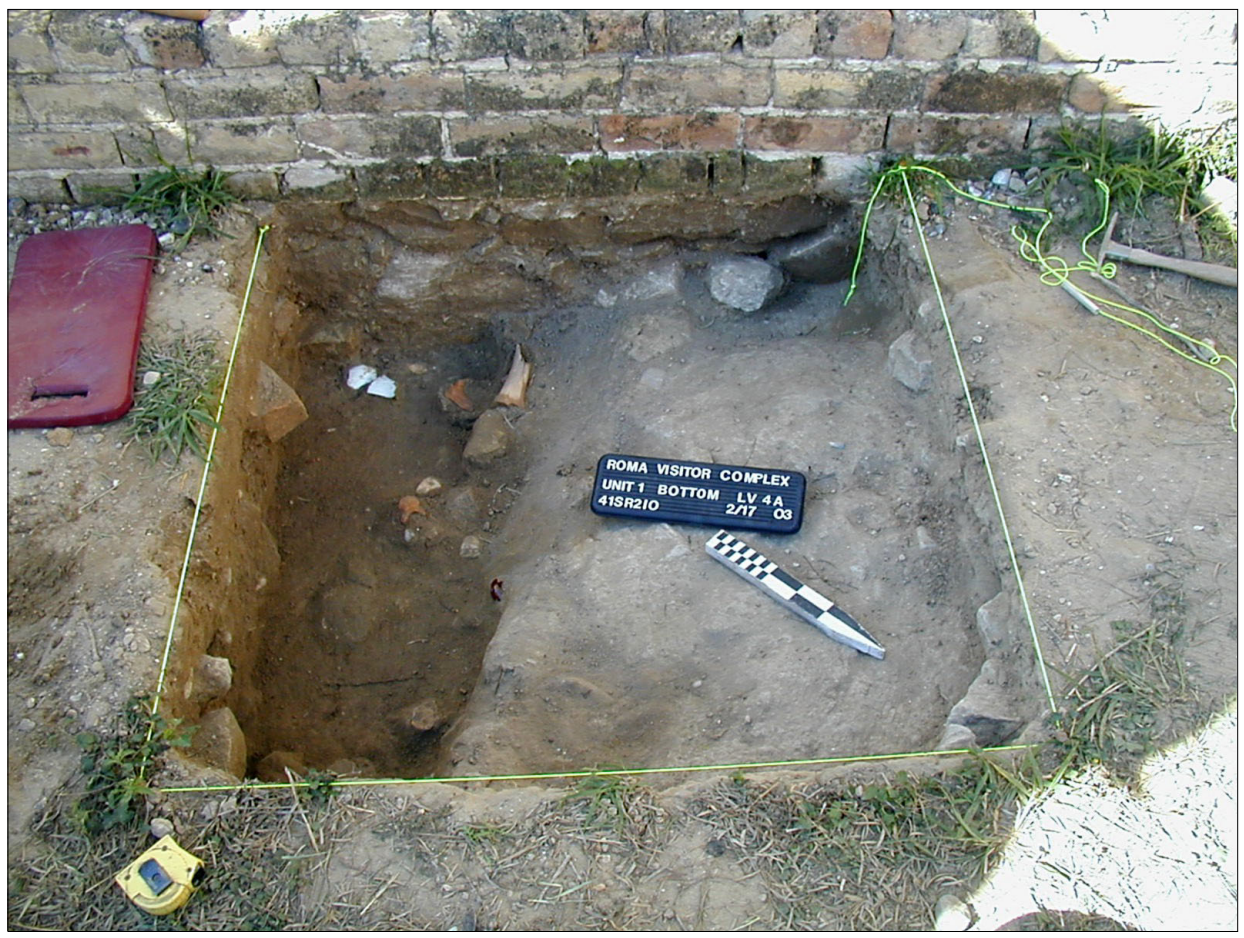

Figure 4-3. Test Unit 1 at the bottom of Level 4a, facing southwest. Note bone and ceramics in pit.

fell from the very soft, sandy sediments at the top of the unit. Excluding these, Table 4-1 makes it clear that the large majority of the diagnostic artifacts below $10 \mathrm{cmbd}$ are eighteenth and nineteenth century in origin.

Perhaps surprisingly, there is little obvious difference in dating of artifacts between the pit feature and the northern part of the unit. There is a slightly higher percentage in the Late Eighteenth to Early Nineteenth Century dating category in Levels $4 \mathrm{~b}$ and $5 \mathrm{~b}$, compared to Levels $4 \mathrm{a}$ and $5 \mathrm{a}$.

The examination of Table 4-1 reveals that presence of a peak in chipped stone artifacts in Levels 6 and 7 of the test unit. In addition, Levels $5 b$ and 6 of this unit contained large numbers of faunal remains. The identified taxa consist of cattle (Bovinae), sheep (Ovis sp.) and pig (Sus scrofa). The co-occurrence of these introduced taxa with the chipped stone artifacts suggests that the chipped stone artifacts and the deposits that contain them are Protohistoric or early Historic in age. It is equally possible, however, that the presence of bones of domesticated animals and lithics could indicate mixing of deposits and a lack of depositional integrity. Unfortunately, no independent line of evidence exists to differentiate between these alternatives, although the small number of unidentifiable glass fragments in Level 6 seems to favor the mixed deposit possibility.

Given that the deposit extends under the structure wall but does not continue away from the structure, its limits cannot be determined on the basis of the single test unit excavated by CAR. Nonetheless, the fact that the wall cross-cuts the deposits, and at least two pits appear to have been dug into each other, suggests that the materials have been severely disturbed and have poor associational integrity.

\section{The Stone Cottage (41SR2 1 1)}

Twenty-four shovel tests and two test units were dug, and one PSI test pit was monitored, at 41SR211. Figure 4-5 shows the locations of these tests.

\section{Shovel Tests}

Twenty-four shovel tests were excavated within the courtyard of the Stone Cottage. Two of these, Shovel Test 23 (ST 23) and ST 32, encountered concrete within the upper $3 \mathrm{~cm}$ and were abandoned. Four other shovel tests encountered 


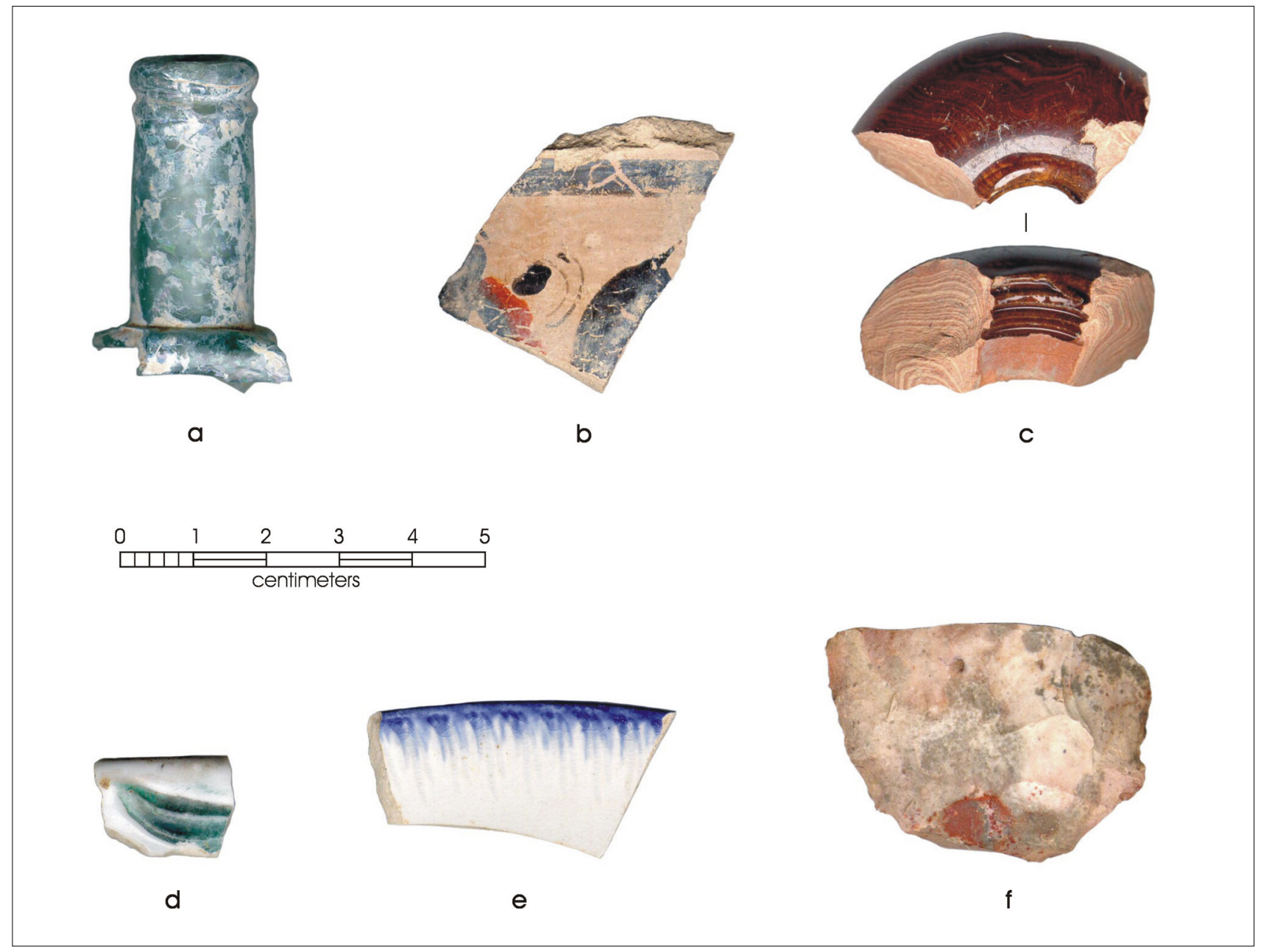

Figure 4-4. Selection of artifacts from Test Unit 1 at 41SR210. (a) hand-blown bottleneck; (b) Tonalá burnished ware; (c) stoneware doorknob; (d) mold-decorated porcelain; (e) edge decorated white earthenware; (f) biface.

obstructions below surface before their originally intended (70 cmbs) terminal depths. ST 1 encountered a PVC pipe at $30 \mathrm{cmbs}$, while STs 5, 12, and 14 encountered concrete masses at 44,58 and $59 \mathrm{cmbs}$, respectively. These shovel tests were terminated at these obstructions but the findings from these units suggest that portions of the courtyard were previously disturbed to a depth of $59 \mathrm{cmbs}$ (about two feet) at least. Examination of Appendix A, showing the materials derived from the shovel tests in the courtyard, indicates that even those units that extended to $70 \mathrm{cmbs}$ contained mixed deposits. RVC project-related construction activities within this courtyard will result in the removal of roughly 4-6 feet $(122-183 \mathrm{cmbs})$ of the deposits. The shovel tests that reached $70 \mathrm{cmbs}$ seem to suggest that the deposits decrease significantly at this depth and may not continue much below $70 \mathrm{~cm}$ below the modern surface.
Table 4-2 shows the breakdown of the artifacts recovered from all of the shovel tests by level, grouped into age classes. Appendix A shows all of the artifacts recovered by shovel test and level.

A total of 1,510 artifacts was recovered from the 24 shovel tests. The highest densities of artifacts occurred in Level 1 and decreased steadily with depth (Table 4-2). Level 7 (60$70 \mathrm{cmbs}$ ) produced only 13 artifacts. As expected, the nondiagnostic artifacts greatly outnumber temporally diagnostic items. It is interesting to note that among the temporally diagnostic artifacts, the highest percentage of Eighteenth to Early Nineteenth Century specimens occurred in Level 5, although it is surprising that the next deeper level contained the lowest percentage of early artifacts. Also revealing is the fact that the highest percentage of twentieth-century 


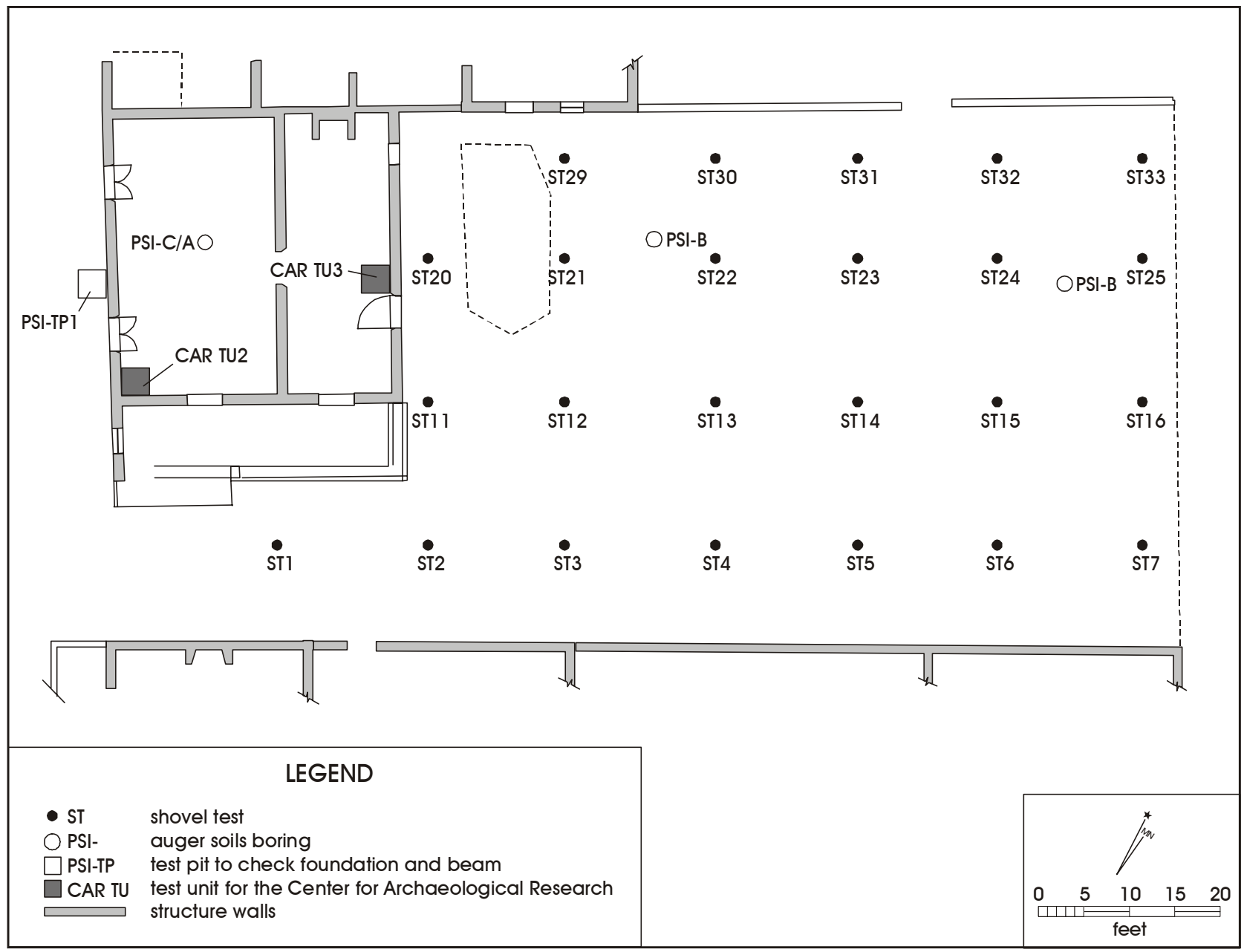

Figure 4-5. Location of shovel tests, Test Units 2 and 3, and PSI Test Pit 1 at 41SR211.

materials is found in Level 6. Nineteenth-century materials tend to cluster in Levels 3 and 4 of the shovel tests. These distribution patterns, coupled with the fact that early-nineteenth, nineteenth, and twentieth-century materials tend to be almost evenly distributed within each excavation level, seem to suggest that overall the deposits of the courtyard are mixed and retain no chronological integrity. The few chipped stone flakes $(n=9)$ recovered also occur throughout Levels 1-7, supporting the observation that the deposits are mixed.

The artifacts encountered included an array of items from modern medical and construction trash to ceramics and glass from the eighteenth century (Table 4-2). Some items of interest include a tiny fragment of Guanajuato majolica which dates from the 1830s (Fox et al. 1997) recovered from ST 6, Level 4, and two discs commonly referred to as gaming pieces were recovered from ST 7, Levels 2 and 3. One is fashioned from a fragment of milk glass (Figure 4-6a) and the other from a fragment of native earthenware (Figure 4-6b). ST 12 produced a glass marble in Level 6 (Figure 4-6c). This marble is handmade and translucent, and dates to between 1847 and about 1900 (Zapata 1997:110). One-half of a 4-hole, machine-made bone button was found in ST 13, Level 3, and probably dates to the last quarter of the nineteenth century or first quarter of the twentieth century (Figure 4-6d). One faceted, teardrop-shaped glass bead was recovered from ST 16, Level 3 (Figure 4-6e).

One fragment of German porcelain was recovered in Level 3 of ST 24. The maker's mark includes the word "Germa..." indicating a date after the unification of Germany in 1871 
Table 4-2. Artifacts Recovered from Shovel Tests, by Level and Age Class, at 41SR211

\begin{tabular}{|c|c|c|c|c|c|c|c|c|c|}
\hline $\begin{array}{c}\text { Approximate } \\
\text { Dates }\end{array}$ & Artifact Types & $\begin{array}{r}\text { ฮี } \\
-\frac{0}{0} \\
>0\end{array}$ & 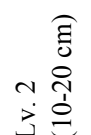 & 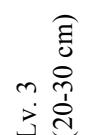 & 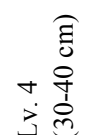 & 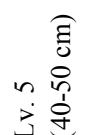 & 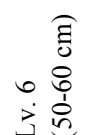 & 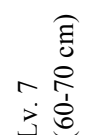 & हีํํ \\
\hline \multirow{14}{*}{$\begin{array}{l}\text { 18th to Early } \\
19 \text { th Century }\end{array}$} & Lithics & 1 & 3 & 0 & & 1 & 1 & 3 & 9 \\
\hline & Unglazed (Unrefined) ceramics & 1 & & & 1 & & & & 2 \\
\hline & Unglazed burnished ceramics & & & 1 & & & & & 1 \\
\hline & Tin glazed: Guanajuato polychrome & & & & 1 & & & & 1 \\
\hline & Lead glazed-Sandy paste ware & 1 & 1 & & 1 & 2 & 2 & & 7 \\
\hline & Lead glazed-Unidentified & & 1 & & & & & & 1 \\
\hline & Lead glazed-Galera & & 1 & & & & & & 1 \\
\hline & White earthenware (Handpainted) & 1 & & & 2 & 4 & & & 7 \\
\hline & Glass: Olive & 10 & 2 & 3 & 4 & 4 & 1 & & 24 \\
\hline & Gaming piece:glass & & 1 & & & & & & 1 \\
\hline & Gaming piece: Unglazed native ceramics & & & 1 & & & & & 1 \\
\hline & Brick, handmade & 16 & 8 & 11 & 4 & 2 & & 1 & 42 \\
\hline & Total 18th to Early 19th & 30 & 17 & 16 & 13 & 13 & 4 & 4 & 97 \\
\hline & $\%$ of Diagnostic Artifacts in Level & $29.7 \%$ & $19.3 \%$ & $28.6 \%$ & $28.9 \%$ & $36.1 \%$ & $16.0 \%$ & $57.1 \%$ & \\
\hline \multirow{11}{*}{ 19th Century } & White earthenware (Unidentified) & & & & 1 & & & 1 & 2 \\
\hline & White earthenware (Undecorated) & & 4 & 2 & 3 & 1 & & & 10 \\
\hline & \begin{tabular}{|l|} 
White earthenware (Sponge) \\
\end{tabular} & & & & 1 & 1 & & & 2 \\
\hline & White earthenware (Annular) & & & & & 1 & 1 & & 2 \\
\hline & White earthenware (Transfer) & & & & 1 & & & & 1 \\
\hline & Stoneware & 1 & & 1 & & & & & 2 \\
\hline & Lamp chimney glass & 34 & 29 & 18 & 11 & 6 & 3 & & 101 \\
\hline & Clothing: Buttons: Bone & & & 1 & & & & & 1 \\
\hline & Nails: Cut & 3 & 2 & 4 & 2 & & & & 11 \\
\hline & Total 19th Century & 38 & 35 & 26 & 19 & 9 & 4 & 1 & 132 \\
\hline & $\%$ of Diagnostic Artifacts in Level & $37.6 \%$ & $39.8 \%$ & $46.4 \%$ & $42.2 \%$ & $25.0 \%$ & $16.0 \%$ & $14.3 \%$ & \\
\hline \multirow{5}{*}{$\begin{array}{l}\text { Late 19th to } \\
\text { Early 20th } \\
\text { Century }\end{array}$} & White earthenware: Plain colored & & 1 & & & & & & 1 \\
\hline & Glass: Clear (purpled) & & & 1 & & & & 1 & 2 \\
\hline & Toy: Marble & & & & & & 1 & & 1 \\
\hline & Total Late 19th to Early 20th & $\mathbf{0}$ & 1 & 1 & $\mathbf{0}$ & $\mathbf{0}$ & 1 & 1 & 4 \\
\hline & $\%$ of Diagnostic Artifacts in Level & $0.0 \%$ & $1.1 \%$ & $1.8 \%$ & $0.0 \%$ & $0.0 \%$ & $4.0 \%$ & $14.3 \%$ & \\
\hline \multirow{9}{*}{ 20th Century } & Crown caps & 3 & 1 & & & & & & 4 \\
\hline & Pull tabs & 6 & 1 & & & 1 & & & 8 \\
\hline & \begin{tabular}{|l|} 
Nails: Wire \\
\end{tabular} & 5 & 16 & 7 & 1 & 5 & 1 & 1 & 36 \\
\hline & Kitchen: Stainless steel knife & & & 1 & & & & & 1 \\
\hline & Plastic syringe & & & 1 & 1 & & & & 2 \\
\hline & Glass drug vial & & & & 1 & & & & 1 \\
\hline & Plastic & 19 & 17 & 4 & 10 & 8 & 15 & & 73 \\
\hline & Total 20th Century & 33 & 35 & 13 & 13 & 14 & 16 & 1 & 125 \\
\hline & $\%$ of Diagnostic Artifacts in Level & $32.7 \%$ & $39.8 \%$ & $23.2 \%$ & $28.9 \%$ & $38.9 \%$ & $64.0 \%$ & $14.3 \%$ & \\
\hline \multicolumn{2}{|c|}{ Total Diagnostic Artifacts } & 101 & 88 & 56 & 45 & 36 & 25 & 7 & 358 \\
\hline
\end{tabular}


Table 4-2. continued...

\begin{tabular}{|c|c|c|c|c|c|c|c|c|c|}
\hline $\begin{array}{c}\text { Approximate } \\
\text { Dates }\end{array}$ & Artifact Types & 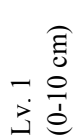 & 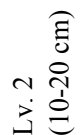 & 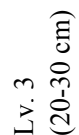 & 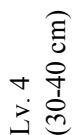 & 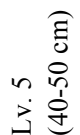 & $\begin{array}{rl} & \widehat{E} \\
& \\
0 & 8 \\
0 & 1 \\
\dot{3} & 0 \\
0\end{array}$ & 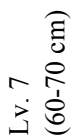 & हีّ \\
\hline \multirow{36}{*}{ Non-diagnostic } & Porcelain & 1 & 2 & 1 & 1 & & & & 5 \\
\hline & Glass:Brown & 23 & 22 & 22 & 6 & 2 & 2 & 1 & 78 \\
\hline & Glass: Aqua & 1 & 5 & 7 & 3 & & & & 16 \\
\hline & Glass: Blue & & 5 & 1 & & & & & 6 \\
\hline & Glass: Green & 13 & 4 & & & 2 & 2 & 1 & 22 \\
\hline & Glass: Clear & 221 & 192 & 105 & 78 & 29 & 19 & & 644 \\
\hline & Glass: Milk & 1 & 1 & & & & & & 2 \\
\hline & Glass: Pink & & & 1 & & & & & 1 \\
\hline & Clear glass bottle neck & 2 & & & & & & & 2 \\
\hline & Clear glass bottle & & & 1 & & & & & 1 \\
\hline & Window glass & 32 & 20 & 4 & 1 & & 1 & & 58 \\
\hline & Mirror glass & & & 1 & & & & & 1 \\
\hline & Jewelry: glass bead & & & 1 & & & & & 1 \\
\hline & Iron shoe horns & & & & 2 & & & & 2 \\
\hline & Metal eyelet & & & & & & 1 & & 1 \\
\hline & Misc. Hardware & 2 & 2 & 4 & 2 & & 1 & & 11 \\
\hline & Concrete fragments & 1 & & & & 1 & & & 2 \\
\hline & \begin{tabular}{|l|} 
Plaster \\
\end{tabular} & 13 & 6 & 2 & 2 & 1 & & & 24 \\
\hline & Mortar & 7 & 7 & 6 & & 1 & & & 21 \\
\hline & Brick--Modern & 1 & & & & & & & 1 \\
\hline & \begin{tabular}{|l|} 
Tile \\
\end{tabular} & 1 & 1 & 1 & 2 & 4 & & & 9 \\
\hline & Electrical: Light bulb & & & 1 & & & & & 1 \\
\hline & \begin{tabular}{|l} 
Wire:Electrical \\
\end{tabular} & 2 & 1 & 1 & & 1 & & & 5 \\
\hline & Wire: Other & & & 1 & 2 & & & & 3 \\
\hline & Misc. Hardware & 4 & 3 & & & & & & 7 \\
\hline & Iron scrap & 8 & 10 & 8 & 7 & 7 & 2 & 3 & 45 \\
\hline & Copper scrap & & & & & & 1 & & 1 \\
\hline & Cork & 1 & & & & & & & 1 \\
\hline & Bottle caps & & 1 & 1 & & & & & 2 \\
\hline & Tar & 1 & 4 & & & & & & 5 \\
\hline & Metal Foil & 9 & 2 & & & & & & 11 \\
\hline & Mica & & & 2 & 3 & 1 & & & 6 \\
\hline & Leather & 3 & & & & & & & 3 \\
\hline & Bone & 38 & 8 & 9 & 9 & 32 & 54 & 1 & 151 \\
\hline & Mussel shell & 1 & & 2 & & & & & 3 \\
\hline & Total Non-diagnostic & 386 & 296 & 182 & 118 & 81 & 83 & 6 & 1,152 \\
\hline \multicolumn{2}{|l|}{ Total Artifacts } & 487 & 384 & 238 & 163 & 117 & 108 & 13 & 1,510 \\
\hline
\end{tabular}




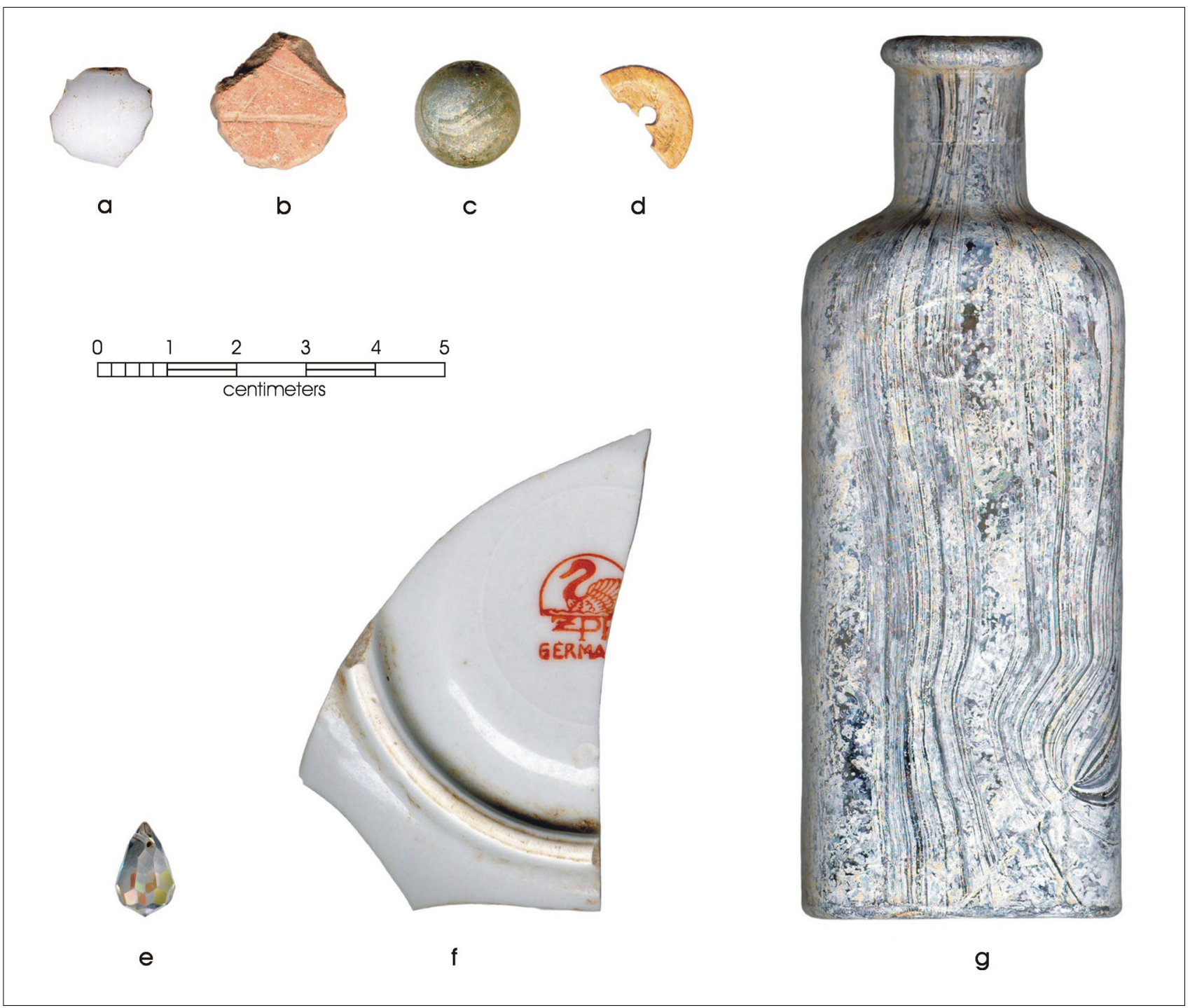

Figure 4-6. Selected artifacts from shovel tests at 41SR211. (a) milk glass gaming piece; (b) native earthenware gaming piece; (c) handmade, glass marble; (d) bone button; (e) glass bead; (f) German porcelain; (g) mold-made clear glass bottle.

(Figure 4-6f). Level 3 of ST 24 also produced a complete, clear glass bottle with a metal stopper (Figure 4-6g). The bottle, which was made in a mold and has an applied lip shaped with a lipping tool, exhibits a mark on the front panel that cannot be deciphered. It is heavily patinated in a pattern that indicates it was on the surface and subject to frequent drying in a shallow mud puddle for at least some period of time. It probably once had a paper label, and was possibly utilized as a medicine container. This bottle probably dates to the last quarter of the nineteenth century.

\section{Test Unit 2}

This unit was located in the south corner of the main room of the Stone Cottage, in the oldest part of the building (Figure 4-5). Before the unit was excavated, city workers cut and removed about $7 \mathrm{~cm}$ of concrete flooring over $4 \mathrm{~cm}$ of soft sandstone flagstones. The vertical datum was set $5 \mathrm{~cm}$ above the ground surface under the concrete. One glass marble was recovered from the surface of this unit. The marble is an opaque single-patch marble in orange and white (Figure 4-7a). It is an early machine-made marble dating between 1900 and about 1926 (Zapata 2002:111) 


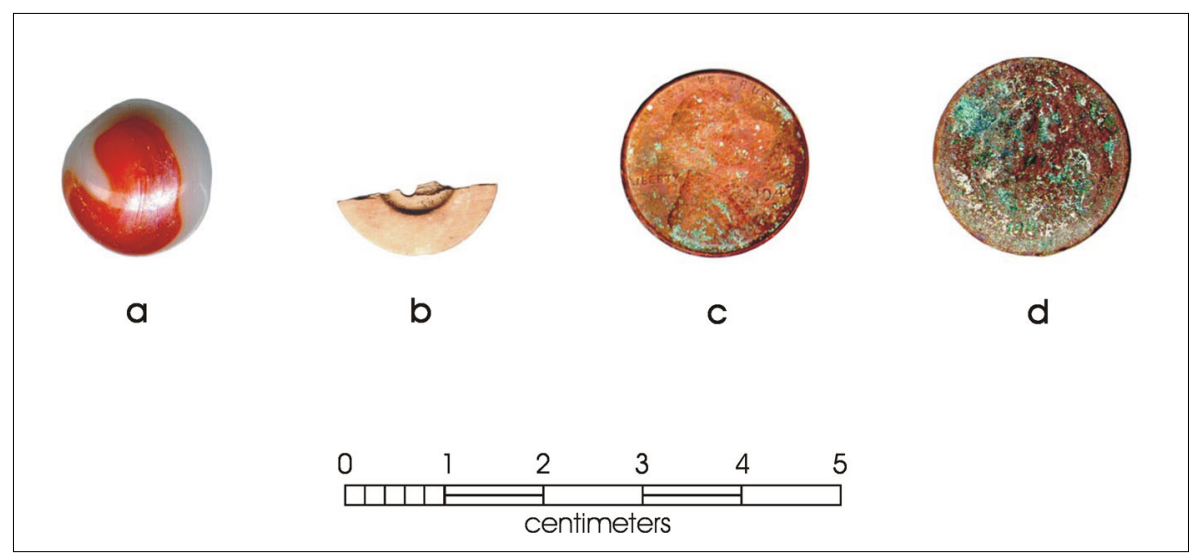

Figure 4-7. Selected artifacts from test units inside the Stone Cottage (41SR211). (a) glass marble; (b) bone button; (c) 1947 U.S. penny; (e) 1937 Mexican centavo.

Below the concrete and flagstone floor, the sediments were light yellowish-brown (10YR6/4) sandy clay loam, with very few gravel inclusions, that continued to about $20 \mathrm{cmbd}$, with increasing numbers of large $(7-10 \mathrm{~cm})$ sandstone rocks and yellow handmade bricks in the lower part of this layer. The sediments then changed to a lighter colored $(2.5 \mathrm{Y} 6 / 4)$ and sandier loam with about $40-50 \%$ pea-sized gravels and no large sandstone rocks. The percent of gravels decreased markedly as the excavation continued to about $53 \mathrm{cmbd}$; however, beginning at about $40 \mathrm{cmbd}$ numerous medium to large $(5-10 \mathrm{~cm})$ sandstone rocks comprised about $10 \%$ of the total matrix. A very large $(\mathrm{ca} .40 \mathrm{~cm})$ rock was located in the southeast wall in Level $5(40-50 \mathrm{cmbd})$.

Although the sediment did not change color from the previous level, at about $53 \mathrm{cmbd}$ there was a sudden increase in gravel and sandstone fragments (from pea-sized to ca. 8 $\mathrm{cm}$ ), and sediments become harder. Sediments continued to become more hard-packed to $64 \mathrm{cmbd}$, when an almost solid layer of sandstone was encountered. Level $7(60-64 \mathrm{cmbd})$ was terminated at this depth.

Most of Level 8 (64-74 cmbd) was soft sandstone, with occasional large pieces of harder limestone (up to $25 \mathrm{~cm}$ in size). The sediment around these rocks was a brownishyellow $(2.5 \mathrm{Y} 6 / 6)$ sandy loam. The layer of large stones ended just above $74 \mathrm{cmbd}$. The sediments continued the same color and texture with 1-5\% pea-sized gravels to the bottom of the unit at $94 \mathrm{cmbd}$. A wall footer was revealed on the south and west walls at approximately $92 \mathrm{cmbd}$ (Figure 4-8).
Artifacts from this unit were sparse $(\mathrm{n}=169)$. Except for Level 1, all diagnostic artifacts were nineteenth-century or earlier (Table 4-3). For instance, a bone button (Figure 4-7b) found in Level 8, is handmade, and probably dates from the middle of the nineteenth century. Artifact counts were noticeably higher in Levels 5 through $8(40-74 \mathrm{cmbd})$ and then dropped off sharply in Level 9. No artifacts were recovered from Level 10 (84-94 cmbd). The five chipped stone flakes from the unit came from Levels 2, 3, and 5. Their distribution may represent as extension of the lithics from 41SR210.

\section{Test Unit 3}

Test Unit 3 was located in the Stone Cottage extension, against the back wall (Figure 4-5). Prior to excavation, the bricks covering this part of the floor were removed (Figure 4-9). The vertical datum was located $10 \mathrm{~cm}$ above ground level.

The upper $7 \mathrm{~cm}$ of sediment was a pale brown (10YR6/3) soft sandy loam. Very few inclusions were recorded in the first $5 \mathrm{~cm}$ of excavation. Below that, evidence of cultural material began to appear. Excavation of this level was terminated at $17 \mathrm{cmbd}$ due to a color change in the soil. The sediments appeared darker and were much harder. At about $37 \mathrm{cmbd}$, the soils changed to a light yellowish-brown (2.5Y6/4) dense clay loam with small gravel inclusions.

At the time of excavation, what appeared to be a hard-packed caliche floor was revealed in patches beginning at about 43 cmbd. Further excavation revealed that it was a natural 


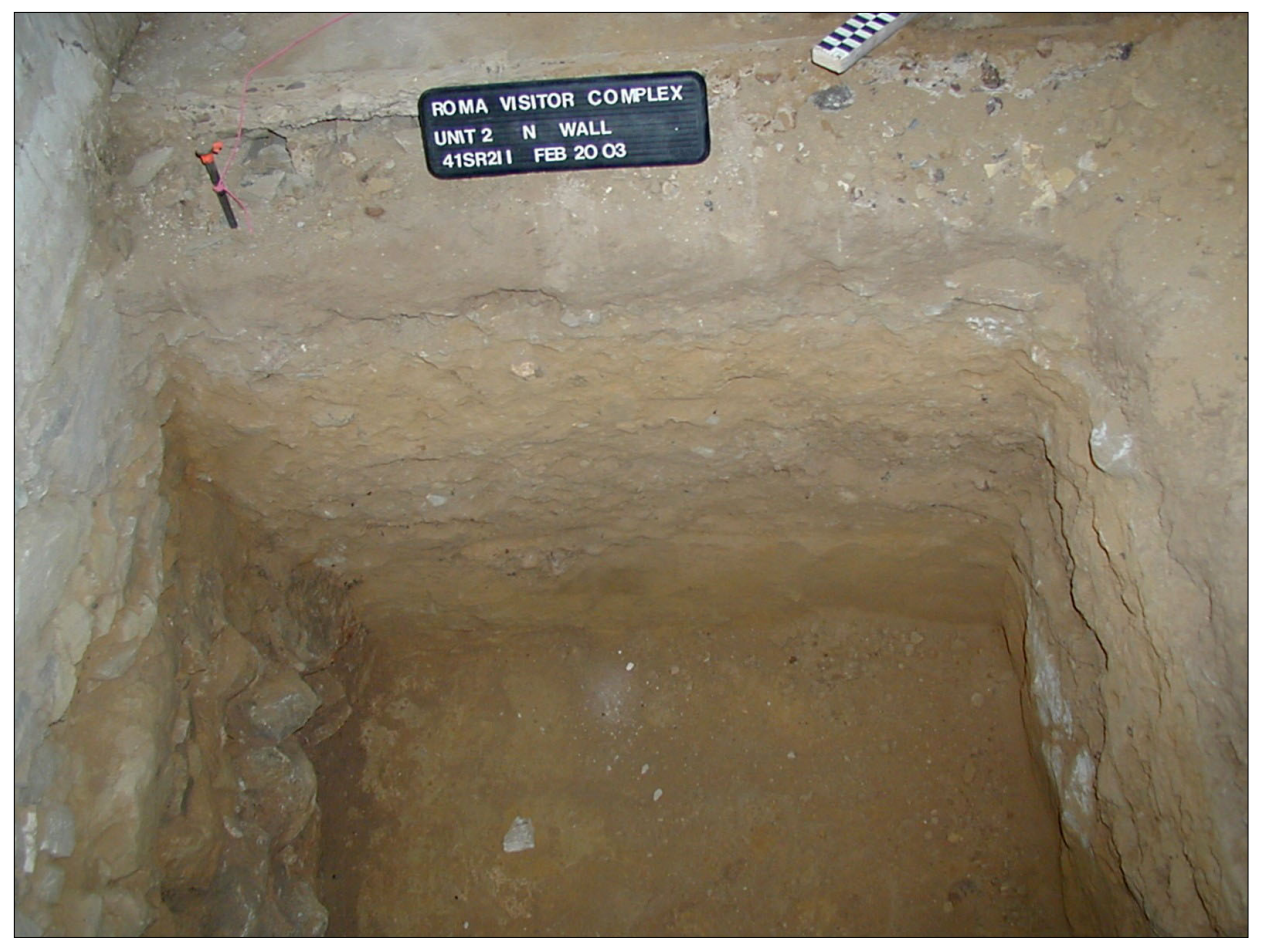

Figure 4-8. Bottom of Test Unit 2 showing wall footer in west wall.

occurrence, layers of compact sandy silt separated by a white crust. It is possible that the layers were the result of flooding incidents. No artifacts were recovered below $37 \mathrm{cmbd}$. The unit was terminated at $57 \mathrm{cmbd}$.

Artifacts in this unit were extremely sparse, totaling only 173 pieces, $85 \%$ of which were in Level 1 (Table 4-4). Two coins located in Level 1 were a 1947 U.S. penny (Figure 4-7c), struck in Denver, and a 1937 Mexican centavo (Figure 4-7d). Plaster, mortar, and concrete fragments comprised $30.6 \%$ of the total artifacts. A single chipped stone core was recovered from Level 3 of the unit.

\section{Monitoring}

One test pit was excavated by PSI within the Stone Cottage site. PSI Test Pit 1 was located outside the building between the two entrances along Portscheller Street (Figure 4-5). The base of the wall was located quickly and additional digging in the unit was not necessary. No significant cultural material was observed.

\section{Discussion}

The excavation of the test units within the Stone Cottage structure indicate that the interior had been swept clean of most material, possibly even excavated to some degree, filled, and then paved with either concrete or brick. Both rooms exhibited similar soil types, as well as a lack of cultural material. The majority of the material collected is composed of building material (i.e., brick, mortar, plaster, concrete) and faunal remains.

Shovel test excavations did produce some interesting items, but many of the tests were riddled with modern construction and medical refuse. The north-central portion of the courtyard could not be tested due to the presence of a layer of concrete. There is a possibility that undisturbed deposits are present under the concrete layer. The few chipped stone artifacts from the site may represent an extension of the prehistoric/Protohistoric component identified at 41SR210. 
Table 4-3. Artifacts Recovered from Test Unit 2, 41SR211

\begin{tabular}{|c|c|c|c|c|c|c|c|c|c|c|c|c|}
\hline $\begin{array}{c}\text { Approximate } \\
\text { Dates }\end{array}$ & Artifact Types & 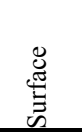 & $\begin{array}{rl} & \widehat{\Xi} \\
- & 0 \\
\dot{y} & 0 \\
\end{array}$ & 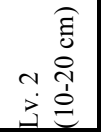 & 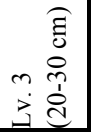 & 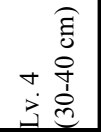 & 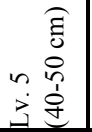 & 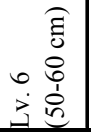 & 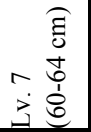 & 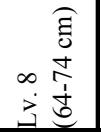 & 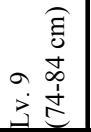 & 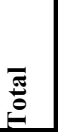 \\
\hline \multirow{6}{*}{$\begin{array}{l}\text { 18th to Early } \\
19 \text { th Century }\end{array}$} & Lithics & & & 1 & 1 & & 3 & & & & 0 & 5 \\
\hline & White earthenware (Handpainted) & & & & & 1 & 1 & 5 & 1 & & & 8 \\
\hline & Glass: Olive & & & & & 1 & 2 & 6 & 4 & & & 13 \\
\hline & Brick, handmade & & 1 & 5 & & & 1 & 2 & & & & 9 \\
\hline & Total 18th to Early 19th & $\mathbf{0}$ & 1 & 6 & 1 & 2 & 7 & 13 & 5 & $\mathbf{0}$ & $\mathbf{0}$ & 35 \\
\hline & $\%$ of Diagnostic Artifacts in Level & $0.0 \%$ & $100.0 \%$ & $100.0 \%$ & $25.0 \%$ & $100.0 \%$ & $77.8 \%$ & $72.2 \%$ & $50.0 \%$ & $0.0 \%$ & $0.0 \%$ & \\
\hline \multirow{8}{*}{ 19th Century } & White earthenware (Undecorated) & & & & 2 & & & & & & & 2 \\
\hline & White earthenware (Annular) & & & & & & & 2 & 1 & & & 3 \\
\hline & Yellow ware & & & & & & 1 & & & & & 1 \\
\hline & Glass: Dark olive ("black") & & & & 1 & & & 1 & 4 & & & 6 \\
\hline & Clothing: Buttons: Bone & & & & & & & & & 1 & & 1 \\
\hline & Nails: Cut & & & & & & 1 & 2 & & & & 3 \\
\hline & Total 19th Century & $\mathbf{0}$ & $\mathbf{0}$ & $\mathbf{0}$ & 3 & $\mathbf{0}$ & 2 & 5 & 5 & 1 & $\mathbf{0}$ & 16 \\
\hline & $\%$ of Diagnostic Artifacts in Level & $0.0 \%$ & $0.0 \%$ & $0.0 \%$ & $75.0 \%$ & $0.0 \%$ & $22.2 \%$ & $27.8 \%$ & $50.0 \%$ & $100.0 \%$ & $0.0 \%$ & \\
\hline \multirow{3}{*}{$\begin{array}{l}\text { Late } 19 \text { th to } \\
\text { Early 20th } \\
\text { Century }\end{array}$} & Toys: Glass marble & 1 & & & & & & & & & & 1 \\
\hline & Total Late 19th to Early 20th & 1 & $\mathbf{0}$ & $\mathbf{0}$ & 0 & $\mathbf{0}$ & $\mathbf{0}$ & $\mathbf{0}$ & 0 & 0 & $\mathbf{0}$ & 1 \\
\hline & $\%$ of Diagnostic Artifacts in Level & $50.0 \%$ & $0.0 \%$ & $0.0 \%$ & $0.0 \%$ & $0.0 \%$ & $0.0 \%$ & $0.0 \%$ & $0.0 \%$ & $0.0 \%$ & $0.0 \%$ & \\
\hline \multirow{3}{*}{ 20th Century } & Nails: Wire & 1 & & & & & & & & & & 1 \\
\hline & Total 20th Century & 1 & $\mathbf{0}$ & $\mathbf{0}$ & $\mathbf{0}$ & $\mathbf{0}$ & 0 & 0 & 0 & $\mathbf{0}$ & 0 & 1 \\
\hline & $\%$ of Diagnostic Artifacts in Level & $50.0 \%$ & $0.0 \%$ & $0.0 \%$ & $0.0 \%$ & $0.0 \%$ & $0.0 \%$ & $0.0 \%$ & $0.0 \%$ & $0.0 \%$ & $0.0 \%$ & \\
\hline \multicolumn{2}{|c|}{ Total Diagnostic Artifacts } & 2 & 1 & 6 & 4 & 2 & 9 & 18 & 10 & 1 & $\mathbf{0}$ & 53 \\
\hline \multirow{13}{*}{ Non-diagnostic } & Glass: Brown & & 2 & & & & & & & & & 2 \\
\hline & Glass: Aqua & & 2 & & & & & 8 & 2 & 1 & & 12 \\
\hline & Glass: Cobalt & & & & & & 1 & & & & & 1 \\
\hline & Glass: Clear & & 1 & & & & & 2 & & & & 3 \\
\hline & Window glass & 1 & & & & & & & & & & 1 \\
\hline & Plaster & & & 3 & & & & & & & & 3 \\
\hline & Tile & & 2 & 4 & 2 & & & & & & & 8 \\
\hline & Iron scrap & & & & & & & & 3 & & & 3 \\
\hline & Copper scrap & & & & & & & & 1 & 1 & & 2 \\
\hline & Paper & & & 1 & & & & & & & & 1 \\
\hline & Wood & & 2 & & & & & & & & & 2 \\
\hline & Bone & & & & & & 5 & 13 & 9 & 46 & 4 & 77 \\
\hline & Total Non-diagnostic & 1 & 9 & 8 & 2 & $\mathbf{0}$ & 6 & 23 & 15 & 48 & 4 & 115 \\
\hline \multicolumn{2}{|c|}{ Total Artifacts } & 3 & 10 & 14 & 6 & 2 & 15 & 41 & 25 & 49 & 4 & 169 \\
\hline
\end{tabular}




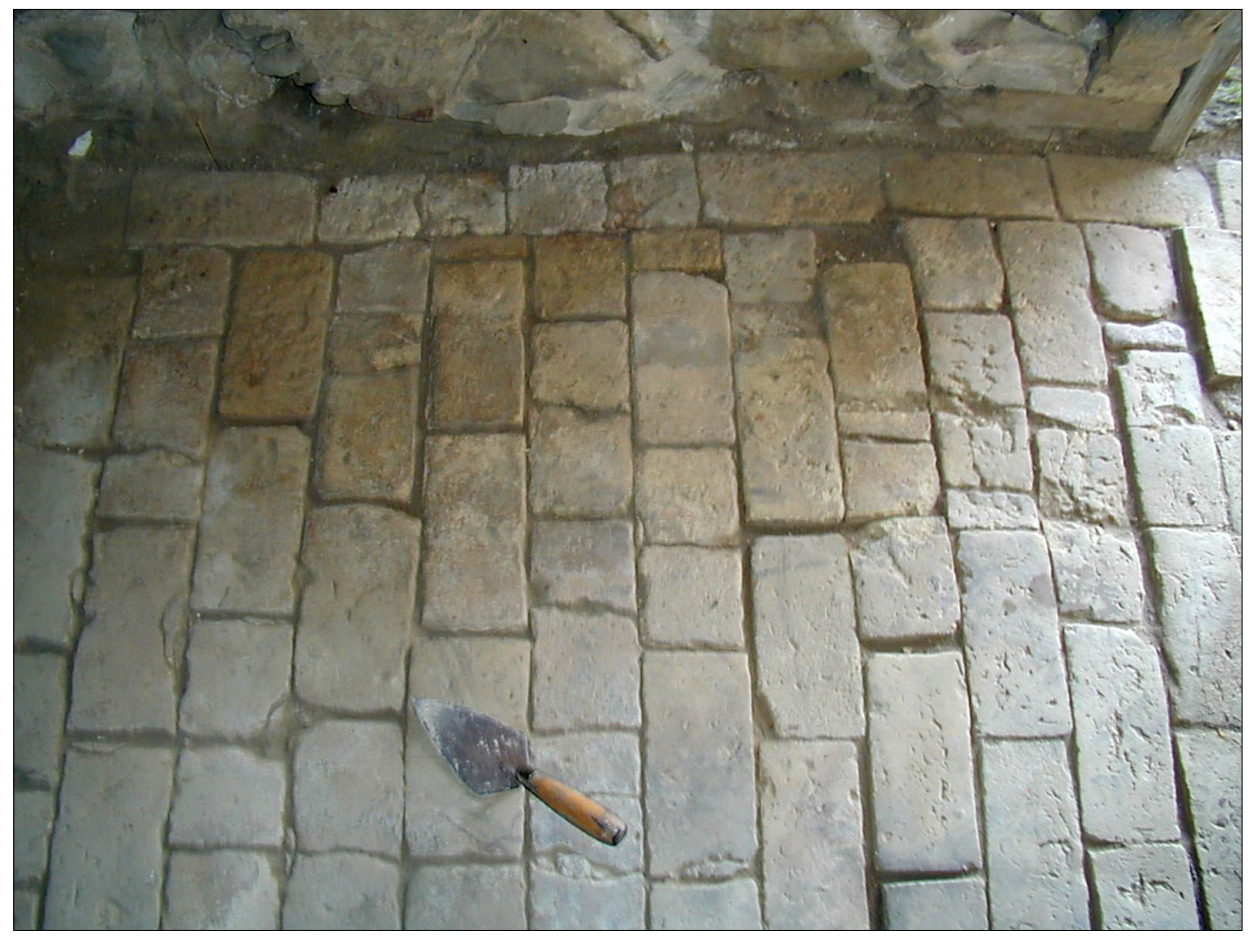

Figure 4-9. Brick floor prior to the excavation of Test Unit 3 in the Stone Cottage, 41SR311.

Table 4-4. Artifacts Recovered from Test Unit 3, 41SR211

\begin{tabular}{|c|c|c|c|c|c|c|}
\hline $\begin{array}{l}\text { Approximate } \\
\text { Dates }\end{array}$ & Artifact Types & 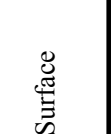 & 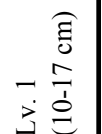 & 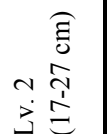 & 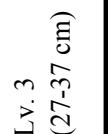 & हूँ \\
\hline \multirow{4}{*}{$\begin{array}{l}\text { 18th to Early } \\
\text { 19th Century }\end{array}$} & Lithics & & & & & \\
\hline & Brick, handmade & 2 & 37 & 3 & 6 & 46 \\
\hline & \begin{tabular}{|l|} 
Total 18th to Early 19th \\
\end{tabular} & 2 & 37 & 3 & 7 & 47 \\
\hline & $\%$ of Diagnostic Artifacts in Level & $100.0 \%$ & $94.9 \%$ & $100.0 \%$ & $100.0 \%$ & \\
\hline \multirow{4}{*}{ 20th Century } & Coin: 19371 centavo & & 1 & & & \\
\hline & Coin: 1947-D US penny & & 1 & & & \\
\hline & \begin{tabular}{|l|} 
Total 20th Century \\
\end{tabular} & 0 & 2 & 0 & 0 & \\
\hline & $\%$ of Diagnostic Artifacts in Level & $0.0 \%$ & $5.1 \%$ & $0.0 \%$ & $0.0 \%$ & \\
\hline Total Diagnostic & Artifacts & 2 & 39 & 3 & 7 & 49 \\
\hline \multirow{10}{*}{ Non-diagnostic } & Glass: Brown & & 2 & & & 2 \\
\hline & Glass: Clear & & 9 & & & 9 \\
\hline & Plaster & & & 11 & & 11 \\
\hline & Mortar & & 30 & & & 30 \\
\hline & Tile & & 15 & & & 15 \\
\hline & Iron scrap & & & & 1 & \\
\hline & Cement fragments & & 12 & & & 12 \\
\hline & Bone & & 40 & & 2 & 42 \\
\hline & Mussel Shell & & & 1 & & 1 \\
\hline & Total Non-diagnostic & 0 & 108 & 13 & 3 & 124 \\
\hline Total Artifacts & & 2 & 147 & 16 & 10 & 173 \\
\hline
\end{tabular}




\section{The Rafael García-Ramirez House and Store (41SR212)}

The only work done at this site by CAR archeologists was the monitoring of two test pits dug by PSI (Figure 4-10). PSI Test Pit 8 was located inside the Ramirez building, within the northernmost room. The pit was placed where the interior west and north walls meet. Soil encountered resembled the soil from Test Unit 1 at the Stone Cottage (yellow, sterile fill). One fragment of aqua glass was observed, but not collected. The wall appeared to be approximately $33 \mathrm{~cm}$ thick.

PSI Test Pit 9 was located inside the Ramirez Store in the southern corner of the building. This wall is shared with the Stone Cottage. The wall itself is composed of mortared stone, unlike the other walls which are made of brick. The construction of this wall indicates that the Stone Cottage (41SR211) was constructed before the Ramirez Store. A portion of the wooden floor was removed in order to excavate the pit. Cultural material recovered from this pit included two fragments of hand-painted white earthenware (early nineteenth century), one square finishing nail, and one lithic fragment. There was no evidence of a concentration of material that could be classified as a trash pit, therefore PSI proceeded to excavate to the depth needed.

\section{The Ramirez Hospital (41 SR2 15)}

The scope of work called for two 1-x-1-m test units to be excavated inside the oldest part of the Ramirez Hospital (Figure 4-11). These were designated Test Unit 5 and Test Unit 6 . The floor inside the room was made of tongue-andgroove boards on wood joists, which in turn were resting on brick footers. Prior to excavation, portions of the floorboards were cut and removed to allow for the layout of the two 1-x-1-m units.

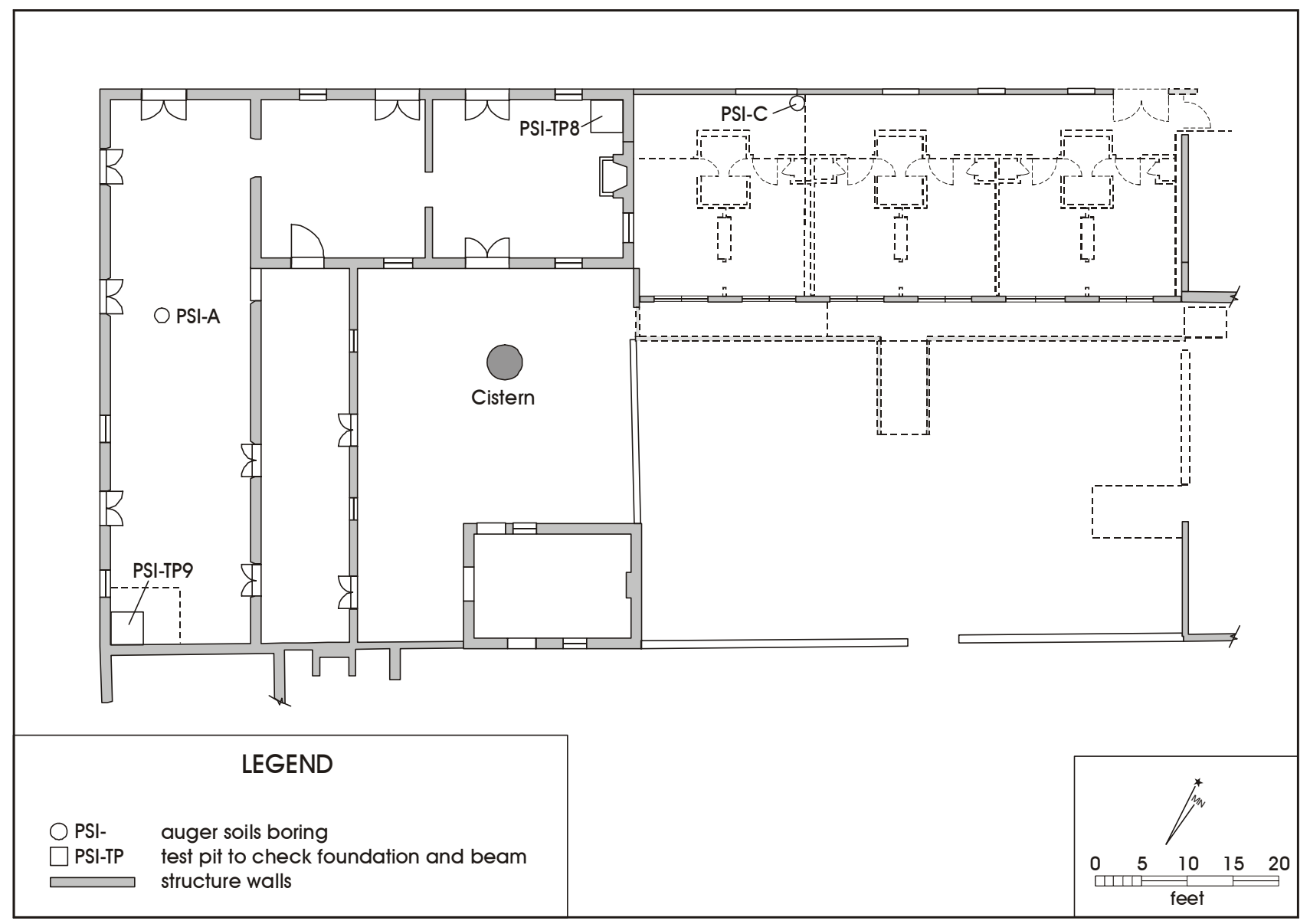

Figure 4-10. Plan map of the Ramirez House and Store (41SR212), showing locations of PSI test pits. 


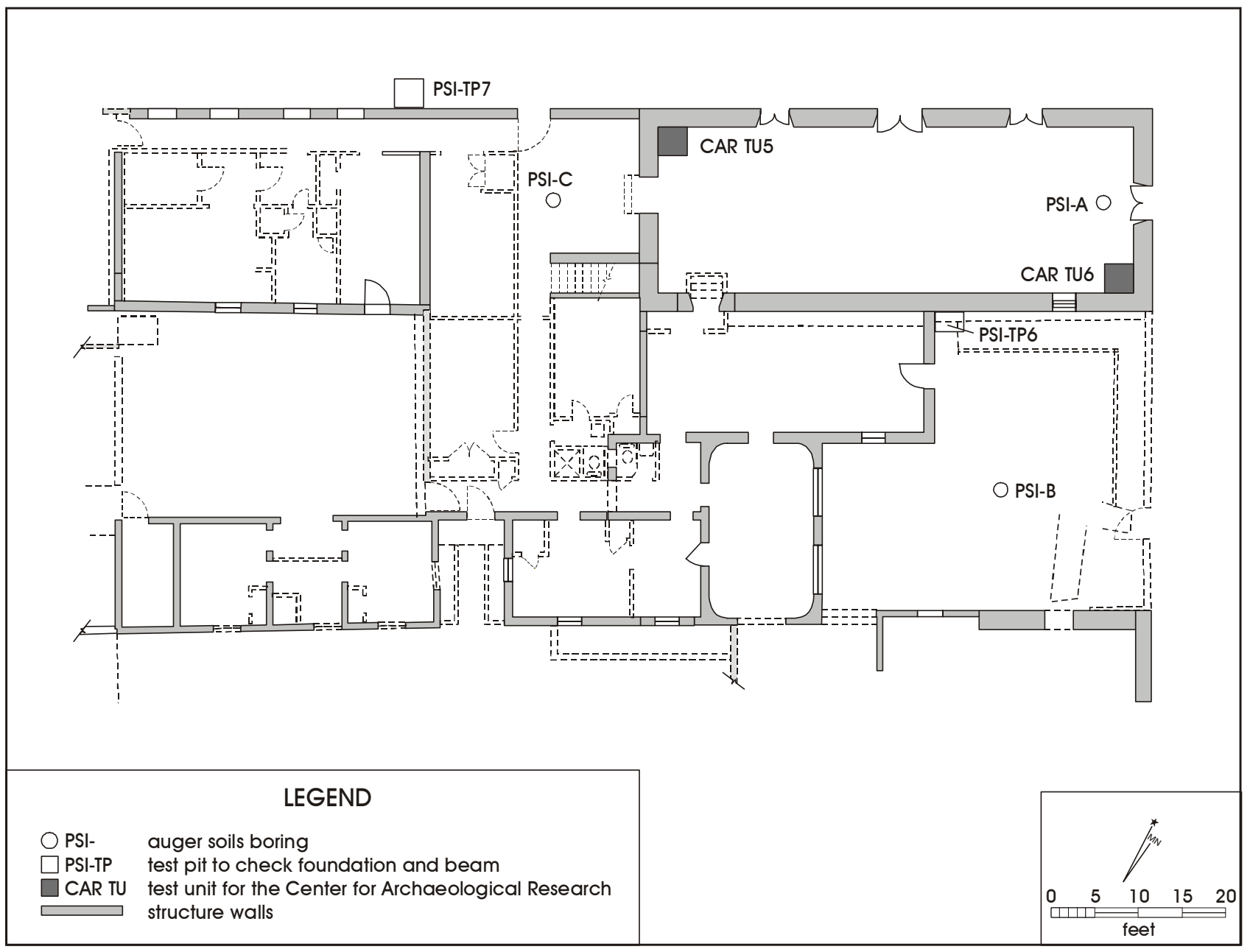

Figure 4-11. Plan map of the Ramirez Hospital (41SR215), showing locations of Test Units 5 and 6 and PSI test pits.

\section{Test Unit 5}

Test Unit 5 was located in the northwest corner of the room immediately adjacent the walls (Figure 4-11). The vertical datum was the top of the wood floor. Level 1 was limited to the upper 1-3 cm of sediments below the floor. The remaining levels were each 10-cm-thick. In Level 2, the crew worked around two floor joists, exposing and then removing the brick footers under the joists. At $31 \mathrm{cmbd}$, a concrete foundation abutment was encountered, extending out from the wall about $18 \mathrm{~cm}$. Sediment in Level 4 consisted of sandy loam with $15-20 \%$ pea-sized gravels. A single piece of brown glass and a piece of metal scrap were recovered from this level. Levels 5 (50-56 cmbd), 6 (56-66 cmbd), and 7 (66-76 cmbd) contained no artifacts.
A total of 209 artifacts was recovered from this unit (Table 4-5). The Level 1 temporally diagnostic artifacts were dominated by twentieth-century materials, while among the Level 2 materials, nineteenth-century artifacts were the most common. While Level 3 materials were also dominated by nineteenth-century materials, the proportion of eighteenth and early-nineteenth-century artifacts jumped to $43 \%$. Overall, the bulk of the artifacts were concentrated in Level 2 and date to the nineteenth century. This is consistent with the documented construction age of the structure and occupation of the residence. 
Table 4-5. Artifacts Recovered from Test Unit 5, 41SR215

\begin{tabular}{|c|c|c|c|c|c|c|}
\hline $\begin{array}{c}\text { Approximate } \\
\text { Dates }\end{array}$ & Artifact Types & 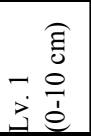 & 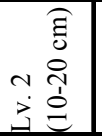 & 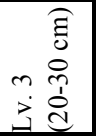 & 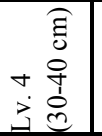 & हैं \\
\hline \multirow{6}{*}{$\begin{array}{l}\text { 18th to Early } \\
19 \text { th Century }\end{array}$} & Lead glazed-Sandy paste ware & & 1 & & & 1 \\
\hline & Lead glazed-Unidentified & 1 & & & & 1 \\
\hline & Glass: Olive & & 4 & 2 & & 6 \\
\hline & Brick, handmade & & 5 & 1 & & 6 \\
\hline & Total 18th to Early 19th & 1 & 10 & 3 & $\mathbf{0}$ & 14 \\
\hline & $\%$ of Diagnostic Artifacts in Level & $25.0 \%$ & $21.7 \%$ & $42.9 \%$ & -- & \\
\hline \multirow{7}{*}{ 19th Century } & Stoneware & & 1 & 1 & & 2 \\
\hline & Glass: Dark olive ("black") & & 22 & 3 & & 25 \\
\hline & Lamp chimney glass & & 7 & & & 7 \\
\hline & Nails: Cut & 1 & 1 & & & 2 \\
\hline & Dip pen nib & & 1 & & & 1 \\
\hline & Total 19th Century & 1 & 32 & 4 & 0 & 37 \\
\hline & $\%$ of Diagnostic Artifacts in Level & $25.0 \%$ & $69.6 \%$ & $57.1 \%$ & -- & \\
\hline \multirow{3}{*}{$\begin{array}{l}\text { Late 19th to } \\
\text { Early 20th } \\
\text { Century }\end{array}$} & Clothing: Buttons: Metal & & 1 & & & 1 \\
\hline & \begin{tabular}{|l} 
Total Late 19th to Ealy 20th \\
\end{tabular} & $\mathbf{0}$ & 1 & 0 & 0 & 1 \\
\hline & $\%$ of Diagnostic Artifacts in Level & $0.0 \%$ & $2.2 \%$ & $0.0 \%$ & -- & \\
\hline \multirow{3}{*}{ 20th Century } & Nails: Wire & 2 & 3 & & & 5 \\
\hline & \begin{tabular}{|l|} 
Total 20th Century \\
\end{tabular} & 2 & 3 & $\mathbf{0}$ & 0 & 5 \\
\hline & $\%$ of Diagnostic Artifacts in Level & $50.0 \%$ & $6.5 \%$ & $0.0 \%$ & -- & \\
\hline \multicolumn{2}{|c|}{ Total Diagnostic Artifacts } & 4 & 46 & 7 & $\mathbf{0}$ & 57 \\
\hline \multirow{16}{*}{ Non-diagnostic } & Glass: Brown & 1 & 6 & 1 & 1 & 9 \\
\hline & Glass: Aqua & & 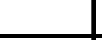 & 1 & & 1 \\
\hline & Glass: Clear & 3 & 4 & & & 7 \\
\hline & Glass: Molded Yellow & & 2 & & & 2 \\
\hline & Window glass & & 4 & & & 4 \\
\hline & Casing: .22 cal. rimfired & & 1 & 1 & & 2 \\
\hline & Plaster & 14 & 19 & 4 & & 37 \\
\hline & Tile & 2 & 2 & & & 4 \\
\hline & Metal foil & & 12 & & & 12 \\
\hline & Iron scrap & 7 & 42 & 3 & 1 & 53 \\
\hline & Copper scrap & & 3 & & & 3 \\
\hline & Wood fragments & & 8 & & & 8 \\
\hline & Paper fragments & & 1 & & & 1 \\
\hline & Bone & & 5 & 3 & & 8 \\
\hline & Mussel shell & & 1 & & & 1 \\
\hline & Total Non-diagnostic & 27 & 110 & 13 & 2 & 152 \\
\hline \multicolumn{2}{|l|}{ Total Artifacts } & 31 & 156 & 20 & 2 & 209 \\
\hline
\end{tabular}

\section{Test Unit 6}

Test Unit 6 was located in the southeast corner of the room (Figure 4-11). The vertical datum was set at the level of the top of the floor. The top of Level 1 ranged from 12 to 19 cmbd. Large amounts of plaster that had fallen from the wall were found throughout the level. The plaster fragments were absent in Level 2 (20-30 cmbd). Concrete foundation abutments (see the following discussion) were encountered in Level $3(30-40 \mathrm{cmbd})$ along the northeast and southeast walls of the unit, extending $15-18 \mathrm{~cm}$ into the unit. Sediments in Level 4 (40-50 cmbd) contained a few peasized gravels similar to those identified in Test Unit 5 above the sterile levels. No artifacts were recovered from this level. Level 5 (50-60 cmbd) also produced no artifacts. 
A total of 133 artifacts was recovered from this unit (Table 4-6). As in Test Unit 5, the Level 1 temporally diagnostic artifacts were dominated by twentieth-century materials. On the other hand, eighteenth-century to early-nineteenthcentury materials were more common among the Level 2 materials. This pattern may simply be a product of the small sample size of diagnostic artifacts from the level $(n=6)$. Overall, the bulk of the artifacts were concentrated in Level 1 and artifact densities dropped with increasing depth.

\section{Monitoring}

Two test pits were opened by PSI in the Ramirez Hospital site (Figure 4-11). PSI Test Pit 6 was located near the front entrance of the hospital along Estrella Street. This test pit was moved slightly away from the south wall of the hospital due to the presence of a concrete pipe cover. A concrete footer was located and then removed by PSI. Cultural material observed included clear glass and corroded metal. No material was collected.
PSI Test Pit 7 was located along the north wall of the hospital adjacent the plaza. The concrete walkway was removed to allow for the excavation of the test pit. A few fragments of olive colored glass and corroded metal were observed in the backfill. No artifacts were collected. This wall appears to have an approximately $61-\mathrm{cm}$-deep sandstone footing (Figure 4-12).

\section{Discussion}

While most of the artifacts recovered were construction materials and miscellaneous pieces of unidentifiable metal, Test Unit 5 did have nineteenth-century glass that may well be early nineteenth century in origin. Level 2 had 22 pieces of dark olive glass that appears black unless held to a light. This glass was placed in the general Nineteenth Century dating category because this type of glass was in use from about 1815 to about 1880 (Munsey 1970:37; Stelle 2001). In this case, however, the characteristics of the fragments of the base, neck, and body sherds strongly suggest that the

Table 4-6. Artifacts Recovered from Test Unit 6, 41SR215

\begin{tabular}{|c|c|c|c|c|c|}
\hline $\begin{array}{c}\text { Approximate } \\
\text { Dates }\end{array}$ & Artifact Type & 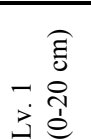 & 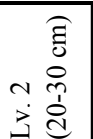 & 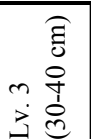 & हี่ \\
\hline \multirow{4}{*}{$\begin{array}{l}\text { 18th to Early } 19 \text { th } \\
\text { Century }\end{array}$} & Glass: Olive & 4 & 1 & 1 & 6 \\
\hline & Brick, handmade & & 3 & & 3 \\
\hline & \begin{tabular}{|l|} 
Total 18th to Early 19th \\
\end{tabular} & 4 & 4 & 1 & 9 \\
\hline & $\%$ of Diagnostic Artifacts in Level & $22.2 \%$ & $66.7 \%$ & $50.0 \%$ & \\
\hline \multirow{4}{*}{ 19th Century } & Lamp chimney glass & & 2 & & 2 \\
\hline & Nails: Cut & 1 & & & 1 \\
\hline & \begin{tabular}{|l|} 
Total \\
\end{tabular} & 1 & 2 & $\mathbf{0}$ & 3 \\
\hline & $\%$ of Diagnostic Artifacts in Level & $5.6 \%$ & $33.3 \%$ & $0.0 \%$ & \\
\hline \multirow{3}{*}{ 20th Century } & Nails: Wire & 13 & & 1 & 14 \\
\hline & Total 20th Century & 13 & 0 & 1 & 14 \\
\hline & $\%$ of Diagnostic Artifacts in Level & $72.2 \%$ & $0.0 \%$ & $50.0 \%$ & \\
\hline \multicolumn{2}{|c|}{ Total Diagnostic Artifacts } & 18 & 6 & 2 & 26 \\
\hline \multirow{10}{*}{ Non-diagnostic } & Glass: Brown & 29 & 34 & 7 & 70 \\
\hline & Window glass & 3 & & & 3 \\
\hline & Copper brad & 1 & & & 1 \\
\hline & Plaster & 3 & 9 & 6 & 18 \\
\hline & Tar paper & & 1 & & 1 \\
\hline & Tile & 2 & & & 2 \\
\hline & Iron scrap & 6 & 4 & & 10 \\
\hline & Plastic & & 1 & & 1 \\
\hline & Wood fragments & 1 & & & 1 \\
\hline & Total Non-diagnostic & 45 & 49 & 13 & 107 \\
\hline \multicolumn{2}{|l|}{ Total Artifacts } & 63 & 55 & 15 & 133 \\
\hline
\end{tabular}




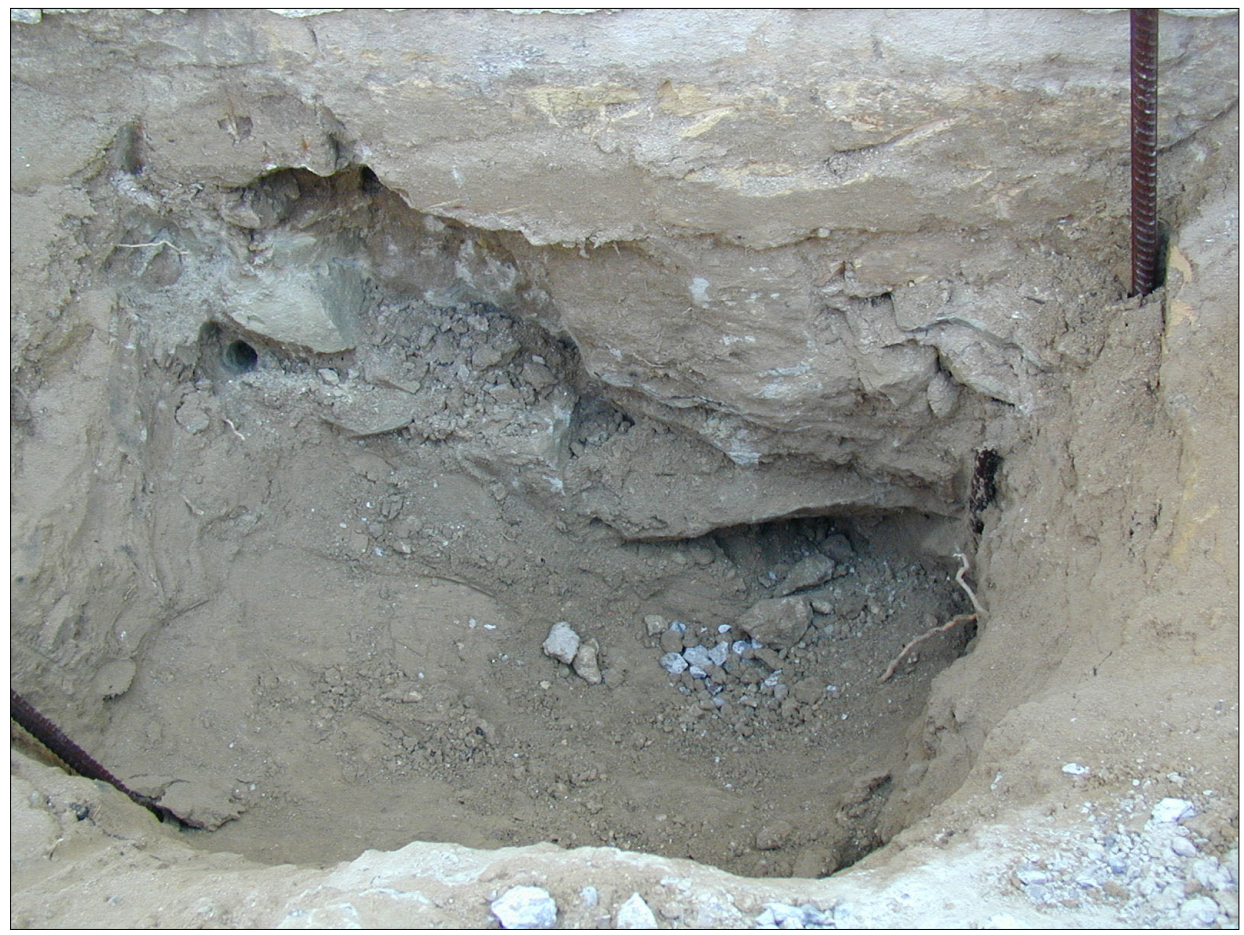

Figure 4-12. PSI Test Pit 7, outside the Ramirez Hospital, showing sandstone foundation.

glass represents two bottles, and both bottles were freeblown. If so, they almost certainly predate 1850 , as mold blowing had become the standard by about 1840 (Adams 1971). In addition, one bottleneck fragment of olive glass, with a mold mark, has been hand-stretched and has an applied lip worked with a lipping tool. This manufacturing technique may have been used any time between about 1840 and 1903, but is most likely to be from the earlier part of that period.

The two test units inside the oldest part of the Ramirez Hospital clearly show that extensive work was done on the foundation of this building; probably at the time it was renovated into the hospital. Although the PSI test pits dug outside the foundations show the same sort of sandstone rubble used to construct the upper walls (Figure 4-12), Test Units 5 and 6 clearly show that a concrete abutment was added to the interior of the foundation, presumably intended to increase stability of the structure.

During the process of renovation, it appears that, as seems to have also been the case in the Stone Cottage, some of the original sediments beneath the floor were removed and replaced with fill. This seems to be especially the case with Test Unit 6 . There were a few nineteenth-century artifacts recovered, especially in the upper two levels of Test Unit 5, and it is possible that some original sediment remains in some areas of the building. However, Test Unit 5 shows that even where original sediments remain, the artifact count dating to the eighteenth and early nineteenth centuries is very low.

\section{The Coffee Pot Café (41SR337)}

The scope of work called for a test unit to be dug inside one of the rooms in the rear of The Coffee Pot Café building (Figure 4-13). This room has a wood-framed shed roof and the walls are structural clay tile. The existing flooring is terrazzo tile. It is possible that the structure may have replaced an earlier $1850 \mathrm{~s}$ structure or may sit atop an $1850 \mathrm{~s}$ refuse dump. The goal of Test Unit 4 was to investigate either of these possibilities.

In addition, a total of 12 shovel tests was excavated in the unpaved courtyard behind the building. When it became possible to excavate additional $1-\mathrm{x}-1-\mathrm{m}$ test units within the courtyard, it was decided to place these units in the vicinity of the shovel tests that had the highest density of nineteenthcentury artifacts (i.e., STs 18 and 19). Test Units 7 and 8 were placed to test this area (Figure 4-13). 


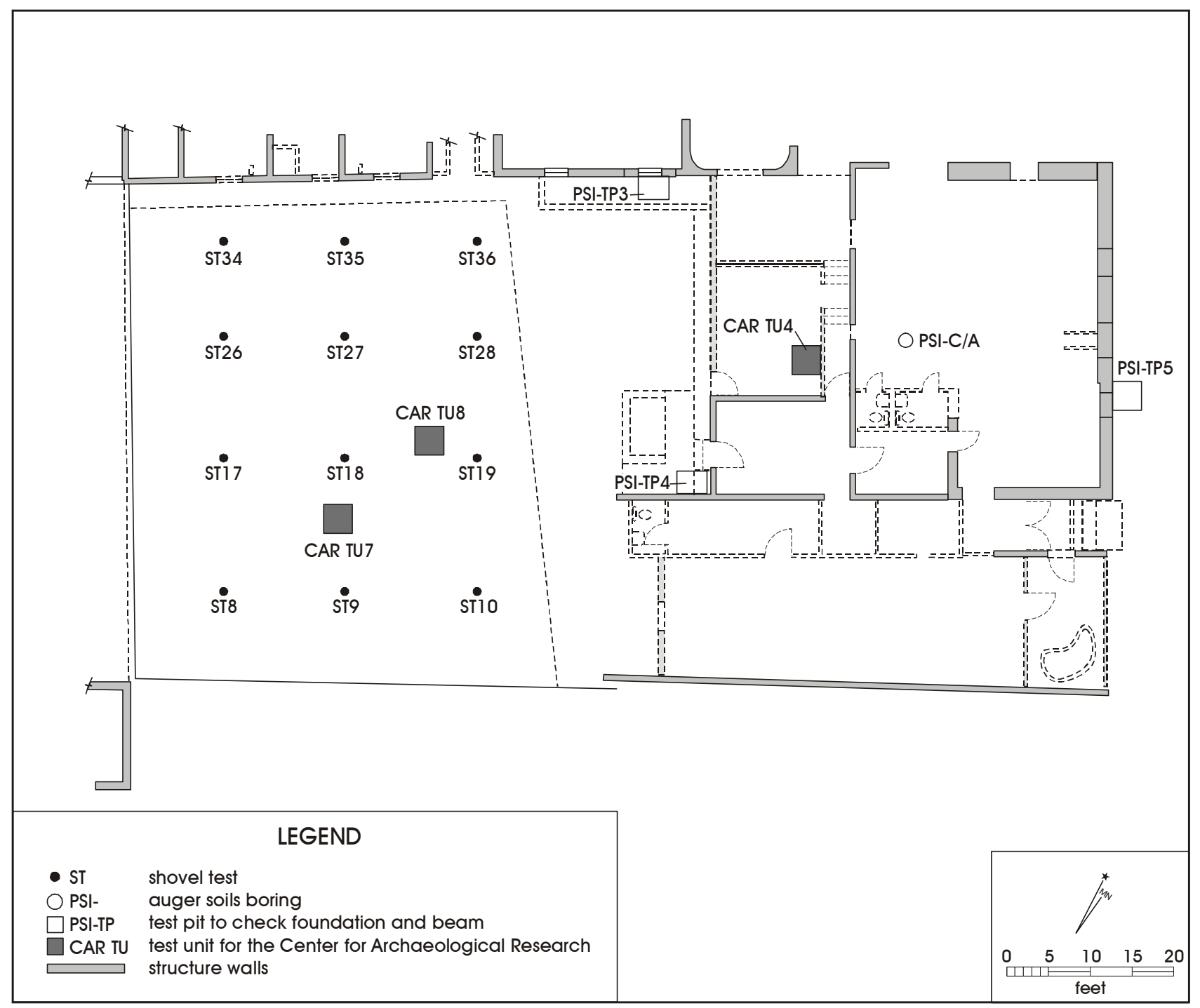

Figure 4-13. Plan map of The Coffee Pot Café (41SR337), showing location of test units, shovel tests, and PSI test pits.

\section{Shovel Tests}

A total of 12 shovel tests was dug in the unpaved part of the courtyard behind The Coffee Pot Café building. These were STs 8-10, 17-19, 26-28, and 34-36. Four of these tests, STs $17,19,27$, and 35, encountered obstructions before their originally intended terminal depths of $70 \mathrm{cmbs}$. ST 17 encountered a limestone boulder at $67 \mathrm{cmbs}$, while STs 19, 27 , and 35 encountered cast iron and/or ceramic pipes at 25,60 , and $38 \mathrm{cmbs}$, respectively. These findings suggest that large portions of this courtyard that will be impacted by several six-inch-wide and six-inch-deep irrigation ditches has already been severely disturbed by older trenching.
Table 4-7 lists the data collected from these shovel tests. Appendix B provides detailed proveniences for each artifact by unit and level. A total of 756 artifacts was recovered from the 12 shovel tests (Table 4-7). Artifact densities steadily increased from Level 1 through Level 3, and peaked in Level 4. The number of artifacts began to decline in Level $5(40-50 \mathrm{cmbd})$ to the point that only 47 artifacts were recovered from Level 7 (60-70 cmbd).

The majority $(76 \%)$ of the artifacts are non-diagnostic, although about one-fourth are temporally diagnostic and help date the occupation of the site (Table 4-7). It is useful to note that the most recent (twentieth-century) materials are 
Table 4-7. Artifacts Recovered from Shovel Tests, by Level and Age Class, at 41SR337

\begin{tabular}{|c|c|c|c|c|c|c|c|c|c|}
\hline $\begin{array}{l}\text { Approximate } \\
\text { Dates }\end{array}$ & Artifact Types & $\begin{array}{rl} & \text { हี } \\
- & 0 \\
\dot{3} & 0\end{array}$ & 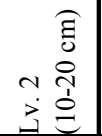 & 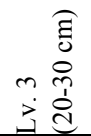 & 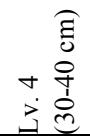 & 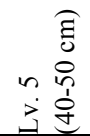 & 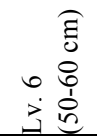 & 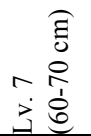 & हैं \\
\hline \multirow{16}{*}{$\begin{array}{l}\text { 18th to Early } \\
19 \text { th Century }\end{array}$} & Lithics & 1 & 0 & 1 & 1 & 5 & 5 & 0 & 13 \\
\hline & Gunflint & & & & & 1 & & & 1 \\
\hline & Unglazed (Unrefined) ceramics & & & 1 & & & 3 & & 4 \\
\hline & Unlgazed: "Roma ware" & & & & 9 & & & & 9 \\
\hline & Tonalá ware & & & & & & 1 & & 1 \\
\hline & Lead glazed-Sandy paste ware & 1 & 1 & 4 & 1 & 4 & 3 & 1 & 15 \\
\hline & Lead glazed-Unidentified & 1 & 1 & 2 & 1 & & & & 5 \\
\hline & \begin{tabular}{|l} 
Lead glazed-Galera \\
\end{tabular} & & & 2 & 2 & & 2 & & 6 \\
\hline & Lead glazed Redware & & & & & & 1 & & 1 \\
\hline & Lead glazed brown on yellow & & & & & & 1 & & 1 \\
\hline & White earthenware (Edge decorated) & & & & & & 1 & & 1 \\
\hline & White earthenware (Handpainted) & & & 4 & 2 & 2 & 1 & 1 & 10 \\
\hline & Glass: Olive & 1 & & 3 & 1 & 2 & 1 & & 8 \\
\hline & Brick, handmade & 2 & 3 & 6 & 7 & 6 & 4 & 4 & 32 \\
\hline & Total 18th to Early 19th & 6 & 5 & 23 & 24 & 20 & 23 & 6 & 107 \\
\hline & $\%$ of Diagnostic Artifacts in Level & $42.9 \%$ & $35.7 \%$ & $60.5 \%$ & $60.0 \%$ & $62.5 \%$ & $71.9 \%$ & $60.0 \%$ & \\
\hline \multirow{13}{*}{ 19th Century } & White earthenware (Unidentified) & & & & 3 & & & & 3 \\
\hline & White earthenware (Undecorated) & & 1 & 4 & 5 & 8 & 2 & 2 & 22 \\
\hline & \begin{tabular}{|l} 
White earthenware (Cut Sponge) \\
\end{tabular} & 1 & 1 & & & 1 & & & 3 \\
\hline & white earthenware (Spatterware) & & & & & & 1 & & 1 \\
\hline & White earthenware (Annular) & & & & 2 & & & & 2 \\
\hline & White earthenware (Transfer) & & & 1 & & 1 & 1 & & 3 \\
\hline & Stoneware & & & & 1 & & & & 1 \\
\hline & Glass: Dark olive ("black") & 1 & & 1 & & & 1 & 1 & 4 \\
\hline & Lamp chimney glass & 2 & & & 2 & 1 & 1 & 1 & 7 \\
\hline & Clothing: Buttons: Ceramic & & & & & & 1 & & 1 \\
\hline & Nails: Cut & & & & & & 2 & & 2 \\
\hline & Total 19th Century & 4 & 2 & 6 & 13 & 11 & 9 & 4 & 49 \\
\hline & $\%$ of Diagnostic Artifacts in Level & $28.6 \%$ & $14.3 \%$ & $15.8 \%$ & $32.5 \%$ & $34.4 \%$ & $28.1 \%$ & $40.0 \%$ & \\
\hline \multirow{3}{*}{$\begin{array}{l}\text { Late 19th to } \\
\text { Early 20th } \\
\text { Century }\end{array}$} & Glass: Clear (purpled) & & & 2 & & & & & 2 \\
\hline & \begin{tabular}{|l|l} 
Total Late 19th to Early 20th \\
\end{tabular} & $\mathbf{0}$ & $\mathbf{0}$ & 2 & $\mathbf{0}$ & $\mathbf{0}$ & $\mathbf{0}$ & $\mathbf{0}$ & 2 \\
\hline & $\%$ of Diagnostic Artifacts in Level & $0.0 \%$ & $0.0 \%$ & $5.3 \%$ & $0.0 \%$ & $0.0 \%$ & $0.0 \%$ & $0.0 \%$ & \\
\hline \multirow{7}{*}{ 20th Century } & Nails: Wire & & 6 & 3 & 2 & 1 & & & 12 \\
\hline & Clothing: Buttons: Plastic & 1 & & & & & & & 1 \\
\hline & White earthenware (Copper luster) & & & 1 & & & & & 1 \\
\hline & Plastic syringe covers & & & 2 & & & & & 2 \\
\hline & Plastic & 3 & 1 & 1 & 1 & & & & 6 \\
\hline & Total 20th Century & 4 & 7 & 7 & 3 & 1 & $\mathbf{0}$ & $\mathbf{0}$ & 22 \\
\hline & $\%$ of Diagnostic Artifacts in Level & $28.6 \%$ & $50.0 \%$ & $18.4 \%$ & $7.5 \%$ & $3.1 \%$ & $0.0 \%$ & $0.0 \%$ & \\
\hline \multicolumn{2}{|c|}{ Total Diagnostic Artifacts } & 14 & 14 & 38 & 40 & 32 & 32 & 10 & 180 \\
\hline
\end{tabular}


Table 4-7. continued...

\begin{tabular}{|c|c|c|c|c|c|c|c|c|c|}
\hline $\begin{array}{c}\text { Approximate } \\
\text { Dates }\end{array}$ & Artifact Types & 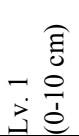 & 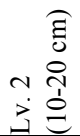 & 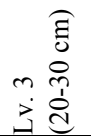 & 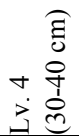 & 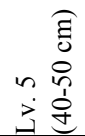 & \begin{tabular}{rl} 
& $\widehat{E}$ \\
0 & 8 \\
0 & 0 \\
$\dot{3}$ & \multicolumn{1}{c}{}
\end{tabular} & 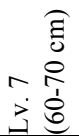 & 苞 \\
\hline \multirow{31}{*}{ Non-diagnostic } & Porcelain & & & & & & & & $\mathbf{0}$ \\
\hline & Figure base & & & & & & 1 & & 1 \\
\hline & Terracotta flower pot & & & & 1 & & & & 1 \\
\hline & Glass: Brown & 2 & 1 & 5 & 1 & 3 & 3 & & 15 \\
\hline & Glass: Aqua & 1 & 1 & 3 & 1 & & & & 6 \\
\hline & Glass: Blue & & & & & 2 & & & 2 \\
\hline & Glass: Green & & 1 & & & & & & 1 \\
\hline & Glass: Clear & 9 & 14 & 11 & 22 & 5 & 3 & 2 & 66 \\
\hline & Glass: Pink & & & & & 1 & & & 1 \\
\hline & Glass: Yellow & & 1 & & & & & & 1 \\
\hline & Clear glass bottle & 1 & & & & 1 & & & 2 \\
\hline & Green glass bottle & & & & & 1 & & & 1 \\
\hline & Window glass & 3 & & & 1 & 14 & & & 18 \\
\hline & Concrete fragments & 2 & & 2 & 9 & 1 & 2 & 3 & 19 \\
\hline & Plaster & 1 & & 3 & 11 & 6 & & 1 & 22 \\
\hline & Mortar & 2 & 3 & 6 & 4 & 2 & 5 & & 22 \\
\hline & Asphalt & & 6 & & & & & & 6 \\
\hline & Tile & 1 & 7 & 6 & 1 & & 2 & 1 & 18 \\
\hline & Ceramic Sewer Pipe & & & & & & 1 & & 1 \\
\hline & Wire: Electircal & 1 & & & & & & & 1 \\
\hline & Misc. Hardware & & 2 & 1 & 1 & 1 & & & 5 \\
\hline & Iron scrap & 5 & 13 & 17 & 7 & 9 & 5 & 6 & 62 \\
\hline & Lead scrap & & 1 & 1 & & & & & 2 \\
\hline & Copper scrap & & & & & 1 & & & 1 \\
\hline & Slate & & 1 & & & 1 & & & 2 \\
\hline & Tar & 3 & 1 & & 2 & 4 & & & 10 \\
\hline & Metal Foil & 3 & & 1 & & & & & 4 \\
\hline & Mica & 6 & 2 & 2 & & 6 & & & 16 \\
\hline & Bone & 7 & 26 & 49 & 72 & 46 & 38 & 24 & 262 \\
\hline & Mussel shell & 1 & & 2 & & 2 & 3 & & 8 \\
\hline & Total Non-diagnostic & 48 & 80 & 109 & 133 & 106 & 63 & 37 & 576 \\
\hline \multicolumn{2}{|l|}{ Total Artifacts } & 62 & 94 & 147 & 173 & 138 & 95 & 47 & 756 \\
\hline
\end{tabular}

common only in Level 2. On the other hand, eighteenth and early-nineteenth-century remains are common in Level 3 through Level 7. Ten of the 13 chipped lithic artifacts from the shovel tests are from Levels 5 and 6. One of these 13 artifacts is a possible gunflint.

The possible gunflint was recovered from Level 5 in ST 28 (Figure 4-14a). This object is made of local chert, but fashioned in a style that is typical of gunflints recovered from Fort St. Louis (Carol Villalobos, personal communication 2003). While the style can be dated to the 1680 s, such items were in common use until the 1840s or 1850s. The depositional context of this artifact is problematic, though, as several nineteenth-century artifacts were recovered in lower excavated levels. It has been speculated that a Spanish soldier or a Native American from one of the Spanish missions located along the Mexican side of the Rio Grande manufactured the possible gunflint. The gunflint does not exhibit the normal wear markings associated with its use, instead, the wear markings are consistent with those of a strike-a-light. The use of this object as a strike-a-light has erased any evidence of its use as a gunflint. 


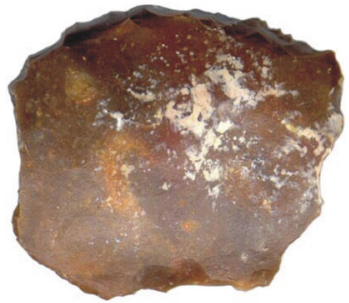

a

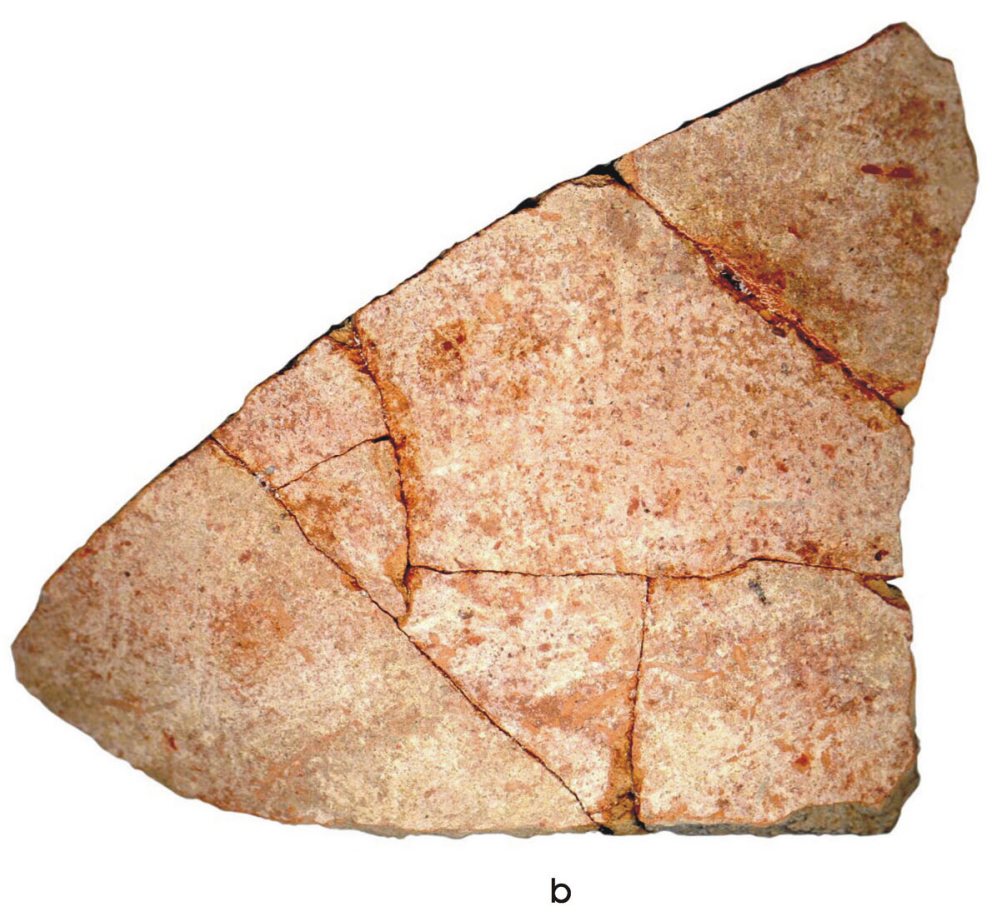

b

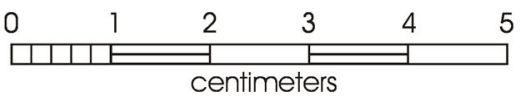

Figure 4-14. Selected Artifacts from shovel tests in 41SR337. (a) possible gunflint; (b) "Roma Ware" sherds.

Shovel Tests 9 and 10 (see Appendix B) each produced fragments of a very fine sandy-paste earthenware that has been designated "Roma ware" for the purposes of this project (Figure 4-14b). The ceramic appears to be manufactured locally from local materials. The sherds exhibit a very dark, almost black, center portion of the paste, with a pink-orange surface on the exterior and interior of the vessel. After reconstruction, the sherds seem to be part of a large bowl, possibly wheel-thrown. No date can be assigned to this type of ceramic at this time. A larger collection of these specimens may allow us to determine if this type of ceramic is truly a previously unrecorded type. Given the high density of eighteenth and early-nineteenth-century artifacts in the courtyard, specifically around STs $9,19,27$, and 28, it was decided that two additional 1-x-1-m test units (TUs 7 and 8 ) would be excavated to investigate the nature of the deposits.

\section{Test Unit 4}

Test Unit 4 was located against the wood-frame staircase along the northeast wall of a room at the back of The Coffee Pot Café building (Figure 4-13). The terrazzo floor and concrete sub-floor were removed prior to excavation. The vertical datum was set $1 \mathrm{~cm}$ above the floor surface.

The uppermost level of the unit encountered a layer of light gray coarse builder's sand with about $50 \%$ pea-sized gravels. The builder's sand continued for $3 \mathrm{~cm}$ into Level 2 (20-23 $\mathrm{cmbd})$. The level was terminated when darker sediments were encountered. The sediments in Level $3(23-33 \mathrm{cmbd})$ were light yellowish-brown (2.5Y6/4) loamy sand, with about $40 \%$ pea-sized gravels and about $20 \%$ fist-sized river cobbles. The Level 4 sediments were similar to those in Level 3 but became much more hard-packed as the depth 
increased. Gravels were fewer, only about $20 \%$, and river cobbles increased to about $30 \%$ of the volume. The sediments in Level $5(43-53 \mathrm{cmbd})$ gradually darkened to a pale brown (10YR6/3) loamy sand that was very hard packed. There were fewer cobbles in this level, except for what appeared to be a line of cobbles parallel to the southwest wall of the unit, looking as if they might have formed the edge of a walkway. A large animal burrow (23 $\mathrm{cm}$ by about $15 \mathrm{~cm}$ ) was encountered next to the northwest wall of the unit, and appeared to go much deeper. Most of Level $6(53-63 \mathrm{cmbd})$ was dominated by $7-15 \mathrm{~cm}$ river cobbles (ca. 30\%) and gravels (ca. 30\%). The sediments in this level became a light brownish-gray (10YR6/2) sandy clay loam that was extremely hard packed. Most of the sediments in Level 7 (63-73 cmbd) and Level 8 (73-83 cmbd) consisted of large (7-15 cm in size) river cobbles (ca. 60\%) and gravels (20\%). The large river cobbles and gravels stopped at about $85-87 \mathrm{cmbd}$, and the sediments changed to a loose, light gray (10YR7/2) clay loam with only about $20 \%$ smaller $(5-10 \mathrm{~cm})$ river cobbles. The level was taken to $93 \mathrm{cmbd}$ and excavation was terminated. No cultural material was recovered from this level.

A total of 484 artifacts was recovered from Test Unit 4 (Table 4-8). The vertical distribution of the artifacts indicates two peaks, one in Level 3 and another in Level 5. Rather unusually, however, the Level 3 materials are dominated by eighteenth and early-nineteenth-century temporally diagnostic artifacts while twentieth-century materials are more common in Level 5 and Level 4. Chipped stone flakes are also more common in Level $3(n=6)$ than in higher $(n=2)$ or lower $(\mathrm{n}=2)$ levels. The concentration of later materials in deeper contexts may be the product of animal burrowing noted within the unit. The deeper levels have few diagnostic artifacts and, therefore, temporal trends cannot be reliably established. Nonetheless, two gaming pieces fashioned from fragments of ironstone pottery were recovered in Level 6 (Figure 4-15, a and b). Information concerning the use of these pieces has not been found. The presence of sponge ware and annular ware pieces indicates a nineteenth-century association, but much of the material collected from the level is non-diagnostic.

\section{Test Unit 7}

Test Unit 7 was placed near shovel tests in the courtyard of 41SR337 in order to further test an area where large numbers of artifacts had been located during shovel testing (Figure 4-13). Test Unit 7 was placed about $1 \mathrm{~m}$ east of ST 18 because of the large number of eighteenth and earlynineteenth-century artifacts recovered from this shovel test (see Appendix B). The vertical datum was set $3 \mathrm{~cm}$ above the north corner of the unit.

The ground surface was completely covered with native grasses. The sediments in the first $10 \mathrm{~cm}$ (Level 1) were a pale brown (10YR6/3) sandy clay loam. Level 2 (10-20 cmbd) was still part of the upper layer of soils that were tilled approximately five years prior to this project. Roughly $10 \%$, by volume, of the sediments in Level $3(20-30 \mathrm{cmbd})$ consisted of small rocks. In Level 4 , the sediments became darker to a pale brown (10YR6/3) sandy clay loam with few rocks. The level showed some disturbance by an ant colony near a lens of charcoal located in the south corner of the unit. Doubtless, some bioturbation of artifacts has occurred as a result of this ant colony. Sediments in Level 5 (40-50 cmbd) continued as above, except for an increase to about $10 \%$ pea-sized gravel. Near the bottom of the level, a dense area of charcoal and burned clay appeared in the western corner of the unit. Sediments in Level 6 (50-60 cmbd) remained the same as the previous two levels except for the 5-cm-thick lens of dark grayish-brown (2.5YR4/2) charcoal and burned clay that continued from the layer above. At the bottom of the level, soils became noticeably more compact and somewhat lighter. Sediments in Level 7 (60-70 cmbd) were very compact pale brown (10YR6/3) sandy clay loam with some areas of somewhat softer sediments. Almost immediately after Level $8(70-80 \mathrm{cmbd})$ began, the sediments changed to a soft, light yellowishbrown (10YR6/4) sandy clay loam. At the bottom of the level, a large stone was uncovered. In Level 9 (80-90 cmbd), sediments continued as in the previous level, but a concentration of cobbles, fist-sized and larger, littered the bottom of the level. No cultural material was encountered within this level.

The excavation of this test unit produced 658 artifacts (Table 4-9), nearly 200 more specimens than the recovery in Test Unit 4. This quantity supports the observation that the unit was placed in an area of higher artifact density within the courtyard. The vertical distribution of artifacts exhibits two peaks, one in Level 2 and another in Level 5. Artifact densities decrease dramatically below Level 5 .

Some 220 specimens (33\%) out of the Test Unit 7 sample are temporally diagnostic artifacts (Table 4-9). The breakdown of the temporally diagnostic materials indicates that late-nineteenth and twentieth-century materials occur in low numbers $(\mathrm{n}=12)$ and the collection is dominated by late-eighteenth and early-nineteenth-century artifacts. The peak in eighteenth-century materials occurs in Level 4 
Table 4-8. Artifacts Recovered from Test Unit 4, 41SR337

\begin{tabular}{|c|c|c|c|c|c|c|c|c|c|c|}
\hline $\begin{array}{c}\text { Approximate } \\
\text { Dates }\end{array}$ & Artifact Types & 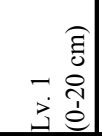 & 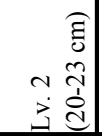 & 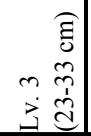 & 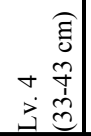 & 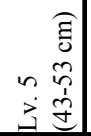 & 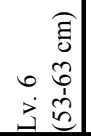 & 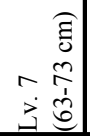 & 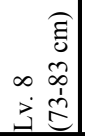 & है \\
\hline \multirow{7}{*}{$\begin{array}{l}18 \text { th to Early } \\
19 \text { th Century }\end{array}$} & Lithics & 2 & & 6 & 2 & & & & & 10 \\
\hline & Unglazed (Unrefined) ceramics & & & 2 & & & & & & 2 \\
\hline & Lead glazed-Unidentified & & & 3 & 1 & 2 & 1 & & & 7 \\
\hline & Glass: Olive & & & & & & 1 & 1 & & 2 \\
\hline & Brick, handmade & & & 34 & 20 & 7 & 1 & 1 & & 63 \\
\hline & Total 18th to Early 19th & 2 & 0 & 45 & 23 & 9 & 3 & 2 & 0 & 84 \\
\hline & $\%$ of Diagnostic Artifacts in Level & $100.0 \%$ & $0.0 \%$ & $76.3 \%$ & $30.3 \%$ & $9.3 \%$ & $23.1 \%$ & $40.0 \%$ & $0.0 \%$ & \\
\hline \multirow{10}{*}{ 19th Century } & White earthenware (Undecorated) & & & 4 & & 2 & 5 & & & 11 \\
\hline & White earthenware (Sponge) & & & & & 1 & 1 & & & 2 \\
\hline & White earthenware (Annular) & & & & & 1 & 2 & & & 3 \\
\hline & White earthenware (Transfer) & & & & & 1 & & & & 1 \\
\hline & Ironstone & & & & & & & 1 & & 1 \\
\hline & Yellow ware & & & 1 & & & & & & 1 \\
\hline & Lamp chimney glass & & & 6 & 5 & & & & & 11 \\
\hline & Nails: Cut & & & & & 4 & & 2 & & 6 \\
\hline & Total 19th Century & 0 & 0 & 11 & 5 & 9 & 8 & 3 & 0 & 36 \\
\hline & $\%$ of Diagnostic Artifacts in Level & $0.0 \%$ & $0.0 \%$ & $18.6 \%$ & $6.6 \%$ & $9.3 \%$ & $61.5 \%$ & $60.0 \%$ & $0.0 \%$ & \\
\hline \multirow{4}{*}{$\begin{array}{l}\text { Late } 19 \text { th to } \\
\text { Early } 20 \text { th } \\
\text { Century }\end{array}$} & Glass: Clear (purpled) & & & 1 & & & & & & 1 \\
\hline & White Earthenware (Decal) & & 1 & & & & & & & 1 \\
\hline & Total Late 19th to Early 20th & 0 & 1 & 1 & 0 & 0 & 0 & 0 & 0 & 2 \\
\hline & $\%$ of Diagnostic Artifacts in Level & $0.0 \%$ & $100.0 \%$ & $1.7 \%$ & $0.0 \%$ & $0.0 \%$ & $0.0 \%$ & $0.0 \%$ & $0.0 \%$ & \\
\hline \multirow{4}{*}{ 20th Century } & White Earthenware (Plain Color Glaze) & & & 2 & & & & & & 2 \\
\hline & Nails: Wire & & & & 48 & 79 & 2 & & & 129 \\
\hline & Total 20th Century & 0 & 0 & 2 & 48 & 79 & 2 & 0 & 0 & 131 \\
\hline & $\%$ of Diagnostic Artifacts in Level & $0.0 \%$ & $0.0 \%$ & $3.4 \%$ & $63.2 \%$ & $81.4 \%$ & $15.4 \%$ & $0.0 \%$ & $0.0 \%$ & \\
\hline \multicolumn{2}{|c|}{ Total Diagnostic Artifacts } & 2 & 1 & 59 & 76 & 97 & 13 & 5 & 0 & 253 \\
\hline \multirow{23}{*}{$\begin{array}{c}\text { Non- } \\
\text { diagnostic }\end{array}$} & Porcelain & & & 2 & & 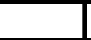 & & & & 2 \\
\hline & Glass: Brown & & & 1 & & & & & 1 & 2 \\
\hline & Glass: Aqua & & & 2 & & & & & & 2 \\
\hline & Glass: Clear & & & 20 & 10 & 8 & & & & 38 \\
\hline & Glass: green & & & 2 & 2 & 1 & & & & 5 \\
\hline & Glass: milk, green & & & 1 & & & & & & 1 \\
\hline & Gaming Piece & & & & & & 2 & & & 2 \\
\hline & Metal Object & & & & & 2 & & & & 2 \\
\hline & Window glass & & & & 4 & 7 & & & & 11 \\
\hline & Other Hardware & & & & & 1 & & & & 1 \\
\hline & Concrete fragments & & & 3 & & 3 & & & & 6 \\
\hline & Plaster & 1 & & & 3 & & & & & 4 \\
\hline & Mortar & & & 1 & & & & & & 1 \\
\hline & Tile & & & 2 & & & 1 & & & 3 \\
\hline & Fence staple & & & & 1 & & & & & 1 \\
\hline & Iron scrap & & 1 & 18 & 12 & & & & & 31 \\
\hline & \begin{tabular}{|l} 
Lithic \\
\end{tabular} & 9 & & 12 & 6 & & 6 & 2 & 2 & 37 \\
\hline & Plastic & & & 1 & & & & & & 1 \\
\hline & Other & & & 10 & & 1 & & & & 11 \\
\hline & Tar & & & & 5 & 9 & & & & 14 \\
\hline & Bone & & & 4 & 1 & 11 & 30 & 7 & 1 & 54 \\
\hline & Mussel shell & & & 1 & & & & 1 & & 2 \\
\hline & Total Non-diagnostic & 10 & 1 & 80 & 44 & 43 & 39 & 10 & 4 & 231 \\
\hline \multicolumn{2}{|c|}{ Total Artifacts } & 12 & 2 & 139 & 120 & 140 & 52 & 15 & 4 & 484 \\
\hline
\end{tabular}




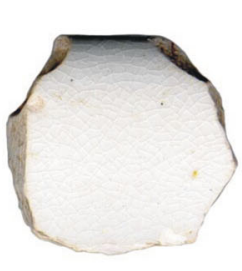

a

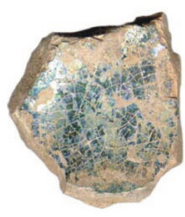

g

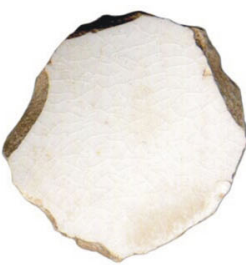

b

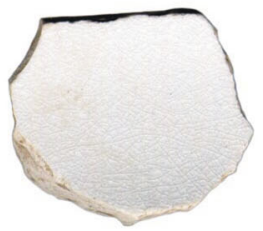

$\mathrm{h}$

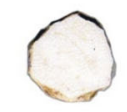

C

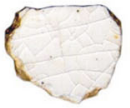

i

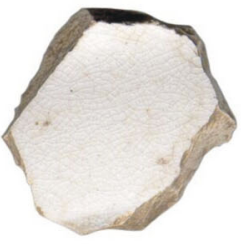

d

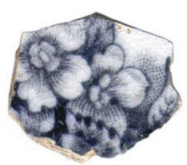

j

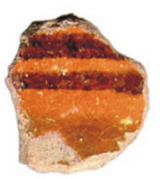

e

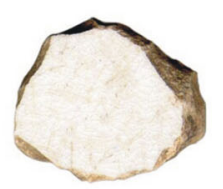

k

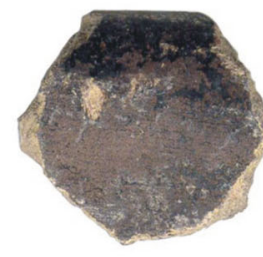

f

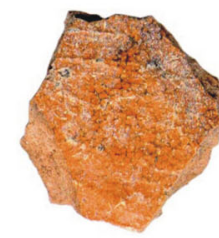

I

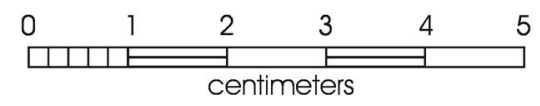

Figure 4-15. Gaming pieces from 41SR337. (a-b) ironstone; (c) undecorated whiteware; (d) undecorated white earthenware; (e) Galera lead-glazed; (f) wheel-thrown unglazed earthenware; (g) unknown type of lead-glazed ware; (h-i) white earthenware; (j) black transferware; (k) undecorated whiteware; (1) unglazed native ware.

suggesting the presence of an isolable occupation/deposition zone at this depth. Levels 5 and 6 continue this trend with the large majority of the artifacts from these levels deriving from the late eighteenth and early nineteenth centuries. Level 4 also exhibits a peak in chipped stone flakes $(n=7)$. A second peak in flakes occurs in Level $7(n=5)$. Nonetheless, the presence of wire nails and clear glass pieces in Levels 4 and 5 suggests that some degree of mixture of deposits has occurred within this unit.

Several unique and/or diagnostic artifacts were recovered from the unit. Some of these are discussed in more detail below. One fragment of Guanajuato polychrome majolica was recovered from Level $2(10-20 \mathrm{cmbd})$ and can be firmly placed within the Nineteenth Century category (Figure 4-16a). Production of this style began during the 1830s (Fox et al. 1997). One fragment of an unidentified lead-glazed ware was recovered (Figure 4-16b). This specimen represents a type of lead glaze decoration that has not been previously encountered in Texas. One small circular ceramic fragment commonly referred to as a gaming piece was also recovered from Level 2 (Figure 4-15c). Four gaming pieces were collected from Level 3 (20-30 cmbd; Figure 4-15, d through g). Each was fashioned from a different type of ceramic - undecorated white earthenware (Figure 4-15d), Galera lead-glazed (Figure 4-15e), wheel-thrown unglazed earthenware (Figure 4-15f), and an unknown type of leadglazed ceramic (Figure 4-15g). Three other gaming pieces found in Level 4 (30-40 cmbd) were fashioned from white earthenware, two of which were undecorated (Figure 4-15, $\mathrm{h}$ and $\mathrm{i}$ ) and the third exhibited black transfer decoration in a floral pattern (Figure 4-15j).

A sherd of Tonalá Burnished ware was recovered from Level 5 (Figure 4-16c). Tonalá is a type of ceramic produced in the town of Tonalá, Jalisco. Deagan (1987:46) states that Tonalá Burnished ceramics have been recovered from eighteenth-century shipwreck cargos. Other interesting ceramics encountered include a fragment of Guanajuato polychrome majolica, a few fragments of an unidentified 
Table 4-9. Artifacts Recovered from Test Unit 7, 41SR337

\begin{tabular}{|c|c|c|c|c|c|c|c|c|c|c|}
\hline $\begin{array}{c}\text { Approximate } \\
\text { Dates }\end{array}$ & Artifact Types & 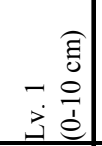 & 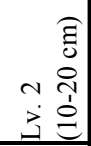 & 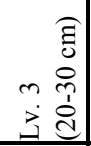 & 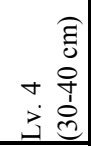 & 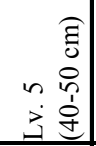 & 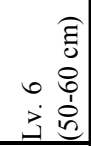 & 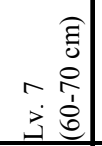 & 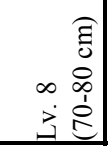 & 矛 \\
\hline \multirow{13}{*}{$\begin{array}{l}\text { 18th to Early } \\
19 \text { th Century }\end{array}$} & Lithics & & 3 & 2 & 7 & 3 & & 5 & 2 & 22 \\
\hline & Unglazed (Unrefined) ceramics & & & & & & 4 & & & 4 \\
\hline & Tonalá Burnished Ware & & & & & 1 & & & & 1 \\
\hline & Lead shot & & & & & & & 1 & & 1 \\
\hline & Lead glazed-Sandy paste ware & & 1 & 3 & 9 & 3 & 4 & & & 20 \\
\hline & Lead glazed-Unidentified & & & & 2 & 6 & & & & 8 \\
\hline & Lead glazed-Galera & & & 2 & 3 & & & & & 5 \\
\hline & White earthenware (Edge decorated) & & & & 1 & & 1 & 1 & & 3 \\
\hline & White earthenware (Handpainted) & & 1 & & 2 & 4 & 1 & & & 8 \\
\hline & Glass: Olive & & 3 & 1 & 6 & 3 & & & & 13 \\
\hline & Brick, handmade & 2 & 8 & 7 & 13 & & 6 & 1 & & 37 \\
\hline & Total 18th to Early 19th & 2 & 16 & 15 & 43 & 20 & 16 & 8 & 2 & 122 \\
\hline & $\%$ of Diagnostic Artifacts in Level & $20.0 \%$ & $47.1 \%$ & $65.2 \%$ & $55.1 \%$ & $45.5 \%$ & $80.0 \%$ & $88.9 \%$ & $100.0 \%$ & \\
\hline \multirow{15}{*}{ 19th Century } & White earthenware (Unidentified) & & & & & 1 & & & & 1 \\
\hline & White earthenware (Undecorated) & 1 & 1 & 8 & 22 & 8 & 1 & & & 41 \\
\hline & White earthenware (Sponge) & & & & 2 & 3 & & & & 5 \\
\hline & White earthenware (Annular) & & & & 2 & 2 & 2 & 1 & & 7 \\
\hline & White earthenware (Transfer) & & & & 2 & & & & & 2 \\
\hline & White earthenware (Flow blue) & & & & 3 & 1 & & & & 4 \\
\hline & Guanajuato Majolica & & 1 & & & 1 & & & & 2 \\
\hline & Ironstone & & 2 & & 1 & 1 & & & & 4 \\
\hline & Copper Luster & & & & & & 1 & & & 1 \\
\hline & Stoneware & & & & 2 & 1 & & & & 3 \\
\hline & Yellow ware & & & & & 2 & & & & 2 \\
\hline & Glass: Dark olive ("black") & & & & 1 & & & & & 1 \\
\hline & Lamp chimney glass & 3 & 10 & & & & & & & 13 \\
\hline & Total 19th Century & 4 & 14 & 8 & 35 & 20 & 4 & 1 & 0 & 86 \\
\hline & $\%$ of Diagnostic Artifacts in Level & $40.0 \%$ & $41.2 \%$ & $34.8 \%$ & $44.9 \%$ & $45.5 \%$ & $20.0 \%$ & $11.1 \%$ & $0.0 \%$ & \\
\hline \multirow{3}{*}{$\begin{array}{l}\text { Late } 19 \text { th to } \\
\text { Early 20th } \\
\text { Century }\end{array}$} & Marbles & & 1 & & & & & & & 1 \\
\hline & Total Late 19th to Early 20th & $\mathbf{0}$ & 1 & $\mathbf{0}$ & $\mathbf{0}$ & $\mathbf{0}$ & $\mathbf{0}$ & $\mathbf{0}$ & 0 & 1 \\
\hline & $\%$ of Diagnostic Artifacts in Level & $0.0 \%$ & $2.9 \%$ & $0.0 \%$ & $0.0 \%$ & $0.0 \%$ & $0.0 \%$ & $0.0 \%$ & $0.0 \%$ & \\
\hline \multirow{8}{*}{ 20th Century } & Crown caps & 1 & & & & & & & & 1 \\
\hline & Pull Tab & 1 & 1 & & & & & & & 2 \\
\hline & White Earthenware (Decal) & & 1 & & & & & & & 1 \\
\hline & 1980 penny & & 1 & & & & & & & 1 \\
\hline & Electrical & 2 & & & & & & & & 2 \\
\hline & Nails: Wire & & & & & 4 & & & & 4 \\
\hline & Total 20th Century & 4 & 3 & 0 & $\mathbf{0}$ & 4 & $\mathbf{0}$ & 0 & $\mathbf{0}$ & 11 \\
\hline & $\%$ of Diagnostic Artifacts in Level & $40.0 \%$ & $8.8 \%$ & $0.0 \%$ & $0.0 \%$ & $9.1 \%$ & $0.0 \%$ & $0.0 \%$ & $0.0 \%$ & \\
\hline \multicolumn{2}{|c|}{ Total Diagnostic Artifacts } & 10 & 34 & 23 & 78 & 44 & 20 & 9 & 2 & 220 \\
\hline
\end{tabular}


Table 4-9. continued...

\begin{tabular}{|c|c|c|c|c|c|c|c|c|c|c|}
\hline $\begin{array}{c}\text { Approximate } \\
\text { Dates }\end{array}$ & Artifact Types & 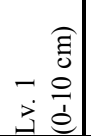 & 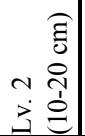 & 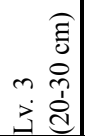 & 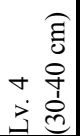 & 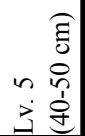 & 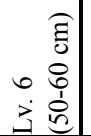 & 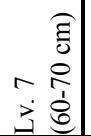 & 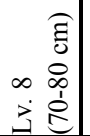 & हैं \\
\hline \multirow{15}{*}{ Non-diagnostic } & Porcelain & & & 1 & & & & & & 1 \\
\hline & Glass: Brown & 1 & 5 & 5 & 1 & & & & & 12 \\
\hline & Glass: Aqua & & & 3 & 1 & 3 & & 2 & & $\overline{9}$ \\
\hline & Glass: Clear & 21 & 21 & 9 & 3 & 3 & & & & 57 \\
\hline & Gaming Piece & & 1 & 4 & 3 & 1 & & & & 9 \\
\hline & Window glass & 2 & 98 & 22 & & & 3 & & & 125 \\
\hline & Other Hardware & 1 & & & & & & & & 1 \\
\hline & \begin{tabular}{|l} 
Plastic \\
\end{tabular} & & 1 & & & & & & & 1 \\
\hline & Mortar & & & & 1 & & & & & 1 \\
\hline & \begin{tabular}{|l|} 
Tile \\
\end{tabular} & & & & 1 & & & & & 1 \\
\hline & Mica & & 16 & & & 3 & & & & 19 \\
\hline & Other & 1 & 3 & 1 & 1 & & & & & 6 \\
\hline & Bone & 8 & 9 & 8 & 12 & 133 & 19 & 2 & & 191 \\
\hline & Mussel shell & & & & & 3 & & 2 & & 5 \\
\hline & Total Non-diagnostic & 34 & 154 & 53 & 23 & 146 & 22 & 6 & 0 & 438 \\
\hline \multicolumn{2}{|l|}{ Total Artifacts } & 44 & 188 & 76 & 101 & 190 & 42 & 15 & 2 & 658 \\
\hline
\end{tabular}

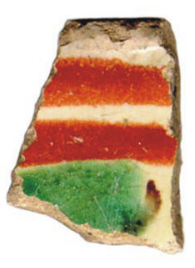

a

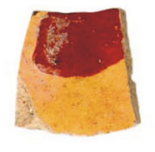

b

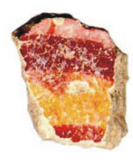

C

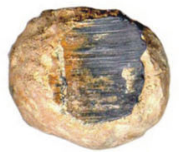

d

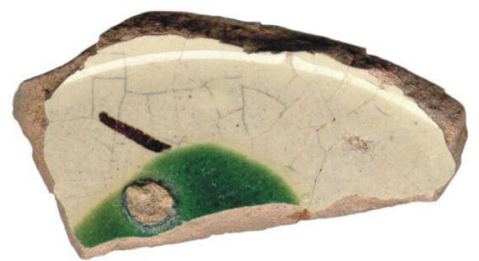

e

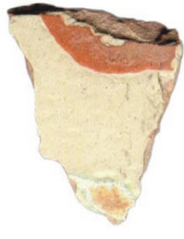

f

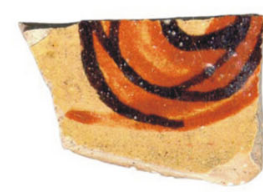

g

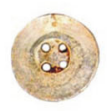

h

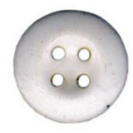

i

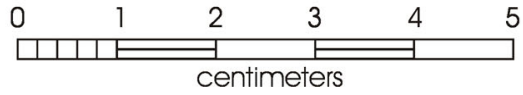

Figure 4-16. Selected artifacts from the test units in 41SR337. (a) Guanajuato majolica fragment; (b) unknown type of lead-glazed ceramic; (c) Tonalá Burnished ware; (d) lead shot with impact scar; (e) San Diego polychrome majolica; (f) unknown majolica; (g) unidentified lead-glazed ceramic; (h) handmade shell button; (i) ceramic button. 
lead-glazed ware, and a gaming piece made on undecorated whiteware (Figure 4-15k).

Of great interest is a lead musket ball recovered from Level 7 (60-70 cmbd). The lead musket ball shows a distinct impact scar, indicating it has been fired (Figure 4-16d). Due to this expansion, the diameter of the ball (i.e., caliber) cannot be determined; however, the weight of 21.5 grams (331 grains) suggests at least a .50-caliber weapon. Muzzle loading firearms such as the one that fired the recovered lead ball continued in use throughout the Mexican-American War and the Civil War.

\section{Test Unit 8}

Test Unit 8 was placed about $3 \mathrm{~m}$ north of Test Unit 7 (Figure 4-13). The unit was placed in this location to further test the area with shovel tests with the highest artifact counts dating to the nineteenth century and earlier. The vertical datum was placed $2 \mathrm{~cm}$ above ground surface at the north corner.

Ground surface in this unit was covered with native grasses. The sediments were soft, olive-brown (2.5Y4/4) sandy clay loam. This level was part of the approximate 20 -cm-deep surface that was tilled about five years prior to the project. Level 2 (10-20 cmbd) sediments were soft, olive-brown $(2.5 \mathrm{Y} 4 / 4)$ sandy clay loam. The sediments in Level 3 (20$30 \mathrm{cmbd}$ ) were composed of a light grayish-brown (10YR6/ 2) sandy loam. The sediments encountered in Level 4 (30$40 \mathrm{cmbd}$ ) were composed of a grayish-brown (10YR5/2) sandy clay loam. This soil continued through Level 7 (60$70 \mathrm{cmbd})$. Most of Level 8 (70-80 cmbd) consisted of the same soil as the previous level, but in the northern and northeastern parts of the unit was a light yellowish-brown (2.5YR6/4) sandy loam. Charcoal was mixed with the sediments. This level appeared to mark the edge of a refuse pit that seemed to extend throughout the rest of the unit. The refuse pit continued through Level 12 (Figure 4-17). Excavation of this unit was terminated at the bottom of Level $12(110-120 \mathrm{cmbd})$ due to OSHA standards. It is not known how much deeper the feature extends.

The excavation of this test unit produced 953 artifacts (Table 4-10). As in the case of Test Unit 7, this quantity supports the observation that the unit was placed in an area of higher artifact density within the courtyard. The vertical distribution of artifacts exhibits three peaks, one in Level 5, another in Level 8, and a deeper one in Level 10. Artifact densities decrease dramatically only below Level 11 .
A large number of temporally diagnostic specimens have been recovered from this unit $(n=381,40 \%$; Table 4-10). As in the previous unit (TU 7), the breakdown of the temporally diagnostic materials indicates that late-nineteenth and twentieth-century materials occur in low numbers $(\mathrm{n}=22$, $6 \%$ ) and the collection is dominated by eighteenth and nineteenth-century artifacts. Peaks in eighteenth-century materials occur in Levels 1, 7 and 10, where diagnostic materials constitute between $62.5-75 \%$ of the total number of temporal diagnostics. Chipped lithic artifacts concentrate between Levels 4 and 7 and in Level 12. The presence of clear and brown glass and window glass throughout the deposits suggests that some degree of mixing of deposits may have occurred.

Of the diagnostic items recovered, three fragments of San Diego polychrome majolica came from Level 5 (40-50 cmbd; Figure 4-16e). This style of majolica was manufactured between 1770 and 1800 (Fox et al. 1997). An unknown type of majolica was recovered during excavation of Level 6 (50-60 cmbd; Figure 4-16f). This fragment exhibits an orangey-pink paste, with a cream colored tin

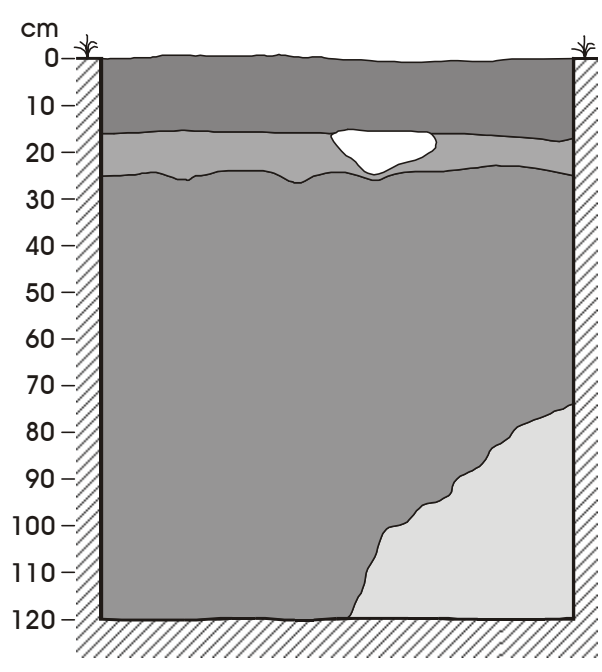

FCR

olive brown (2.5Y4/4) sandy clay loam (disturbed by tiller) soft pale brown (10YR6/2) sandy loam grayish brown (10YR5/2) sandy clay loam light yellowish brown (2.5Y6/4) sandy loam unexcavated

Figure 4-17. Profile of northwest wall of Test Unit 8 at 41 SR337. 
Table 4-10. Artifacts Recovered from Test Unit 8, 41SR337

\begin{tabular}{|c|c|c|c|c|c|c|c|c|c|c|c|c|c|c|}
\hline $\begin{array}{c}\text { Approximate } \\
\text { Dates }\end{array}$ & Artifact Types & 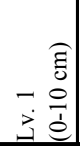 & 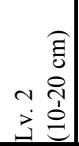 & 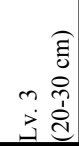 & 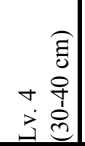 & 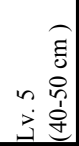 & 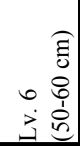 & 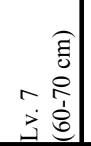 & 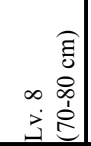 & 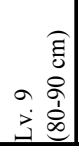 & $\begin{array}{rl} & \widehat{\varepsilon} \\
& 8 \\
\circ & 8 \\
\vdots & \vdots \\
3 & 0\end{array}$ & $\begin{array}{rl} & \widehat{\varepsilon} \\
& 0 \\
0 & 0 \\
\vdots & 0 \\
3 & 0\end{array}$ & 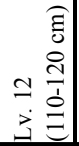 & है \\
\hline \multirow{16}{*}{$\begin{array}{l}\text { 18th to Early } \\
\text { 19th Century }\end{array}$} & Lithics & & 1 & & 3 & & & 4 & 1 & 2 & & & 3 & 17 \\
\hline & Unglazed (Unrefined) ceramics & & 1 & & 1 & & 1 & 1 & 3 & & & & & 7 \\
\hline & Tonalá Burnished Ware & & & & & & & & & & & & & 1 \\
\hline & Majolica-Unknown & & & & & & 1 & & 1 & & & & & 2 \\
\hline & \begin{tabular}{|l|} 
San Diego Polychrome Majolica \\
\end{tabular} & & & & & 3 & & & & & & & & 3 \\
\hline & Black Lusterware & & & & & & 1 & & & & & & & 1 \\
\hline & Lead glazed-Sandy paste ware & 1 & 2 & 1 & & 3 & 2 & & 16 & 11 & & 11 & 2 & 49 \\
\hline & Lead glazed-Brown on yellow & & & & & 1 & & 1 & & & & & & 2 \\
\hline & Lead glazed-Unidentified & & & & & & & 1 & & 2 & 3 & & & 6 \\
\hline & Lead glazed-Galera & & & 4 & 2 & 13 & 16 & 6 & 13 & 4 & 8 & & & 66 \\
\hline & White earthenware (Edge decorated) & & & & & 1 & & & & . & & & & 1 \\
\hline & White earthenware (Handpainted) & & & & 2 & 2 & & & 2 & 2 & 3 & 3 & & 14 \\
\hline & Glass: Olive & & & & 2 & 2 & 4 & 2 & 2 & 3 & 1 & 2 & & 18 \\
\hline & Brick, handmade & 2 & 1 & & & 1 & 5 & 3 & & 1 & & & & 13 \\
\hline & Total 18th to Early 19th & 3 & 5 & 5 & 11 & 28 & 30 & 18 & 38 & 25 & 15 & 17 & 5 & 200 \\
\hline & $\%$ of Diagnostic Artifacts in Level & $75.0 \%$ & $45.5 \%$ & $20.0 \%$ & $47.8 \%$ & $57.1 \%$ & $66.7 \%$ & $75.0 \%$ & $43.2 \%$ & $50.0 \%$ & $62.5 \%$ & $53.1 \%$ & $83.3 \%$ & \\
\hline \multirow{15}{*}{ 19th Century } & White earthenware (Unidentified) & & & & & 1 & & & . & 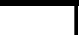 & & 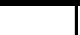 & & 1 \\
\hline & White earthenware (Undecorated) & & & 5 & 5 & 11 & 14 & 3 & 27 & 10 & 8 & 13 & & 96 \\
\hline & White earthenware (Sponge) & & & 1 & & & 1 & & 1 & 3 & & & & 6 \\
\hline & White earthenware (Annular) & & & 1 & & & & & 1 & $\square$ & & 2 & & 4 \\
\hline & White earthenware (Transfer) & & & & & 2 & & & & 1 & & & & 3 \\
\hline & White earthenware (Flow blue) & & & & & & & & & & & & 1 & 1 \\
\hline & Lusterware & & & & & & & 1 & & & & & & 1 \\
\hline & Ironstone & & 1 & 1 & 1 & 4 & & 1 & 4 & 5 & & & & 17 \\
\hline & Stoneware & & 1 & 2 & & & & & 3 & 1 & & & & 7 \\
\hline & Yellow ware & & 1 & & & 1 & & & & & & & & 2 \\
\hline & Glass: Dark olive ("black") & & 2 & 1 & & 2 & & 1 & 9 & 3 & 1 & & & 19 \\
\hline & \begin{tabular}{|l} 
Lamp chimney glass \\
\end{tabular} & & & 1 & & & & & & & & & & 1 \\
\hline & Nails: Cut & & 1 & & & & & & & & & & & 1 \\
\hline & Total 19th Century & 0 & 6 & 12 & 6 & 21 & 15 & 6 & 45 & 23 & 9 & 15 & 1 & 159 \\
\hline & $\%$ of Diagnostic Artifacts in Level & $0.0 \%$ & $54.5 \%$ & $48.0 \%$ & $26.1 \%$ & $42.9 \%$ & $33.3 \%$ & $25.0 \%$ & $28.3 \%$ & $46.0 \%$ & $37.5 \%$ & $46.9 \%$ & $16.7 \%$ & \\
\hline \multirow{6}{*}{$\begin{array}{l}\text { Late 19th to } \\
\text { Early 20th } \\
\text { Century }\end{array}$} & Glass: Clear (purpled) & & & & & & & & & & & & & 1 \\
\hline & Clothing: Buttons: Machine made & & & & & & & & & 2 & & & & 2 \\
\hline & Marbles & & & & & & & & & & & & & 1 \\
\hline & Hotel ware & & & & & & & & 5 & & & & & 5 \\
\hline & Total Late 19th to Early 20th & 0 & 0 & 1 & 1 & 0 & 0 & 0 & 5 & 2 & 0 & 0 & 0 & 9 \\
\hline & $\%$ of Diagnostic Artifacts in Level & $0.0 \%$ & $0.0 \%$ & $4.0 \%$ & $4.3 \%$ & $0.0 \%$ & $0.0 \%$ & $0.0 \%$ & $5.7 \%$ & $4.0 \%$ & $0.0 \%$ & $0.0 \%$ & $0.0 \%$ & \\
\hline \multirow{4}{*}{ 20th Century } & Crown caps & & & 2 & & & & & & & & & & 3 \\
\hline & Nails: Wire & & & 5 & 5 & & & & & & & & & 10 \\
\hline & Total 20th Century & 1 & 0 & 7 & 5 & 0 & $\mathbf{0}$ & 0 & 0 & 0 & 0 & 0 & 0 & 13 \\
\hline & $\%$ of Diagnostic Artifacts in Level & $25.0 \%$ & $0.0 \%$ & $28.0 \%$ & $21.7 \%$ & $0.0 \%$ & $0.0 \%$ & $0.0 \%$ & $0.0 \%$ & $0.0 \%$ & $0.0 \%$ & $0.0 \%$ & $0.0 \%$ & \\
\hline \multicolumn{2}{|c|}{ Total Diagnostic Artifacts } & 4 & 11 & 25 & 23 & 49 & 45 & 24 & 88 & 50 & 24 & 32 & 6 & 381 \\
\hline
\end{tabular}


Table 4-10. continued...

\begin{tabular}{|c|c|c|c|c|c|c|c|c|c|c|c|c|c|c|}
\hline $\begin{array}{c}\text { Approximate } \\
\text { Dates }\end{array}$ & Artifact Types & 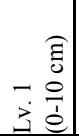 & 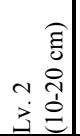 & 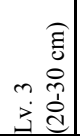 & 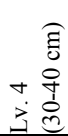 & 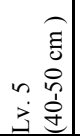 & $\begin{array}{rr} & \widehat{E} \\
& \\
0 & 8 \\
0 & 1 \\
ن & 0 \\
& 1\end{array}$ & 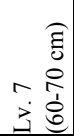 & 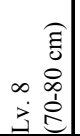 & 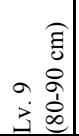 & $\begin{array}{rl} & \widehat{\varepsilon} \\
& 8 \\
\circ & 8 \\
3 & 8 \\
3 & 8\end{array}$ & 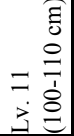 & 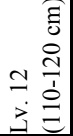 & ฮू \\
\hline \multirow{22}{*}{$\begin{array}{c}\text { Non- } \\
\text { diagnsotic }\end{array}$} & Porcelain & & & & 1 & & & & & 3 & & & & 4 \\
\hline & Glass: Brown & & & 1 & 8 & 5 & & & 6 & 10 & 3 & & & 33 \\
\hline & Glass: Aqua & & 2 & 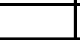 & $\overline{4}$ & 9 & & 3 & 9 & 7 & 2 & & & 36 \\
\hline & Glass: Clear & 3 & 6 & 6 & 8 & 6 & 8 & 1 & 3 & 2 & 3 & 3 & & 49 \\
\hline & Glass: Red & & & & & & & & & & & . & & 1 \\
\hline & Gaming Piece & & & & & & & & & & & 1 & & 1 \\
\hline & Glass: Milk & & & & 1 & & & & & & & & & 1 \\
\hline & Window glass & & & 4 & 3 & & & 1 & 1 & & & & & 9 \\
\hline & Casing: .22 cal. rimfired & & & ( & - & & & & 1 & & & & & 1 \\
\hline & Other Hardware & 1 & 1 & 1 & 1 & & 1 & & + & & & 1 & & 6 \\
\hline & Mica & & & 0 & & & & 1 & 1 & & & & & 2 \\
\hline & Plaster & & 1 & 3 & 1 & & & & & & & & & 5 \\
\hline & Mortar & & & & & 4 & & & & & & 1 & & 5 \\
\hline & Tile & 1 & & & 3 & & & & & & & & & 4 \\
\hline & Fence staple & & & 1 & & & & & & & & & & 2 \\
\hline & Plastic & 1 & & 10 & & & & & & & & & & 11 \\
\hline & Other & & 1 & 1 & 7 & & & & & & & & & 9 \\
\hline & Melted glass & & & & 1 & & & 4 & & & & 1 & & 6 \\
\hline & Tar & & & 5 & & & & & & & & & & 5 \\
\hline & Bone & 5 & 25 & 25 & 44 & 58 & 53 & 35 & 62 & 25 & 94 & 80 & 1 & 507 \\
\hline & Mussel shell & & & & & & & & & 1 & & & & 1 \\
\hline & Total Non-diagnsotic & 11 & 38 & 57 & 82 & 82 & 62 & 45 & 83 & 48 & 102 & 87 & 1 & 698 \\
\hline \multicolumn{2}{|c|}{ Total Artifacts } & 15 & 49 & 82 & 105 & 131 & 107 & 69 & 171 & 98 & 126 & 119 & 7 & 953 \\
\hline
\end{tabular}

glaze. An orange decoration is painted over the glaze. Level $9(80-90 \mathrm{cmbd})$ produced a large fragment of the unidentified lead-glazed ware encountered in Level 7 of this unit and in Test Unit 7 (Figure 4-16g). Examination of the sherds reveals that these specimens appear to come from similar vessels. The paste of the sherds is highly vitrified and dense. It appears to contain some sand or grog tempering. The thickness of the vessel wall is very thin and delicate. Decoration of the sherds begins with a yellow slip, with hand-painted swirling designs in black and red on the interior, and red brush strokes on the exterior. The interior is then coated with a clear lead glaze. This type appears to be previously unrecorded.

One handmade shell button (Figure 4-16h) also was recovered from Level 9, as well as a poorly made ceramic button (Figure 4-16i). The shell button probably dates to before the middle of the nineteenth century (Albert and Kent 1949:59). The ceramic button is so poorly made that one is tempted to assume it is from the earliest period of cheap ceramic button manufacture, which began shortly after 1840
(Epstein and Safro 1991:74). A gaming piece made from unglazed native ware was found in Level 11 (100-110 cmbd; Figure 4-151). This level appeared to be a continuation of the refuse pit first encountered in Level 8.

\section{Monitoring}

Three test pits were excavated in The Coffee Pot Café site by PSI (Figure 4-13). The excavation of the single core drill and hand-auger bore was not observed. PSI Test Pit 3 was located within the planter on the Café patio. Cultural material observed in the backfill of this pit included corroded metal and olive, aqua and clear glass fragments. The type and amount of material was not deemed significant, therefore, none was collected. The wall foundation was approximately $33 \mathrm{~cm}$ in depth from the bottom of the slab to the bottom of the footer.

PSI Test Pit 4 was located on The Coffee Pot Café patio, on the east side of the barbecue pit where the south and east walls of the building meet. The concrete patio was cut, and 
approximately $15 \mathrm{~cm}$ of soil and debris was removed. Below this, another layer of concrete was encountered and removed. Cultural material observed included corroded metal, glass fragments, plastic, and a few small animal bone fragments. No material was collected.

PSI Test Pit 5 was located along the outer north wall of The Coffee Pot Café on Estrella Street. Excavation of this test did not go very deep. The wall foundation sits on top of a limestone layer. The test pit was excavated to approximately $25 \mathrm{~cm}$. No significant cultural material was encountered.

\section{Discussion}

The shovel testing in the courtyard of The Coffee Pot Café site provided a collection of artifacts that spanned from the Colonial period to modern times. The possible gunflint poses several new questions, such as Who was the manufacturer? Was it manufactured during the seventeenth, eighteenth or even early nineteenth century? And, did it originally function as a gunflint? It may not be possible to ever have a full understanding of this piece. The shovel tests also provided a sample of an unidentified earthenware that has been assigned the name "Roma ware." Further investigations of the site could offer more information concerning the verification of this new type.

The shovel tests also revealed that the courtyard has been extensively disturbed by previous trenching for the placement of cast iron and ceramic water and wastewater pipes. These trenches were likely $6-12$ inches wide and were dug to anywhere from 25 to $60 \mathrm{cmbs}$, and even somewhat deeper given that these depths represent to tops of the pipes.

The artifact collection from the shovel tests aided in determining the placement of the two additional test units. The goal was to find nineteenth-century occupational evidence, and the shovel tests provided enough information to make an educated guess concerning test unit placement.

The additional units actually paint a much different picture than just Test Unit 4 would have provided. Test Unit 4 appeared to be fairly disturbed by episodes of construction. The presence of a possible pathway may indicate that the test unit was located outside of the original structure.
Test Unit 7 provided a glimpse of the types of artifacts The Coffee Pot Café courtyard may contain. It is speculated that the lower levels of deposits in the unit may be related to flood events, due to the size of the artifacts recovered and the sediment layering seen in the profile. The presence of ceramic sherds reworked into discs that may represent gaming pieces may indicate that the courtyard was used as a recreational area.

Test Unit 8 appeared to have caught a portion of a trash pit that contained artifacts dating to the eighteenth and early nineteenth centuries. Artifacts were recovered from throughout the unit. Due to OSHA safety regulations, the unit excavation was terminated at $120 \mathrm{cmbd}$; therefore, it is unknown exactly how deep the feature extends. A steep dropoff in artifacts within Level 12 may indicate the bottom of the pit.

Finally, the recovery of 62 chipped stone artifacts (61 debitage and one possible gunflint) is consistent with their occurrence at the two nearby sites 41 SR 210 and 41SR211. The clustering of the materials between Levels 3 and 5 $(n=39,63 \%)$ and their decrease below Level $7(n=9,15 \%)$ indicates that the chipped lithic artifacts co-occur with the eighteenth and early-nineteenth-century materials. 


\section{Chapter 5: Summary and Recommendations}

\section{Introduction}

During February and March of 2003, the Center for Archaeological Research (CAR) of The University of Texas at San Antonio conducted archeological investigations at five sites within the City of Roma National Historic Landmark District in advance of renovations associated with the planned Roma Visitor Complex (RVC). The archeological services were carried out in partial fulfillment of the requirement of the Programmatic Agreement of the Statewide Transportation Enhancement Program, Section 106 of the National Historic Preservation Act, and the Texas Antiquities Code. This Programmatic Agreement includes coordination among the Federal Highway Administration, the Texas Department of Transportation (TxDOT), the Texas Historical Commission (THC), and the Advisory Council on Historic Preservation. CAR conducted this work under contract to Kell Muñoz Architects, a consulting architectural firm in San Antonio. The results of these investigations are for use by the Federal Highway Administration, TxDOT, and the City of Roma for planning purposes.

In advance of construction and renovation activities and for planning purposes, Kell Muñoz Architects called for the performance of a series of geotechnical tasks. Overall, the geotechnical tasks (borings, concrete cores, and excavation units adjacent foundations) were necessary to characterize the present state of the standing structures and also probe the matrix beneath the structures and in the courtyard to determine whether archeological deposits were present that might be disturbed by the installation of utilities (plumbing, electrical, telephone, irrigation) and other improvements. The archeological monitoring of boring holes and geotechnical units and the hand-excavation of 1-x-1-m test units by CAR were designed to identify and assess whether the proposed RVC enhancement project would impact archeological properties and/or deposits eligible to the National Register of Historic Places (NRHP) and/or contributing components to the National Historic Landmark District. It was hopped that with the information about the nature and integrity of archeological properties associated with the standing structures, it would be possible for the City of Roma and its design consultants to avoid adversely impacting the National Historic Landmark.
The town of Roma was formally established six months after the Treaty of Guadalupe Hidalgo in 1848. Five archeological sites within Block 8 of the Historic District are to be impacted by planned renovations associated with the RVC project. They include: the Antonia Sáenz House - 41SR210 (Lot 3), constructed ca. 1884; the Stone Cottage-41SR211 (Lot 2), constructed ca. 1850; the Rafael García-Ramirez House and Store-41SR212 (Lot 1), constructed ca. 1870; the Ramirez Hospital-41SR215 (Lot 8), constructed ca. 1856; and The Coffee Pot Café-41SR337 (Lot 7), original buildings constructed before 1894 .

The archeological services were to consist of monitoring of subsurface excavations associated with geotechnical services, manual excavation of test units within and outside of selected structures dating to circa 1850 , and systematic shovel testing within the courtyard enclosed by the structures associated with the five historic properties within the block. Numerous phases of construction have taken place and modified many of the structures within Block 8 . Because the early days of the founding of the City of Roma were the least well known and documented archeologically, in meetings with the THC, TxDOT, Kell Muñoz Architects, and CAR, it was decided that archeological investigations were to concentrate on structures and portions of the five sites that date to circa 1850 . Additional monitoring and excavation efforts would be concentrated on the identification of $1850 \mathrm{~s}$ deposits within the courtyard bounded by the structures in Block 8. The scope of work included the following specific archeological tasks:

1. Test interior sub-floor areas within the two circa 1850s structures-the Stone Cottage (41SR211) and Ramirez Hospital (41SR215) - for undisturbed cultural materials dating to circa 1850 ;

2. Test for remains of early outbuildings associated with The Coffee Pot Café site (41SR337);

3. Determine the age of the pre-1870s midden identified by Zapata (2002) adjacent the east wall of the Antonia Sáenz House; 
4. Locate any 1850 s refuse dumps within the existing courtyard enclosed by the structures found in Block 8 ; and

5. Monitor the geotechnical borings and test units in previously unexcavated areas for cultural materials dating to around 1850.

Eight 1-x-1-m hand-excavated units were dug on this project. One of these was excavated adjacent to the outside wall of the Antonia Sáenz House. Two units were dug inside of the Stone Cottage and its adjoining kitchen, and two others were excavated through the floor of the Ramirez Hospital. One was excavated through the terrazzo tile floor of a small structure located behind The Coffee Pot Café and the remaining two were dug in the courtyard of The Coffee Pot Café property. In addition, 36 shovel tests were excavated within the courtyard shared by The Coffee Pot Café and the Stone Cottage (41SR337 and 41SR211). Monitoring consisted of observing the excavation of nine test pits dug by PSI in and around the buildings of the project area. These investigations produced an artifact record that offers insight to the occupational history of Block 8 of the Roma Historic District. The material remains of a possible Protohistoric or early Historic occupation of Lots 2, 3, and 7 were identified during these investigations.

\section{Summary of Findings}

\section{Antonia Sáenz Residence (41SR2 10)}

One test unit (TU 1) was excavated along the exterior back wall of the Sáenz residence. A total of 1,607 artifacts was recovered from the unit. The artifact assemblage consists of a variety of objects dating from the late eighteenth through the twentieth centuries. Modern refuse and a few examples of earlier artifacts appeared in the first level. Remaining excavated levels exhibited a mix of eighteenth and nineteenth-century artifacts. Containing primarily lithics and animal bone, Levels 7 and 8, however, represent the only clearly non-mixed levels. The excavations revealed a trash pit along the western edge of the unit. Many of the artifacts recovered during excavation from both within and outside of the pit predate the 1884 construction of the building.

The presence of a peak in chipped stone artifacts in Levels 6 and 7 of the test unit, in combination with large numbers of domesticated faunal remains in Levels $5 b$ and 6 of this unit, suggests that the chipped stone artifacts and the deposits that contain them are Protohistoric or early Historic in age. It is equally possible, however, that the presence of bones of domesticated animals and lithics could indicate mixing of deposits and a lack of depositional integrity. Unfortunately, no independent line of evidence exists to differentiate between these alternatives, although the small number of unidentifiable glass fragments in Level 6 seems to favor the mixed deposit possibility.

Given that the deposit extends under the structure wall but does not continue away from the structure, its limits cannot be determined on the basis of the single test unit excavated by CAR. Nonetheless, the fact that the wall cross-cuts the deposits, and at least two pits appear to have been dug into each other, suggests that the materials have been severely disturbed and have poor associational integrity.

\section{Stone Cottage (41SR211)}

Twenty-four shovel tests and two test units were excavated within the Stone Cottage site. Artifacts recovered from the shovel tests range in date from fairly modern trash (medical and construction) to early-nineteenth-century objects. The north-central area of the courtyard contained a layer of concrete that had been dumped during construction activities. The shovel tests that were terminated at this obstruction suggest that portions of the courtyard were previously disturbed to at least a depth of $59 \mathrm{cmbs}$ (about two feet). The materials derived from the shovel tests in the courtyard indicate that even those units that extended to 70 cmbs contained mixed deposits. The construction activities associated with the Roma Visitor Complex within this courtyard will result in the removal of roughly 4-6 feet (122$183 \mathrm{~cm}$ ) of the deposits. The shovel tests that reached 70 cmbs seem to suggest that the cultural deposits decrease significantly at this depth and may not continue much below $70 \mathrm{~cm}$ below the modern surface.

Two 1-x-1-m test units were hand-excavated within the Stone Cottage building. Test Unit 2, located within the original structure, produced very few artifacts. Of the artifacts collected, the diagnostic materials were consistent with eighteenth and nineteenth-century dates.

Test Unit 3, located within the addition portion of the building, provided similar information as Test Unit 2. The diagnostic material recovered from this unit dates from the eighteenth and nineteenth centuries. The soils encountered in both units appeared to be fill. It is possible that the interior of the structure was cleaned out, filled, and then capped with a concrete floor. 
The few ( $\mathrm{n}=9$ ) chipped stone artifacts, consisting of flakes and a core, found in the shovel tests may represent a continuation of the prehistoric or early historic occupation into this lot. The small collection is distributed throughout Levels 1-7 with no discernible peaks. The chipped stone artifact sample from the two test units is much too small to define statistically valid patterns.

\section{Rafael García-Ramirez House and Store (41SR2 12)}

Two test pits were dug by PSI within the Ramirez Store building. PSI Test Pit 8 resembled the units within the Stone Cottage, exhibiting fill with very few artifacts. No artifacts were collected from this pit. PSI Test Pit 9 was located along the shared wall between the store and the Stone Cottage. Two fragments of early-nineteenth-century hand-painted white earthenware were collected from this pit.

\section{The Ramirez Hospital (41SR2 15)}

Two 1-x-1-m test units were excavated within the Ramirez Hospital. Test Unit 5 contained a total of 209 artifacts. Of interest were fragments of a free-blown glass bottle that predates 1850 . Test Unit 6 produced 133 artifacts, many of which were construction-related materials. A few of the artifacts recovered fell into the Eighteenth to Early Nineteenth Century category.

Evidence of work done on the wall foundation of the building was present in the units and the PSI test pits. It is possible that foundation support was added during the renovation of the hospital. The soil appeared to have been removed adjacent to the foundation and concrete was added for support. The soil was then replaced, allowing some artifacts to become incorporated into the wet concrete.

\section{The Coffee Pot Café (41SR337)}

Three 1-x-1-m test units and 12 shovel tests were excavated within The Coffee Pot Café site (41SR337). Three PSI test pit excavations were monitored. Monitoring did not identify any significant cultural materials. The shovel tests were conducted in the courtyard behind the building. The shovel tests provided abundant evidence of eighteenth to nineteenthcentury occupation. In addition, the shovel tests also identified a series of previous disturbances in the form of trenches housing cast iron and ceramic water and wastewater conduits. The results of the shovel tests also aided in the placement of two test units (TUs 7 and 8) within the courtyard. Test Unit 7 produced numerous eighteenth to nineteenth-century artifacts. Many of the items are very small and are thought to have been deposited by flooding episodes. A total of nine gaming pieces was recovered from this unit. This may indicate the use of the courtyard as a recreational area. Test Unit 8 was placed within a few meters of Test Unit 7. The unit appeared to have caught the edge of a trash pit that contained eighteenth and nineteenth-century cultural materials. The artifacts in Test Unit 7 may have originated from this unit.

Test Unit 4 was located inside the building, in what is believed to have been the area of the original structure. Cultural material recovered from this unit did not offer much information concerning the construction of the building. A possible pathway was located in the lower levels of the unit, and the unit appears to have encountered disturbed areas.

A relatively large number $(\mathrm{n}=62)$ of chipped stone artifacts were recovered in the shovel tests and test units at this site. All but one of the specimens is flaking debris. The exception is a possible gunflint recovered from Level $5(50-50 \mathrm{cmbs})$ of ST 28. The chipped stone artifacts are most common in Levels 3-5 $(n=39,63 \%)$. The gunflint, in combination with the large number of eighteenth and early-nineteenth-century materials within the same levels, suggests that the chipped stone assemblage is of Protohistoric or early Historic age rather than prehistoric. The chipped stone artifacts from the adjoining sites (41SR210 and 41SR211) are most likely part of the same occupation. Clear glass artifacts from within the deposits containing late-eighteenth and early-nineteenthcentury items suggests some degree of disturbance. Nonetheless, the fact that disturbances within this courtyard will be limited to roughly six inches below surface may result in no adverse impact to these deposits that are more abundant in Levels 5-11 (50-110 cmbs).

\section{Recommendations}

Archeological investigations adjacent the back wall of the original Antonia Sáenz House (41SR210) identified heavily disturbed archeological materials extending under the wall of the structure. The mixed deposits have no research value and contribute no research potential to the more complete understanding of this site or the Historic District as a whole. Although no systematic shovel testing occurred in the courtyard of this residence, given that subsurface disturbances within the courtyard are planned to extend only to six inches below surface, it is likely that these disturbances 
will not impact deposits eligible to the NRHP or contributing to the National Historic Landmark District. Therefore, no additional archeological work is recommended within this property in advance of planned renovations.

The excavations conducted within the Stone Cottage site (41SR211) indicated that the deposits within the two rooms tested consist, at least in part, of fill introduced to level the surface before subsequent construction. The cultural materials encountered in the courtyard are highly disturbed. The low density and disturbed/secondary context of the cultural materials encountered at the site severely limits their research potential. Therefore, it is recommended that no additional archeological work be conducted at site 41SR211. It is further recommended that the construction activities be carried out as planned.

The Rafael García-Ramirez House and Store (41SR212) was constructed post 1850 . The monitoring of the excavation of two PSI test pits revealed no undisturbed cultural deposits dating to the $1850 \mathrm{~s}$. Therefore, given the absence of undisturbed cultural deposits dating to the founding of the town of Roma, it is recommended that construction activities on this site proceed as planned.

Stabilization of the Ramirez Hospital (41SR215) walls is unlikely to impact previously undisturbed early-nineteenthcentury cultural deposits, since the concrete abutments added to the interior of the foundation have already disturbed any deposits located near the walls. In addition, the deposits found under the floor appear to represent fill that may have been brought in around the time the complex was renovated into a hospital. Given the mixed context of these deposits, no additional archeological work is recommended for this property. Based on the evidence obtained from the testing of this property, it is further recommended that the construction activities on this property associated with the Visitor Complex proceed as planned.

The excavations conducted within the courtyard of The Coffee Pot Café site (41SR337) identified significant disturbances associated with previous trenching for the installation of water and wastewater conduits. These disturbances appear to criss-cross the courtyard and may have impacted deposits to a depth of at least $59 \mathrm{cmbs}$ in places. Nonetheless, pockets of deposits containing lateeighteenth and early-nineteenth-century materials may exist in the courtyard as indicated by the materials recovered from Test Units 7 and 8 . The materials found in these units indicate some degree of mixing of deposits but most of the intact materials appear to be found between $50 \mathrm{cmbs}$ and $110 \mathrm{cmbs}$. The RVC project-related impacts in this courtyard will be limited to a depth of six inches below surface and will not impact these deposits. Therefore, although the deposits found in Test Units 7 and 8 likely date to period of the founding of the town of Roma, these materials will not be impacted by planned renovation activities. Therefore, no further archeological work is recommended within this site.

Overall, the conclusion resulting from the aforementioned archeological investigations is that areas of substantial construction-related impacts related to the RVC project have no intact cultural deposits. Even areas within the National Historic Landmark District that will be subject to relatively shallow subsurface disturbances retain no intact cultural deposits that would be eligible for nomination to the NRHP or may contribute to the existing National Historic Landmark properties. Finally, the one area where cultural materials may be encountered with limited research value will not be adversely impacted by construction activities.

The material found was a mixture of artifacts that likely date to before, during, and after the period of construction of each of the buildings. Because these artifacts were not preserved in an archeological context that dates to a particular historical period of Roma, and none were recovered from distinct archeological features from such a time period, none of the archeological deposits investigated can be considered to be National Register eligible. 


\section{References Cited}

Adams, J. P.

1971 Bottle Collecting in America. New Hampshire Publishing Company, Somersworth.

Albert, L. S., and K. Kent

1949 The Complete Button Book. Appledore, Stratford, Connecticut.

Campbell, T. N., and T. J. Campbell

1981 Historic Indians of the Choke Canyon Reservoir Surrounding Area, Southern Texas. Choke Canyon Series, No. 1. Center for Archaeological Research, The University of Texas at San Antonio.

Deagan, K.

1987 Artifacts of the Spanish Colonies of Florida and the Caribbean 1500-1800. Volume 1: Ceramics, Glassware, and Beads. Smithsonian Institution Press, Washington, D.C.

Epstein, D., and M. Safro

1991 Buttons. Abrams, New York.

Fox, A. A.

2002 Chapter 9: Artifacts: Section A, Ceramics. In Archaeological investigations at the last Spanish Colonial mission established on the Texas frontier: Nuestra Senora del Refugio (41RF1), Refugio County, Texas, edited by C. L. Tennis, pp. 203-219. Archaeological Survey Report, No. 315, Center for Archaeological Research, The University of Texas at San Antonio, and Archeological Studies Program, Report No. 44, Environmental Affairs Division, Texas Department of Transportation, Austin.

Fox, A., R. Pantermuehl, and D. Potter

1997 The Steward's Key to Historic Ceramics. Office of the State Archeologist, Texas Historical Commission, Austin.

Fox, A. A., K. M. Ulrich, and J. E. Zapata

n.d. The Roma Restoration Project, City of Roma, Starr County, Texas. Center for Archaeological Research, The University of Texas at Austin. In preparation.

Goddard, I.

1979 The Languages of South Texas and the Lower Rio Grande. In The Languages of Native America: Historical and Comparative Assessments, edited by S. Campbell and M. Mithun, pp. 355-389. University of Texas Press, Austin.

Hartle, D. D., and R. L. Stephenson

1951 Archaeological Excavations at the Falcon Reservoir, Starr County, Texas. In River Basin Surveys, prepared for the Smithsonian Institution, Washington, D.C.

Heller, D. D.

2002 Roma-Los Sáenz, TX. The Handbook of Texas Online. <http://www.tsha.utexas.edu/handbook/online/articles/ print/RR/hgr6.html> Accessed March 17, 2003. 
Hester, T. R.

1995 The Prehistory of South Texas. Bulletin of the Texas Archeological Society 66:427-459.

Kendrick, G.

1967 Bottle Fragments Betray Age of Historical Sites. El Palacio 74(2):19-24.

Mahoney, R. B., R. P. Mauldin, and S. A. Tomka

2002 Archeological Data Recovery Excavations along Becerra Creek (41WB556), Webb County, Texas. Archaeological Survey Report, No. 321, Center for Archaeological Research, The University of Texas at San Antonio, and Archeological Studies Program, Report No. 44, Environmental Affairs Division, Texas Department of Transportation, Austin.

Munsey, C.

1970 The Illustrated Guide to Collecting Bottles. Hawthorn Books, New York.

O’Malley, N., L. O. Bobbitt, and D. Scurlock

1976 A Historical and Archeological Investigation of Roma, Texas. Report 20. Office of the State Archeologist, Texas Historical Commission, Austin.

Quigg, J. M., C. Lintz, and S. Wilcox

2000 The Lino Site: A Stratified Late Archaic Campsite in a Terrace of the San Idelfonzo Creek, Webb County, Texas. TRC Technical Report 23756, TRC Mariah Associates, Inc., Austin, and Archeological Studies Program, Report No. 20, Environmental Affairs Division, Texas Department of Transportation, Austin.

Quigg, J. M., S. Pritchard, and G. Smith

2002 The Boiler Site (41WB557): Utilization of an Upland Setting over the Last 4200 Years, Webb County, Texas. TRC Technical Report 27277, TRC Mariah Associates, Inc., Austin, and Report No. 45, Archeological Studies Program, Environmental Affairs Division, Texas Department of Transportation.

Ruecking, F., Jr.

1955 The Coahuiltecan Indians of Southern Texas and Northern Mexico. Unpublished M. A. Thesis, University of Texas at Austin. Manuscript on file, Center for Archaeological Research, The University of Texas at San Antonio.

Salinas, M.

1990 Indians of the Rio Grande Delta: Their Role in the History of Southern Texas and Northeastern Mexico. University of Texas Press, Austin.

Smith and Wesson

2002 Smith and Wesson Celebrates 150 Years as Industry Innovator. <http://www.bestadmktgrp.com/smithwesson.html> Accessed March 19, 2003.

Stelle, L. J.

2001 An Archaeological Guide to Historic Artifacts of the Upper Sangamon Basin. Center For Social Research, Parkland College. <http://virtual.parkland.cc.il.us/ lstelle1/len/archguide/documents/arcguide.htm> Accessed March 28, 2003. 
Swanton, J. R.

1940 Linguistic Material from the Tribes of Southern Texas and Northeastern Mexico. Smithsonian Institution, Bureau of American Ethnology, Bulletin 127. Washington, D.C.

Tyler, R. C.

1973 Santiago Viduarri and the Southern Confederacy. Texas State Historical Association, Austin.

Zapata, J. E.

1997 Alamodome and Abroad: A Composite Inquiry on Toy Marbles. In Archaeology at the Alamodome: Investigations of a San Antonio Neighborhood in Transition, Vol. 3: Artifacts and Special Studies, edited by A. A. Fox, M. Renner, and R. J. Hard, pp. 100-119. Archaeological Survey Report, No. 238. Center for Archaeological Research, The University of Texas at San Antonio.

2002 A Historical Archaeology of Roma, Texas. Unpublished Master's Thesis, Department of Anthropology, University of Texas at San Antonio. Manuscript on file, Center for Archaeological Research, The University of Texas at San Antonio. 



\section{Appendix A: Data from Shovel Tests at 41SR2 11 (Stone Cottage)}


Table A-1. Data from Shovel Tests at 41SR211

\begin{tabular}{|c|c|c|c|}
\hline Level (cmbs) & Sediment & Artifacts & Notes \\
\hline \multicolumn{4}{|c|}{ ST 01} \\
\hline Lv. $1(0-10)$ & $\begin{array}{l}\text { Olive brown }(2.5 \mathrm{Y} 4 / 4) \text { sandy clay loam, } \\
30 \% \text { pea gravels }\end{array}$ & $\begin{array}{l}1 \text { square nail, } 1 \text { flat glass, } 1 \text { milk glass, } 4 \text { clear } \\
\text { glass, } 1 \text { brown glass }\end{array}$ & \\
\hline Lv. $2(10-20)$ & $\begin{array}{l}\text { Olive brown }(2.5 \mathrm{Y} 4 / 4) \text { sandy clay loam, } \\
20 \% \text { pea gravels }\end{array}$ & $\begin{array}{l}1 \text { bone, } 1 \text { porcelain, } 3 \text { wire nails, } 10 \text { clear } \\
\text { glass, } 1 \text { blue glass }\end{array}$ & \\
\hline Lv. $3(20-30)$ & $\begin{array}{l}\text { Light olive brown }(2.5 \mathrm{Y} 5 / 4) \text { sandy clay } \\
\text { loam }\end{array}$ & $\begin{array}{l}1 \text { unglazed earthenware, } 1 \text { wire nail, } 1 \text { olive } \\
\text { glass, } 1 \text { brown glass, iron scrap }\end{array}$ & \\
\hline \multicolumn{4}{|c|}{ Terminated due to PVC pipe through center of unit. } \\
\hline \multicolumn{4}{|c|}{ 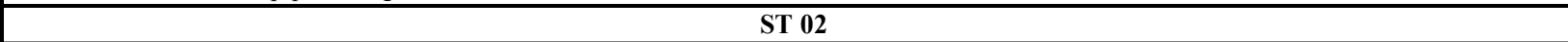 } \\
\hline Lv. $1(0-10)$ & $\begin{array}{l}\text { Olive brown }(2.5 \mathrm{Y} 4 / 4) \text { sandy clay loam, } \\
30 \% \text { pea gravels }\end{array}$ & $\begin{array}{l}3 \text { brown glass, } 1 \text { brick, } 1 \text { hand painted } \\
\text { ceramic, } 21 \text { clear glass, iron scrap }\end{array}$ & \\
\hline Lv. $2(10-20)$ & $\begin{array}{l}\text { Olive brown }(2.5 Y 4 / 4) \text { sandy clay loam } \\
20 \% \text { pea gravels }\end{array}$ & $\begin{array}{l}3 \text { wire nails, } 3 \text { brown glass, } 1 \text { milk glass, } 10 \\
\text { clear glass, } 4 \text { flat glass, iron scrap, } 1 \text { undec } \\
\text { white earthenware }\end{array}$ & \\
\hline Lv. $3(20-30)$ & $\begin{array}{l}\text { Light olive brown }(2.5 \mathrm{Y} 5 / 4) \text { sandy clay } \\
\text { loam }\end{array}$ & $\begin{array}{l}1 \text { plastic, } 1 \text { mussel shell, } 1 \text { blue glass, } 2 \text { brown } \\
\text { glass, } 5 \text { clear glass, } 7 \text { lamp glass, } 1 \text { light bulb } \\
\text { frag, iron scrap }\end{array}$ & $\begin{array}{l}\text { PVC pipe at edge of ST @23-33 } \\
\text { cm bd }\end{array}$ \\
\hline Lv. $4(30-40)$ & $\begin{array}{l}\text { Light olive brown (2.5Y5/6) sandy clay } \\
\text { loam }\end{array}$ & 1 hand painted, 6 clear glass, iron scrap & $\begin{array}{l}\text { Large sandstone rock @34-38 } \\
\text { cm bd }\end{array}$ \\
\hline Lv. 5 (40-50) & \multirow[t]{2}{*}{ Olive yellow (2.5Y6/6) sandy loam } & None & \\
\hline Lv. $6(50-60)$ & & None & \\
\hline Lv. 7 (60-70) & $\begin{array}{l}\text { Light olive brown }(2.5 \mathrm{Y} 5 / 6) \text { sandy clay } \\
\text { loam }\end{array}$ & None & \\
\hline \multicolumn{4}{|c|}{ ST 03} \\
\hline Lv. $1(0-10)$ & \multirow[t]{2}{*}{$\begin{array}{l}\text { Olive brown }(2.5 \mathrm{Y} 4 / 4) \text { sandy clay loam, } \\
20-30 \% \text { pea gravels, charcoal flecks }\end{array}$} & $\begin{array}{l}1 \text { stoneware, } 1 \text { lithic, } 1 \text { plastic, } 1 \text { square nail, } 1 \\
\text { lid liner, } 1 \text { native unglazed earthenware, iron } \\
\text { scrap, } 1 \text { lead glazed, } 1 \text { green glass, } 2 \text { brown } \\
\text { glass, } 14 \text { clear glass, } 1 \text { olive glass, } 1 \text { clear glass } \\
\text { cologne bottle neck }\end{array}$ & \\
\hline Lv. $2(10-20)$ & & $\begin{array}{l}2 \text { bone, } 1 \text { ironstone, } 1 \text { lithic, } 2 \text { mortar, iron } \\
\text { scrap, } 1 \text { square nail, } 2 \text { brown glass, } 1 \text { olive } \\
\text { glass, } 2 \text { flat glass, } 2 \text { aqua glass, } 2 \text { blue glass, } \\
28 \text { clear glass, } 2 \text { lamp glass }\end{array}$ & \\
\hline Lv. $3(20-30)$ & $\begin{array}{l}\text { Light olive brown }(2.5 \mathrm{Y} 5 / 4) \text { sandy clay } \\
\text { loam, }<5 \% \text { pea gravels }\end{array}$ & 1 clear glass, 1 olive glass, 1 fence staple & \\
\hline Lv. $4(30-40)$ & $\begin{array}{l}\text { Light yellowish brown }(2.5 \mathrm{Y} 6 / 4) \text { sandy } \\
\text { loam, }<5 \% \text { pea gravels }\end{array}$ & None & \\
\hline Lv. $5(40-50)$ & \multirow{3}{*}{$\begin{array}{l}\text { Olive yellow (2.5Y6/6)sandy loam, no } \\
\text { gravels }\end{array}$} & None & \\
\hline Lv. $6(50-60)$ & & None & \\
\hline Lv. $7(60-70)$ & & None & \\
\hline \multicolumn{4}{|c|}{ ST 04 } \\
\hline Lv. $1(0-10)$ & $\begin{array}{l}\text { Light yellowish brown }(10 \mathrm{YR} 6 / 4) \text { sandy } \\
\text { clay loam, } 30 \% \text { pea gravels and numerous } \\
\text { small }(<5 \mathrm{~cm}) \text { limestone fragments }\end{array}$ & $\begin{array}{l}1 \text { wire nail, } 1 \text { clear glass jug neck, } 1 \text { olive } \\
\text { glass, } 10 \text { clear glass }\end{array}$ & \\
\hline Lv. $2(10-20)$ & $\begin{array}{l}\text { Grayish brown (10YR5/2) sandy clay loam, } \\
20 \% \text { pea gravels }\end{array}$ & $\begin{array}{l}2 \text { flat glass, } 1 \text { wire nail, } 1 \text { screw top lid, } 3 \\
\text { brown glass, } 11 \text { clear glass }\end{array}$ & \\
\hline
\end{tabular}


Table A-1. continued...

\begin{tabular}{|c|c|c|c|}
\hline Level (cmbs) & Sediment & Artifacts & Notes \\
\hline Lv. $3(20-30)$ & $\begin{array}{l}\text { Pale brown }(10 \mathrm{YR} 6 / 3) \text { sandy clay loam, } 10 \\
\% \text { pea gravels }\end{array}$ & $\begin{array}{l}2 \text { wire nail, } 1 \text { square nail, } 3 \text { aqua glass, } 1 \\
\text { purpled glass, } 1 \text { pink glass, } 17 \text { clear glass, } 3 \\
\text { brown glass }\end{array}$ & \\
\hline Lv. 4 (30-40) & \multirow{4}{*}{$\begin{array}{l}\text { Pale brown (10YR6/3) sandy clay, } 5 \% \text { pea } \\
\text { gravels }\end{array}$} & 2 clear glass & \\
\hline Lv. $5(40-50)$ & & $\begin{array}{l}23 \text { bone, } 1 \text { annular ware, } 3 \text { wire nail, } 1 \text { plastic, } \\
4 \text { olive glass, } 4 \text { clear glass }\end{array}$ & $\begin{array}{l}\text { Lens of white chalky sediment } \\
@ 45-48 \mathrm{~cm} \text { bd }\end{array}$ \\
\hline Lv. $6(50-60)$ & & 51 bone, 1 olive glass, 1 clear glass & \\
\hline Lv. 7 (60-70) & & 1 brown glass, 1 bone & \\
\hline \multicolumn{4}{|c|}{ ST 05} \\
\hline Lv. $1(0-10)$ & $\begin{array}{l}\text { Brown (10YR5/3) sandy clay loam, } 20- \\
30 \% \text { pea gravels, and some broken } \\
\text { limestone building stone }\end{array}$ & $\begin{array}{l}3 \text { clear glass, } 3 \text { lamp glass, } 2 \text { brown glass, } 1 \\
\text { aqua glass, } 2 \text { brick, } 1 \text { lithic, } 1 \text { mortar, } 1 \text { mussel } \\
\text { shell }\end{array}$ & \\
\hline Lv. $2(10-20)$ & $\begin{array}{l}\text { Brown (10YR5/2) clay loam, } 10-20 \% \text { pea } \\
\text { gravels, and some broken bricks and } \\
\text { limestone building stone }\end{array}$ & $\begin{array}{l}1 \text { square nail, } 2 \text { aqua glass, } 1 \text { tile, } 1 \text { brick, } 1 \\
\text { lithic } 7 \text { clear glass }\end{array}$ & \\
\hline Lv. $3(20-30)$ & $\begin{array}{l}\text { Olive brown }(2.5 \mathrm{Y} 4 / 4) \text { sandy clay loam, } 10- \\
20 \% \text { pea gravels, with some rock }(7-8 \mathrm{~cm}) \\
\text { charcoal flecks }\end{array}$ & $\begin{array}{l}\text { Styrofoam pellet and cut nail, } 3 \text { bone, } 3 \text { wire } \\
\text { nail, } 1 \text { brick, } 1 \text { mussel shell, } 1 \text { undec white } \\
\text { earthenware, } 1 \text { stoneware, } 3 \text { aqua glass, } 4 \\
\text { brown glass, } 14 \text { clear glass }\end{array}$ & \\
\hline Lv. $4(30-40)$ & $\begin{array}{l}\text { Light yellowish brown }(2.5 \mathrm{Y} 6 / 4) \text { sandy } \\
\text { clay loam, } 10-20 \% \text { pea gravels }\end{array}$ & $\begin{array}{l}1 \text { brick, } 1 \text { tile, } 1 \text { clear glass, iron scrap, } 1 \\
\text { square nail, } 1 \text { spongeware, } 2 \text { mica }\end{array}$ & \\
\hline Lv. 5 (40-44) & $\begin{array}{l}\text { Light brownish gray (10YR6/4) sandy clay } \\
\text { loam }\end{array}$ & None & \\
\hline \multicolumn{4}{|c|}{ Terminated@ rough concrete slab } \\
\hline \multicolumn{4}{|c|}{ ST 06} \\
\hline Lv. $1(0-10)$ & $\begin{array}{l}\text { Pale yellow (2.5Y7/4) silty loam, } 20-30 \% \\
\text { pea gravel, w/ a few larger rocks }(5-7 \mathrm{~cm}) \text {, } \\
\text { charcoal flecks }\end{array}$ & None & \\
\hline Lv. $2(10-20)$ & $\begin{array}{l}\text { Grayish brown }(2.5 \mathrm{Y} 5 / 2) \text { sandy clay loam, } \\
10-20 \% \text { pea gravel }\end{array}$ & 1 lead glazed ware, 1 clear glass, 1 Galera & \\
\hline Lv. $3(20-30)$ & $\begin{array}{l}\text { Dark grayish brown }(2.5 \mathrm{Y} 4 / 2) \text { sandy clay } \\
\text { loam, } 10-20 \% \text { pea gravels, charcoal flecks }\end{array}$ & $\begin{array}{l}\text { iron scrap, } 3 \text { brown glass, } 1 \text { aqua glass, } 3 \text { clear } \\
\text { glass, } 1 \text { lamp glass, }\end{array}$ & \\
\hline Lv. $4(30-40)$ & $\begin{array}{l}\text { Grayish brown }(2.5 Y 5 / 2) \text { sandy clay loam, } \\
10-20 \% \text { pea gravel and } 1 \text { large burned river } \\
\text { cobble, charcoal flecks }\end{array}$ & $\begin{array}{l}1 \text { brick, } 3 \text { olive glass, } 4 \text { brown glass, } 1 \text { aqua } \\
\text { glass, iron scrap, } 1 \text { undec white earthenware, } 1 \\
\text { unknown white earthenware, } 1 \text { Guanajuato } \\
\text { Polychrome Majolica }\end{array}$ & \\
\hline Lv. $5(40-50)$ & $\begin{array}{l}\text { Light yellowish brown }(2.5 \mathrm{Y} 6 / 3) \text { sandy clay } \\
\text { loam, }<10 \% \text { pea gravels, charcoal flecks }\end{array}$ & $\begin{array}{l}\text { iron scrap, } 4 \text { bone, } 1 \text { spatter ware, } 1 \text { lead } \\
\text { glazed ware, } 1 \text { clear glass, } 1 \text { mortar, } 4 \text { tile }\end{array}$ & \\
\hline Lv. $6(50-60)$ & $\begin{array}{l}\text { Brown }(10 \text { YR5/3) silty loam, }<1 \% \text { pea } \\
\text { gravels, a few } 8-10 \mathrm{~cm} \text { river cobbles, } \\
\text { charcoal flecks }\end{array}$ & 2 bone, 1 clear glass & \\
\hline Lv. 7 (60-70) & $\begin{array}{l}\text { Light yellowish brown (2.5Y6/4) silt, }<5 \% \\
\text { gravels }\end{array}$ & charcoal, 3 lithic & \\
\hline
\end{tabular}


Table A-1. continued...

\begin{tabular}{|c|c|c|c|}
\hline Level (cmbs) & Sediment & Artifacts & Notes \\
\hline \multicolumn{4}{|c|}{ ST 07} \\
\hline Lv. $1(0-10)$ & $\begin{array}{l}\text { Olive brown }(2.5 Y 4 / 4) \text { silty clay loam, } \\
\text { concrete, roots }\end{array}$ & $\begin{array}{l}1 \text { cork, } 1 \text { square nail, } 3 \text { plaster, } 1 \text { clear glass, } 1 \\
\text { brown glass, } 1 \text { green glass, } 1 \text { asbestos tile }\end{array}$ & \\
\hline Lv. $2(10-20)$ & $\begin{array}{l}\text { Dark grayish brown }(2.5 \mathrm{Y} 4 / 2) \text { sandy clay } \\
\text { loam, fragments of mortar, river cobble } \\
(7 \mathrm{~cm})\end{array}$ & $\begin{array}{l}1 \text { gaming piece, } 2 \text { mortar, } 1 \text { crown cap, iron } \\
\text { scrap }\end{array}$ & milk glass gaming piece \\
\hline Lv. $3(20-30)$ & $\begin{array}{l}\text { Dark grayish brown }(2.5 \mathrm{Y} 4 / 2) \text { clay, silty } \\
\text { loam }\end{array}$ & $\begin{array}{l}3 \text { bone, } 1 \text { gaming piece (native earthenware), } 1 \\
\text { brown glass, } 2 \text { brick, } 1 \text { mortar, } 1 \text { lithic }\end{array}$ & $\begin{array}{l}\text { Large mass of mortar from } 16 \text { to } \\
23 \mathrm{~cm} \mathrm{bs}\end{array}$ \\
\hline Lv. $4(30-40)$ & Olive brown (2.5Y4/4)sandy clay loam & $\begin{array}{l}\text { iron scrap, } 1 \text { lead glazed ware, } 1 \text { lithic, } 2 \text { bone, } \\
1 \text { clear glass, } 1 \text { hand painted }\end{array}$ & $\begin{array}{l}\text { Large limestone fragment at 26- } \\
30 \mathrm{~cm}\end{array}$ \\
\hline Lv. $5(40-50)$ & $\begin{array}{l}\text { Brown (10YR5/3) sandy clay loam, with } \\
\text { few large rocks }(\mathrm{ca} .10 \mathrm{~cm}) \text {, charcoal } \\
\text { fragments, charcoal flecks }\end{array}$ & $\begin{array}{l}1 \text { annular ware, } 1 \text { brown glass, } 1 \text { lead glazed } \\
\text { ware, } 1 \text { bone, iron scrap, } 1 \text { lithic }\end{array}$ & $\begin{array}{l}\text { Lens of charcoal @ } 55-58 \mathrm{~cm} \mathrm{bs,} \\
\text { large limestone rock from 57-65 } \\
\mathrm{cm} \text { bs }\end{array}$ \\
\hline Lv. $6(50-60)$ & $\begin{array}{l}\text { Grayish brown } 10 \mathrm{YR} 5 / 2) \text { sandy clay loam, } \\
\text { considerable charcoal, and small }(\mathrm{ca} .5 \mathrm{~cm}) \\
\text { burned rock, charcoal flecks }\end{array}$ & None & \\
\hline Lv. 7 (60-70) & $\begin{array}{l}\text { Light yellowish brown (10YR6/4) sandy } \\
\text { clay loam with } 20 \text { percent pea to marble } \\
\text { gravel }\end{array}$ & None & \\
\hline \multicolumn{4}{|c|}{ ST 11} \\
\hline Lv. $1(0-10)$ & \begin{tabular}{|l} 
Olive brown $(2.5 \mathrm{Y} 4 / 4)$ sandy clay loam, 10 \\
$20 \%$ pea gravels, with a few $5-6 \mathrm{~cm}$ cobbles
\end{tabular} & $\begin{array}{l}1 \text { flat glass, } 4 \text { clear glass, } 1 \text { brown glass, } 1 \\
\text { mortar, } 2 \text { bone }\end{array}$ & \\
\hline Lv. $2(10-20)$ & $\begin{array}{l}\text { Olive brown }(2.5 \mathrm{Y} 4 / 4) \text { sandy clay loam, } 5- \\
7 \% \text { pea gravels, a few bricks and broken } \\
\text { rocks }(\text { ca. } 5 \mathrm{~cm})\end{array}$ & $\begin{array}{l}2 \text { plastic, } 1 \text { plaster, } 2 \text { wire nail, } 1 \text { paint chip, } 2 \\
\text { metal chain, } 1 \text { green glass, } 1 \text { brown glass, } 31 \\
\text { clear glass, } 3 \text { lamp glass }\end{array}$ & \\
\hline Lv. $3(20-30)$ & $\begin{array}{l}\text { Olive brown }(2.5 \mathrm{Y} 4 / 4) \text { sandy loam, }<5 \% \\
\text { pea gravels, a few bricks and broken rocks } \\
(\text { ca. } 5 \mathrm{~cm}) \text {, charcoal flecks }\end{array}$ & 1 plastic, iron scrap, 2 flat glass, 4 clear glass, & \\
\hline Lv. $4(30-40)$ & $\begin{array}{l}\text { Light olive brown }(2.5 \mathrm{Y} 5 / 6) \text { sandy loam, } \\
<1 \% \text { pea gravels }\end{array}$ & 1 plaster, 1 metal chain & \\
\hline Lv. $5(40-50)$ & \multirow[t]{3}{*}{ Light olive brown (2.5Y5/6) sandy loam } & None & \\
\hline Lv. $6(50-60)$ & & None & \\
\hline Lv. 7 (60-70) & & None & \\
\hline \multicolumn{4}{|c|}{ ST 12} \\
\hline Lv. $1(0-10)$ & $\begin{array}{l}\text { Olive brown (2.5Y4/4) sandy loam, } 10- \\
20 \% \text { pea gravels, bits of concrete, and a few } \\
\text { limestone chunk }\end{array}$ & 2 brown glass, 20 clear glass, 2 flat glass & \\
\hline Lv. $2(10-20)$ & Light brown (2.5Y6/4) loamy sand & $\begin{array}{l}1 \text { plastic tube, } 3 \text { green glass, } 3 \text { brown glass, } 3 \\
\text { clear glass }\end{array}$ & \\
\hline Lv. $3(20-30)$ & $\begin{array}{l}\text { Olive brown (2.5Y4/4) sandy loam, } 5 \% \text { pea } \\
\text { gravels }\end{array}$ & None & \\
\hline
\end{tabular}


Table A-1. continued...

\begin{tabular}{|c|c|c|c|}
\hline Level (cmbs) & Sediment & Artifacts & Notes \\
\hline Lv. $4(30-40)$ & \multirow[t]{3}{*}{ Light brown (2.5Y6/4) sandy loam } & 3 clear glass, 1 flat glass & \\
\hline Lv. $5(40-50)$ & & None & \\
\hline Lv. 6(50-58) & & Glass marble, 1 lithic & \\
\hline \multicolumn{4}{|c|}{ Terminated at 55 to $58 \mathrm{~cm}$ bs, encountered concrete mass } \\
\hline \multicolumn{4}{|c|}{ 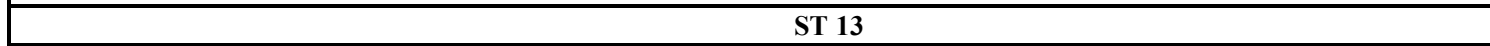 } \\
\hline Lv. $1(0-10)$ & $\begin{array}{l}\text { Olive brown }(2.5 \mathrm{Y} 4 / 4) \text { sandy clay loam, } \\
20 \% \text { pea gravels, grass roots }\end{array}$ & $\begin{array}{l}5 \text { brick, } 2 \text { foil, } 1 \text { plastic, } 1 \text { double headed wire } \\
\text { nail, } 1 \text { wire nail, } 9 \text { clear glass, } 2 \text { brown glass, } 1 \\
\text { porcelain }\end{array}$ & \\
\hline Lv. $2(10-20)$ & Pale brown (10YR6/3) sandy loam & 2 brick, 12 clear glass, 1 porcelain & \\
\hline Lv. $3(20-30)$ & $\begin{array}{l}\text { Light yellowish brown }(2.5 \mathrm{Y} 6 / 4) \text { sandy } \\
\text { loam }\end{array}$ & $\begin{array}{l}1 \text { bone, } 1 \text { brown glass, } 2 \text { clear glass, } 1 \text { square } \\
\text { nail, } 3 \text { brick, } 2 \text { mortar, } 1 \text { button }\end{array}$ & \\
\hline Lv. $4(30-40)$ & Pale yellow (2.5Y7/4) sandy loam & $\begin{array}{l}1 \text { transfer ware, } 1 \text { clear glass, } 1 \text { brown glass, } 1 \\
\text { square nail, iron scrap }\end{array}$ & \\
\hline Lv. $5(40-50)$ & $\begin{array}{l}\text { Hard-packed light gray }(10 Y 7 / 2) \text { sandy } \\
\text { loam }\end{array}$ & none & \\
\hline Lv. $6(50-60)$ & $\begin{array}{l}\text { Very hard-packed olive yellow (2.5Y6/6) } \\
\text { sandy loam }\end{array}$ & none & \\
\hline Lv. $7(60-70)$ & Pale yellow (2.5Y7/4) sandy loam & none & \\
\hline \multicolumn{4}{|c|}{ ST 14} \\
\hline Lv. $1(0-10)$ & $\begin{array}{l}\text { Light brown }(2.5 \mathrm{Y} 6 / 4) \text { sandy clay loam, } 20- \\
30 \% \text { pea gravel increasing near bottom of } \\
\text { level }\end{array}$ & $\begin{array}{l}1 \text { plastic, } 1 \text { terra cotta, iron scrap, } 1 \text { lithic, } 3 \\
\text { brick, } 2 \text { plaster, } 41 \text { clear glass, } 1 \text { lamp glass, } 2 \\
\text { brown glass }\end{array}$ & \\
\hline Lv. $2(10-20)$ & $\begin{array}{l}\text { Light brownish gray }(10 \mathrm{YR} 6 / 2) \text { sandy clay } \\
\text { loam, } 30 \% \text { pea gravel }\end{array}$ & $\begin{array}{l}1 \text { plastic bag, } 2 \text { wire nail, } 1 \text { screw, } 1 \text { lid liner, } \\
\text { iron scrap, } 1 \text { rubber seal, } 2 \text { blue glass, } 49 \text { clear } \\
\text { glass, } 11 \text { lamp glass, } 5 \text { mortar, } 15 \text { mica, } 3 \\
\text { lithic }\end{array}$ & \\
\hline Lv. $3(20-30)$ & $\begin{array}{l}\text { Brown (10YR5/3) sandy clay loam, } 20 \% \\
\text { pea gravel and ca. } 10 \% \text { small }(1-5 \mathrm{~cm}) \\
\text { pieces of brick, mortar, and crushed } \\
\text { limestone }\end{array}$ & $\begin{array}{l}2 \text { mica, } 1 \text { lithic, } 4 \text { brick, } 1 \text { tile, } 2 \text { mortar, } 1 \\
\text { plaster, } 2 \text { barbed wire, } 1 \text { square nail, } 3 \text { iron } \\
\text { scraps, } 1 \text { twist-tie, } 1 \text { zinc lid, } 1 \text { mirrored glass, } \\
1 \text { melted glass, } 26 \text { clear glass, } 5 \text { lamp glass }\end{array}$ & \\
\hline Lv. $4(30-40)$ & $\begin{array}{l}\text { Grayish brown }(10 \mathrm{YR} 5 / 2) \text { sandy loam, } \\
20 \% \text { pea gravels }\end{array}$ & $\begin{array}{l}9 \text { plastic fragments, } 1 \text { brick, } 1 \text { hand painted } \\
\text { ware, } 1 \text { plaster, } 1 \text { mica, } 31 \text { clear glass, } 1 \text { glass } \\
\text { syringe, } 1 \text { glass single use vial, } 6 \text { lamp glass, } \\
\text { iron scrap, } 2 \text { iron shoehorns }\end{array}$ & \\
\hline Lv. $5(40-50)$ & $\begin{array}{l}\text { Dark yellowish brown }(2.5 \mathrm{Y} 4 / 4) \text { sandy clay } \\
\text { loam }\end{array}$ & $\begin{array}{l}2 \text { plastic, } 1 \text { ironstone, } 1 \text { mica, } 1 \text { pull tab, } 1 \\
\text { finishing nail, } 1 \text { brown glass, } 15 \text { clear glass, } 4 \\
\text { lamp glass, } 2 \text { brick, } 1 \text { plaster, } 1 \text { concrete }\end{array}$ & \\
\hline Lv. 6(50-59) & Brown (10YR5/3) sandy clay loam & $\begin{array}{l}2 \text { plastic, } 1 \text { wire nail, } 1 \text { melted glass, } 1 \text { iron } \\
\text { strap, } 11 \text { clear glass }\end{array}$ & \\
\hline \multicolumn{4}{|c|}{ Terminated@ @ $59 \mathrm{~cm}$ bs, encountered concrete } \\
\hline \multicolumn{4}{|c|}{$\begin{array}{l}\text { ST } 15 \\
\end{array}$} \\
\hline Lv. $1(0-10)$ & $\begin{array}{l}\text { Light brownish gray }(10 \mathrm{YR} 6 / 2) \text { sandy loam } \\
20-30 \% \text { pea gravel with a few larger rocks } \\
(\text { ca. } 5-7 \mathrm{~cm})\end{array}$ & $\begin{array}{l}1 \text { bone, } 1 \text { brick, iron scrap, } 2 \text { plaster, } 8 \text { green } \\
\text { glass, } 1 \text { brown glass, } 13 \text { clear glass, } 1 \text { flat } \\
\text { glass, } 6 \text { clear glass vial frag }\end{array}$ & \\
\hline Lv. $2(10-20)$ & $\begin{array}{l}\text { Light yellowish brown (2.5Y6/4) sandy clay } \\
\text { loam, charcoal flecks }\end{array}$ & $\begin{array}{l}\text { iron scrap, } 2 \text { bone, } 1 \text { undec white earthenware, } \\
4 \text { tar }\end{array}$ & \\
\hline
\end{tabular}


Table A-1. continued...

\begin{tabular}{|c|c|c|c|}
\hline Level (cmbs) & Sediment & Artifacts & Notes \\
\hline Lv. $3(20-28)$ & $\begin{array}{l}\text { Light brownish gray }(2.5 \mathrm{Y} 6 / 2) \text { sandy clay } \\
\text { loam, charcoal flecks }\end{array}$ & $\begin{array}{l}1 \text { brown glass, } 1 \text { butter knife blade (stainless } \\
\text { steel), } 1 \text { mortar, iron scrap, } 1 \text { human molar, } 1 \\
\text { syringe }\end{array}$ & \\
\hline \multicolumn{4}{|c|}{ ST 16} \\
\hline Lv. $1(0-10)$ & \multirow[t]{3}{*}{ Grayish brown (10YR5/2) sandy clay loam } & $\begin{array}{l}9 \text { bone, } 6 \text { pull tab/pop top, } 4 \text { foil, } 7 \text { plastic, } 1 \\
\text { lithic, } 1 \text { brick, } 20 \text { flat glass, } 4 \text { lamp glass, } 1 \\
\text { brown glass, } 1 \text { baby food jar, } 4 \text { clear glass, } 2 \\
\text { electrical wires, } 4 \text { metal straps, } 1 \text { wire nail, } 1 \\
\text { bolt, } 1 \text { brace }\end{array}$ & \\
\hline Lv. $2(10-20)$ & & $\begin{array}{l}5 \text { Styrofoam, } 7 \text { plastic, } 11 \text { flat glass, } 3 \text { lamp } \\
\text { glass, } 1 \text { pull tab, iron scrap }\end{array}$ & \\
\hline Lv. $3(20-30)$ & & $\begin{array}{l}1 \text { clear glass, } 1 \text { flat glass, } 1 \text { plastic, } 1 \text { glass } \\
\text { bead, } 1 \text { electrical wire, } 2 \text { bone }\end{array}$ & \\
\hline Lv. $4(30-40)$ & $\begin{array}{l}\text { Light yellowish brown }(2.5 \mathrm{Y} 6 / 4) \text { sandy } \\
\text { clay loam }\end{array}$ & 1 plastic, 2 clear glass & \\
\hline Lv. $5(40-50)$ & \multirow[t]{3}{*}{ Grayish brown (2.5Y5/2) sandy clay loam } & $\begin{array}{l}2 \text { plastic wrapper, } 2 \text { clear glass, } 1 \text { metal object, } \\
1 \text { burned wood, } 2 \text { clear glass }\end{array}$ & \\
\hline Lv. $6(50-60)$ & & 11 plastic, 1 fla glass,, 1 clear glass & \\
\hline Lv. 7 (60-70) & & 1 semi-porcelain, & \\
\hline \multicolumn{4}{|c|}{ ST 20} \\
\hline Lv. $1(0-10)$ & $\begin{array}{l}\text { Dark brown (10YR3/3) sandy clay loam, } \\
\text { few pebbles }\end{array}$ & $\begin{array}{l}1 \text { brick, } 1 \text { can lid, } 6 \text { plaster, } 1 \text { clear glass, } 1 \\
\text { lamp glass }\end{array}$ & \\
\hline Lv. $2(10-20)$ & $\begin{array}{l}\text { Olive brown }(2.5 \mathrm{Y} 4 / 4) \text { sandy clay loam, } 1- \\
5 \% \text { pea gravels }\end{array}$ & $\begin{array}{l}1 \text { undec white earthenware, } 1 \text { brown glass, } 10 \\
\text { clear glass, } 1 \text { flat glass, } 2 \text { lamp glass, } 5 \text { plaster, } \\
1 \text { wire nail, iron scrap, } 2 \text { bone, } 1 \text { plain-colored } \\
\text { glazed ware, }\end{array}$ & \\
\hline Lv. $3(20-30)$ & \multirow[t]{5}{*}{$\begin{array}{l}\text { Light olive brown }(2.5 \mathrm{Y} 5 / 6) \text { sandy loam, } \\
1 \% \text { pea gravels }\end{array}$} & $\begin{array}{l}2 \text { clear glass } 1 \text { wire nail, } 1 \text { hollow, cuprous } \\
\text { arrow tip }\end{array}$ & \\
\hline Lv. $4(30-40)$ & & None & \\
\hline Lv. $5(40-50)$ & & None & \\
\hline Lv. 6 (50-60) & & None & \\
\hline Lv. 7 (60-70) & & None & \\
\hline \multicolumn{4}{|c|}{ ST 21} \\
\hline Lv. $1(0-10)$ & $\begin{array}{l}\text { Hard-packed light gray }(2.5 \mathrm{Y} 7 / 2) \text { sandy } \\
\text { loam }\end{array}$ & 1 plastic tag, 1 wire nail, 10 clear glass & \\
\hline Lv. $2(10-20)$ & \multirow[t]{2}{*}{$\begin{array}{l}\text { Hard-packed light yellowish brown } \\
(2.5 \mathrm{Y} 6 / 4) \text { sandy loam }\end{array}$} & $\begin{array}{l}1 \text { galvanized wire nail with spiral grooves, } 2 \\
\text { brick, } 1 \text { lead glazed ware, } 4 \text { clear glass, } 1 \text { aqua } \\
\text { glass }\end{array}$ & \\
\hline Lv. $3(20-30)$ & & 1 lithic, 1 brick & \\
\hline Lv. $4(30-40)$ & $\begin{array}{l}\text { Hard-packed pale yellow (2.5Y7/4) sandy } \\
\text { loam }\end{array}$ & None & \\
\hline Lv. $5(40-50)$ & $\begin{array}{l}\text { Light yellowish brown }(2.5 \mathrm{Y} 6 / 4) \text { sandy } \\
\text { loam }\end{array}$ & None & \\
\hline Lv. $6(50-58)$ & Pale yellow (2.5Y7/4) sandy loam & None & \\
\hline \multicolumn{4}{|c|}{ ST 22} \\
\hline Lv. $1(0-10)$ & $\begin{array}{l}\text { Light yellowish brown }(2.5 \mathrm{Y} 6 / 4) \text { sandy } \\
\text { clay loam }\end{array}$ & $\begin{array}{l}3 \text { foil, } 3 \text { brown glass, } 7 \text { olive glass, } 1 \text { bone, } 7 \\
\text { clear glass, } 3 \text { crown cap frag }\end{array}$ & \\
\hline
\end{tabular}


Table A-1. continued...

\begin{tabular}{|c|c|c|c|}
\hline Level (cmbs) & \begin{tabular}{|c|} 
Sediment \\
\end{tabular} & Artifacts & Notes \\
\hline Lv. $2(10-20)$ & $\begin{array}{l}\text { Pale yellow }(2.5 \mathrm{Y} 7 / 4) \text { clay loam, with small } \\
\text { amounts of gravel and concrete fragments }\end{array}$ & None & \\
\hline Lv. $3(20-30)$ & $\begin{array}{l}\text { Light yellowish brown }(2.5 \mathrm{Y} 6 / 4) \text { silty clay } \\
\text { loam with small amounts of gravel and } \\
\text { concrete fragments }\end{array}$ & iron scrap & \\
\hline Lv. $4(30-40)$ & \multirow{4}{*}{$\begin{array}{l}\text { Pale yellow (2.5Y7/4) sandy clay loam, } \\
\text { with small amounts of gravel }\end{array}$} & None & \\
\hline Lv. $5(40-50)$ & & None & \\
\hline Lv. 6 (50-60) & & None & \\
\hline Lv. 7 (60-70) & & None & \\
\hline \multicolumn{4}{|c|}{ ST 23} \\
\hline \multicolumn{4}{|c|}{ Encountered concrete @ $3 \mathrm{cmbs}$} \\
\hline \multicolumn{4}{|c|}{ ST 24} \\
\hline Lv. $1(0-10)$ & $\begin{array}{l}\text { Light yellowish brown (10YR6/4) loamy } \\
\text { sand, 5\% gravel }\end{array}$ & None & \\
\hline Lv. $2(10-20)$ & $\begin{array}{l}\text { Light yellowish brown }(2.5 \mathrm{Y} 6 / 4) \text { clay loam, } \\
5 \% \text { gravel }\end{array}$ & None & \\
\hline Lv. $3(20-30)$ & $\begin{array}{l}\text { Light yellowish brown }(2.5 \mathrm{Y} 6 / 4) \text { clay loam, } \\
5 \% \text { gravel, with several large }(10-15 \mathrm{~cm}) \\
\text { river cobbles }\end{array}$ & $\begin{array}{l}3 \text { bone, } 1 \text { German porcelain, iron scrap, } 1 \\
\text { plaster, } 1 \text { clear glass medicine bottle with } \\
\text { metal stopper, } 21 \text { clear glass }\end{array}$ & \\
\hline Lv. $4(30-40)$ & $\begin{array}{l}\text { Light yellowish brown }(2.5 \mathrm{Y} 6 / 4) \text { clay loam, } \\
5 \% \text { gravel, with several large }(7-10 \mathrm{~cm}) \\
\text { river cobbles }\end{array}$ & $\begin{array}{l}8 \text { bone, } 1 \text { brick, } 2 \text { brown glass, } 2 \text { aqua glass, } \\
30 \text { clear glass, } 3 \text { lamp glass, } 1 \text { porcelain, iron } \\
\text { scrap }\end{array}$ & \\
\hline Lv. $5(40-50)$ & $\begin{array}{l}\text { Light yellowish brown }(2.5 \mathrm{Y} 6 / 4) \text { clay loam, } \\
20 \% \text { pea gravels }\end{array}$ & iron scrap, 1 clear glass & \\
\hline Lv. $6(50-60)$ & $\begin{array}{l}\text { Light yellowish brown }(2.5 \mathrm{Y} 6 / 4) \text { clay loam, } \\
20 \% \text { pea gravels }\end{array}$ & None & \\
\hline Lv. 7 (60-70) & $\begin{array}{l}\text { Pale yellow (2.5Y7/4) clay loam, } 5 \% \text { pea } \\
\text { gravels }\end{array}$ & None & \\
\hline \multicolumn{4}{|c|}{ ST 25} \\
\hline Lv. $1(0-10)$ & $\begin{array}{l}\text { Olive brown }(2.5 \mathrm{Y} 4 / 4) \text { clay loam, grass } \\
\text { roots }\end{array}$ & $\begin{array}{l}2 \text { foil, } 5 \text { plastic, } 1 \text { brown glass, } 2 \text { plaster, } 3 \\
\text { mortar, iron scrap, } 12 \text { clear glass, } 6 \text { lamp } \\
\text { glass, } 21 \text { bone }\end{array}$ & \\
\hline Lv. $2(10-20)$ & \multirow[t]{2}{*}{$\begin{array}{l}\text { Light brownish gray (10YR6/2) clay loam, } \\
1-5 \% \text { pea gravels }\end{array}$} & 2 wire nail, 3 clear glass, 1 brown glass & \\
\hline Lv. $3(20-30)$ & & 2 brown glass, 1 clear glass & \\
\hline Lv. $4(30-40)$ & \multirow[t]{2}{*}{$\begin{array}{l}\text { Light yellowish brown }(2.5 \mathrm{Y} 6 / 4) \text { silty clay } \\
\text { loam, charcoal flecks }\end{array}$} & 1 wire nail, 1 clear glass, 2 lamp glass, & \\
\hline Lv. $5(40-50)$ & & $\begin{array}{l}3 \text { bone, iron scrap, } 1 \text { wire nail, } 1 \text { green glass, } 1 \\
\text { brown glass, } 3 \text { clear glass, } 2 \text { lamp glass }\end{array}$ & \\
\hline Lv. $6(50-60)$ & $\begin{array}{l}\text { Pale brown }(10 \mathrm{YR} 6 / 3) \text { silty clay loam, } 5- \\
10 \% \text { pea gravels, a few cobbles }(5-7 \mathrm{~cm}), \\
\text { charcoal flecks }\end{array}$ & $\begin{array}{l}1 \text { eyelet, } 2 \text { mortar, } 1 \text { lead glazed ware, } 3 \text { lamp } \\
\text { glass, } 1 \text { brown glass, } 1 \text { green glass, } 2 \text { clear } \\
\text { glass, iron scrap, copper scrap }\end{array}$ & \\
\hline Lv. 7 (60-70) & $\begin{array}{l}\text { Pale brown (10YR6/3) silty clay loam, 5- } \\
10 \% \text { pea gravels, charcoal flecks }\end{array}$ & $\begin{array}{l}1 \text { purpled glass, } 1 \text { green glass, } 1 \text { wire nail, iron } \\
\text { scrap }\end{array}$ & \\
\hline
\end{tabular}


Table A-1. continued...

\begin{tabular}{|c|c|c|c|}
\hline Level (cmbs) & Sediment & Artifacts & Notes \\
\hline \multicolumn{4}{|c|}{ ST 29} \\
\hline LV. $1(0-10)$ & Brown (10YR5/3) sandy clay loam, roots & $\begin{array}{l}2 \text { brick, } 1 \text { concrete, } 1 \text { brown glass, } 2 \text { lamp } \\
\text { glass, } 2 \text { clear glass, } 3 \text { leather frag }\end{array}$ & \\
\hline Lv. $2(10-20)$ & $\begin{array}{l}\text { Hard-packed olive yellow }(2.5 \mathrm{Y} 6 / 6) \text { sandy } \\
\text { clay loam, occasional cobbles }(5-7 \mathrm{~cm})\end{array}$ & 2 pvc pipe frag, 1 brown glass, 2 clear glass & \\
\hline Lv. $3(20-30)$ & \multirow{5}{*}{$\begin{array}{l}\text { Light yellowish brown }(2.5 \mathrm{Y} 6 / 4) \text { sandy clay } \\
\text { loam }\end{array}$} & 1 brown glass & \\
\hline Lv. $4(30-40)$ & & None & \\
\hline Lv. $5(40-50)$ & & None & \\
\hline Lv. $6(50-60)$ & & None & \\
\hline Lv. 7 (60-70) & & None & \\
\hline & & ST 30 & \\
\hline Lv. $1(0-10)$ & \multirow[t]{2}{*}{$\begin{array}{l}\text { Light brownish gray }(10 \mathrm{YR} 6 / 2) \text { sandy clay } \\
\text { loam, } 10 \% \text { pea gravels }\end{array}$} & $\begin{array}{l}2 \text { bone, } 3 \text { green glass, } 39 \text { clear glass, } 6 \text { flat } \\
\text { glass, } 15 \text { lamp glass }\end{array}$ & \\
\hline Lv. $2(10-20)$ & & iron scrap, 4 clear glass, 7 lamp glass & \\
\hline Lv. $3(20-30)$ & $\begin{array}{l}\text { Pale yellow }(2.5 \mathrm{Y} 7 / 4) \text { sandy clay loam, }<5 \\
\% \text { pea gravels }\end{array}$ & 1 melted glass, 1 flat glass & \\
\hline Lv. 4 (30-40) & $\begin{array}{l}\text { Light yellowish brown (2.5Y6/4) sandy clay } \\
\text { loam }\end{array}$ & None & \\
\hline Lv. 5 (40-50) & \multirow[t]{3}{*}{ Pale yellow (2.5Y7/4) sandy loam } & None & \\
\hline Lv. 6(50-60) & & None & \\
\hline Lv. 7 (60-70) & & None & \\
\hline \multicolumn{4}{|c|}{ ST 31} \\
\hline Lv. $1(0-10)$ & $\begin{array}{l}\text { Brown (10YR5/3) sandy clay loam with } \\
\text { roots and brick fragments }\end{array}$ & $\begin{array}{l}2 \text { bone, } 3 \text { plastic, } 1 \text { mortar, } 7 \text { clear glass, iron } \\
\text { scrap, } 1 \text { flat glass }\end{array}$ & \\
\hline Lv. $2(10-20)$ & \multirow[t]{2}{*}{$\begin{array}{l}\text { Light olive brown }(2.5 \mathrm{Y} 5 / 4) \text { sandy clay } \\
\text { loam, } 5 \% \text { gravels and roots }\end{array}$} & $\begin{array}{l}1 \text { wire nail, } 1 \text { white earthenware, } 1 \text { brown } \\
\text { glass, } 3 \text { clear glass }\end{array}$ & \\
\hline Lv. $3(20-30)$ & & None & \\
\hline Lv. $4(30-40)$ & \multirow{2}{*}{$\begin{array}{l}\text { Light yellowish brown }(2.5 \mathrm{Y} 6 / 4) \text { silty clay } \\
\text { loam }\end{array}$} & None & \\
\hline Lv. $5(40-50)$ & & 1 lithic & \\
\hline Lv. $6(50-60)$ & \multirow[t]{2}{*}{ Pale yellow (2.5Y7/4) silty clay loam } & None & \\
\hline Lv. 7 (60-70) & & None & \\
\hline \multicolumn{4}{|c|}{ ST 32 } \\
\hline \multicolumn{4}{|c|}{ Encountered concrete @ $3 \mathrm{cmbs}$} \\
\hline \multicolumn{4}{|c|}{ ST 33 } \\
\hline Lv. $1(0-10)$ & \multirow{2}{*}{$\begin{array}{l}\text { Light olive brown }(2.5 \mathrm{Y} 5 / 4) \text { sandy clay } \\
\text { loam, }<5 \% \text { gravels and roots }\end{array}$} & 2 lamp glass, 1 mortar, 1 brick & \\
\hline Lv. $2(10-20)$ & & $\begin{array}{l}2 \text { foil, } 4 \text { clear glass, } 1 \text { lamp glass, } 2 \text { brown } \\
\text { glass, } 1 \text { olive glass, iron scrap }\end{array}$ & \\
\hline Lv. $3(20-30)$ & $\begin{array}{l}\text { Olive brown }(2.5 \mathrm{Y} 4 / 4) \text { silty sand, } 10-20 \% \\
\text { pea gravels }\end{array}$ & $\begin{array}{l}1 \text { undec white earthenware, } 3 \text { brown glass, } 1 \\
\text { olive glass, } 7 \text { clear glass, } 5 \text { lamp glass }\end{array}$ & \\
\hline Lv. $4(30-40)$ & $\begin{array}{l}\text { Light olive brown (2.5Y5/4) sandy clay } \\
\text { loam, } 30-40 \% \text { pea gravels }\end{array}$ & 1 olive glass, 1 clear glass, iron scrap & \\
\hline Lv. 5 (40-50) & $\begin{array}{l}\text { Light yellowish brown (2.5Y6/4) silty clay } \\
\text { loam }\end{array}$ & 1 hand painted ware, iron scrap, 3 plastic & \\
\hline Lv. $6(50-60)$ & \multirow[t]{2}{*}{ Pale yellow (2.5Y7/4) silty clay loam } & 2 plastic, 1 clear glass & \\
\hline Lv. 7 (60-70) & & 1 brick & \\
\hline
\end{tabular}




\section{Appendix B: Data from Shovel Tests at 41SR337 (The Coffee Pot Café)}


Table B-1. Data from Shovel Tests at 41SR337

\begin{tabular}{|c|c|c|c|}
\hline Level (cmbs) & Sediment & Artifacts & Notes \\
\hline \multicolumn{4}{|c|}{ ST 08} \\
\hline Lv. $1(0-10)$ & $\begin{array}{l}\text { Light grayish brown }(10 \text { YR } 6 / 2) \text { sandy clay } \\
\text { loam, }<5 \% \text { pea gravels }\end{array}$ & $\begin{array}{l}\text { vinyl fragments, clear glass fragments } \\
\text { (vessel body sherd molded and not) }\end{array}$ & \\
\hline Lv. $2(10-20)$ & Grayish brown $(2.5 Y 5 / 2)$ sandy clay loam & $\begin{array}{l}7 \text { asbestos tile frags., } 2 \text { clear glass frag., } \\
\text { iron scrap, }\end{array}$ & \\
\hline Lv. $3(20-30)$ & $\begin{array}{l}\text { Grayish brown }(2.5 \mathrm{Y} 5 / 2) \text { clay loam, with } \\
\text { charcoal flecks }\end{array}$ & $\begin{array}{l}\text { Numerous red brick fragments (not } \\
\text { collected), } 19 \text { unidentified bone, } 5 \\
\text { asbestos tile frags., } 3 \text { wire nails, iron scrap }\end{array}$ & \\
\hline Lv. $4(30-40)$ & \multirow{2}{*}{$\begin{array}{l}\text { Ashy light grayish brown (10YR6/2) clay } \\
\text { loam, with numerous charcoal flecks }\end{array}$} & iron scrap and bone frags. & \\
\hline Lv. $5(40-50)$ & & $\begin{array}{l}1 \text { Hand Painted frag., bone frag, iron } \\
\text { scrap, } 1 \text { wire nail, } 1 \text { mica }\end{array}$ & \\
\hline Lv. $6(50-60)$ & \multirow[t]{2}{*}{ Light grayish brown (10YR6/2) sandy loam } & 1 unglazed, 1 hand painted, iron scrap & \\
\hline Lv. $7(60-70)$ & & None & \\
\hline \multicolumn{4}{|c|}{ ST 09} \\
\hline Lv. $1(0-10)$ & $\begin{array}{l}\text { Grayish brown (10YR5/2) sandy clay loam, } \\
\text { sparse charcoal flecks }\end{array}$ & $\begin{array}{l}\text { plastic, } 1 \text { lead nail seal, } 1 \text { drk olive glass, } \\
1 \text { aqua glass, bone, brick, } 1 \text { lamp glass, } \\
\text { iron scrap, } 1 \text { clear glass }\end{array}$ & \\
\hline Lv. $2(10-20)$ & $\begin{array}{l}\text { Brown (10YR5/3) sandy clay loam, sparse } \\
\text { charcoal flecks }\end{array}$ & $\begin{array}{l}1 \text { lead glazed frag., } 1 \text { brown glass, } 5 \text { clear } \\
\text { glass, iron scrap, } 8 \text { bone }\end{array}$ & \\
\hline Lv. $3(20-30)$ & $\begin{array}{l}\text { Grayish brown (10YR6/2) clay loam, } \\
\text { sparse charcoal flecks }\end{array}$ & $\begin{array}{l}1 \text { brick frag, } 18 \text { bone, } 1 \text { drk olive glass, } 1 \\
\text { Lusterware, } 1 \text { undec. white earthenware, } 1 \\
\text { Transfer ware, } 2 \text { hand painted, } 2 \text { Galera, } 2 \\
\text { lead glazed, } 1 \text { brown glass, iron scrap }\end{array}$ & \\
\hline Lv. $4(30-40)$ & $\begin{array}{l}\text { Light yellowish brown }(2.5 \mathrm{Y} 6 / 4) \text { clay } \\
\text { loam, sparse charcoal flecks }\end{array}$ & $\begin{array}{l}2 \text { Annular, } 1 \text { hand painted, } 1 \text { undec. White } \\
\text { earthenware, } 1 \text { Galera, } 1 \text { Roma ware, } 1 \\
\text { wire nail, } 1 \text { brick, } 1 \text { flat glass, } 1 \text { chain } \\
\text { link, } 21 \text { bone }\end{array}$ & \\
\hline Lv. $5(40-50)$ & $\begin{array}{l}\text { Light olive brown ( } 2.5 \text { Y } 5 / 4) \text { clay loam, } \\
\text { sparse charcoal flecks }\end{array}$ & $\begin{array}{l}1 \text { brick, } 1 \text { undec. white earthenware, } 1 \\
\text { sponge ware, } 1 \text { Transfer, } 1 \text { charcoal, } 1 \\
\text { lithic, } 39 \text { bone }\end{array}$ & $\begin{array}{l}\text { Transferware with polychrome } \\
\text { clobbering (ca. 1842-1867) }\end{array}$ \\
\hline Lv. $6(50-60)$ & \multirow{2}{*}{$\begin{array}{l}\text { Light olive brown }(2.5 Y 5 / 4) \text { clay loam, } 5- \\
10 \% \text { pea gravels, river cobbles }(5-7 \mathrm{~cm}) \\
\text { sparse charcoal flecks }\end{array}$} & $\begin{array}{l}1 \text { concrete, } 1 \text { cut nail, } 1 \text { tile, } 3 \text { lithic, } 16 \\
\text { bone }\end{array}$ & \\
\hline Lv. $7(60-70)$ & & None & \\
\hline \multicolumn{4}{|c|}{ ST 10 } \\
\hline Lv. $1(0-10)$ & $\begin{array}{l}\text { Olive brown }(2.5 \mathrm{Y} 4 / 4) \text { sandy clay loam, } \\
<5 \% \text { pea gravels }\end{array}$ & $\begin{array}{l}1 \text { clear glass, } 1 \text { sponge ware, } 1 \text { bone, } 1 \\
\text { mussel shell, } 1 \text { lead glazed, } 1 \text { mica }\end{array}$ & \\
\hline Lv. $2(10-20)$ & $\begin{array}{l}\text { Light olive brown }(2.5 \mathrm{Y} 5 / 4) \text { sandy clay } \\
\text { loam, }<5 \% \text { pea gravels }\end{array}$ & $\begin{array}{l}2 \text { clear glass, } 2 \text { mortar, } 1 \text { unidentified } \\
\text { ceramic, } 3 \text { asphalt }\end{array}$ & \\
\hline Lv. $3(20-30)$ & $\begin{array}{l}\text { Pale brown (10YR6/3) sandy loam, } 50 \% \\
\text { pea gravels, and numerous flecks of } \\
\text { crushed mortar }\end{array}$ & 2 concrete, 1 brick, 1 lithic & \\
\hline
\end{tabular}


Table B-1. continued...

\begin{tabular}{|c|c|c|c|}
\hline Level (cmbs) & Sediment & Artifacts & Notes \\
\hline Lv. $4(30-40)$ & $\begin{array}{l}\text { Light yellowish brown }(2.5 \mathrm{Y} 6 / 4) \text { loamy } \\
\text { sand, } 50 \% \text { pea gravels }\end{array}$ & 1 mortar, 2 lithic, 1 concrete & \\
\hline Lv. $5(40-50)$ & $\begin{array}{l}\text { Pale brown (10YR6/3) sandy loam, } 40 \% \\
\text { pea gravels, and numerous flecks of } \\
\text { crushed mortar, some fragments of slag }\end{array}$ & $\begin{array}{l}2 \text { cobalt glass, } 3 \text { undec white earthenware, } \\
4 \text { tar, } 1 \text { bone, } 1 \text { ironstone, iron scrap, } 3 \\
\text { lithic, } 4 \text { brick, } 11 \text { flat glass, } 1 \text { lead glazed }\end{array}$ & \\
\hline Lv. $6(50-60)$ & \multirow[t]{2}{*}{$\begin{array}{l}\text { Light brownish gray }(2.5 \mathrm{Y} 6 / 2) \text { sandy loam, } \\
30 \% \text { pea gravels }\end{array}$} & $\begin{array}{l}1 \text { porcelain button, } 3 \text { mussel shell, } 1 \text { olive } \\
\text { glass, } 3 \text { brown glass, } 3 \text { lithic, } 2 \text { brick, } 17 \\
\text { bone, } 3 \text { clear glass, } 1 \text { spatterware, } 1 \\
\text { transferware, } 1 \text { edgeware, } 2 \text { undec white } \\
\text { earthenware } 1 \text { Galera, } 4 \text { lead glazed, } 1 \\
\text { Roma ware, } 4 \text { cut nail, iron scrap }\end{array}$ & \\
\hline Lv. 7 (60-70) & & $\begin{array}{l}17 \text { bone, } 1 \text { human molar, } 1 \text { undec white } \\
\text { earthenware, iron scrap, } 4 \text { brick, } 1 \\
\text { concrete }\end{array}$ & \\
\hline \multicolumn{4}{|c|}{ ST 17} \\
\hline Lv. $1(0-10)$ & $\begin{array}{l}\text { Brown }(10 \mathrm{YR} 5 / 3) \text { sandy clay loam, } \\
\text { charcoal flecks }\end{array}$ & $\begin{array}{l}1 \text { mica, } 1 \text { brown glass, } 1 \text { mortar, } 1 \text { bone, } 1 \\
\text { plaster, } 1 \text { brick, } 1 \text { lamp glass, } 1 \text { olive } \\
\text { glass, } 1 \text { clear glass }\end{array}$ & \\
\hline Lv. $2(10-20)$ & Grayish brown (10YR5/2) sandy loam & $\begin{array}{l}3 \text { brick, } 2 \text { green glass, } 2 \text { mica, } 8 \text { bone, } 3 \\
\text { clear glass, } 3 \text { asphalt, } 1 \text { screw, iron scrap }\end{array}$ & \\
\hline Lv. $3(20-30)$ & $\begin{array}{l}\text { Grayish brown (10YR5/2) sandy loam, } \\
\text { charcoal flecks }\end{array}$ & $\begin{array}{l}\text { iron scrap, } 1 \text { brown glass, } 1 \text { flat glass, } 5 \\
\text { clear glass, } 1 \text { bone, } 1 \text { brick }\end{array}$ & \\
\hline Lv. $4(30-40)$ & $\begin{array}{l}\text { Light grayish brown (10YR6/2) sandy clay } \\
\text { loam }\end{array}$ & $\begin{array}{l}1 \text { bone, } 2 \text { tar, } 1 \text { lithic, } 2 \text { concrete, } 1 \text { undec } \\
\text { white earthenware, } 1 \text { lead glazed, } 1 \\
\text { stoneware, } 11 \text { clear glass, } 1 \text { aqua glass }\end{array}$ & \\
\hline Lv. $5(40-50)$ & \multirow[t]{2}{*}{ Grayish brown $(2.5 \mathrm{Y} 5 / 2)$ sandy clay loam } & $\begin{array}{l}1 \text { bone, iron scrap, } 3 \text { clear glass, } 1 \text { plaster, } \\
1 \text { lithic }\end{array}$ & \\
\hline Lv. $6(50-60)$ & & 3 bone, 1 drk olive glass, 1 lithic & \\
\hline Lv. 7 (60-67) & $\begin{array}{l}\text { Light brownish gray }(2.5 \mathrm{Y} 6 / 2) \text { sandy clay } \\
\text { loam }\end{array}$ & 1 bone, iron scrap, 1 concrete & \\
\hline \multicolumn{4}{|c|}{ Terminated @ $67 \mathrm{~cm}$ due to large limestone rocks } \\
\hline \multicolumn{4}{|c|}{ ST 18} \\
\hline Lv. $1(0-10)$ & $\begin{array}{l}\text { Olive brown }(2.5 \mathrm{Y} 4 / 4) \text { sandy clay loam, } \\
10 \% \text { pea gravels, grass roots }\end{array}$ & 1 lead glazed, 2 lithic, 1 ceramic tile & \\
\hline Lv. $2(10-20)$ & $\begin{array}{l}\text { Olive brown }(2.5 \mathrm{Y} 4 / 4) \text { sandy clay loam, } \\
15 \% \text { pea gravels }\end{array}$ & 1 slate frag & \\
\hline Lv. $3(20-30)$ & $\begin{array}{l}\text { Light olive brown }(2.5 \mathrm{Y} 5 / 4) \text { sandy clay } \\
\text { loam, } 15 \% \text { pea gravels }\end{array}$ & $\begin{array}{l}2 \text { brown glass, } 1 \text { vinyl, } 2 \text { olive glass, } 1 \\
\text { lead glazed } 1 \text { lead nail seal, } 2 \text { lithic, iron } \\
\text { scrap, } 2 \text { mussel shell, } 2 \text { purpled glass }\end{array}$ & \\
\hline
\end{tabular}


Table B-1. continued...

\begin{tabular}{|c|c|c|c|}
\hline Level (cmbs) & \begin{tabular}{|c|} 
Sediment \\
\end{tabular} & Artifacts & Notes \\
\hline Lv. $4(30-40)$ & \multirow[t]{4}{*}{ Grayish brown (10YR5/2) sandy loam } & $\begin{array}{l}8 \text { bone, } 1 \text { olive glass, } 1 \text { clear glass, } 2 \\
\text { undec white earthenware, } 1 \text { hand painted, } \\
1 \text { lithic, } 1 \text { mortar, } 8 \text { Roma ware, }\end{array}$ & \\
\hline Lv. $5(40-50)$ & & iron scrap, 1 mussel umbo & \\
\hline Lv. $6(50-60)$ & & $\begin{array}{l}\text { iron scrap, } 2 \text { lead glazed, } 1 \text { Galera, } 1 \text { tile, } \\
1 \text { Tonala }\end{array}$ & \\
\hline Lv. 7 (60-70) & & $\begin{array}{l}1 \text { concrete, } 1 \text { lead glazed, } 4 \text { bone, } 1 \text { drk } \\
\text { olive glass, } 1 \text { lithic, } 1 \text { hand painted, } 1 \\
\text { clear glass, } 1 \text { lamp glass }\end{array}$ & \\
\hline \multicolumn{4}{|c|}{ ST 19} \\
\hline Lv. $1(0-10)$ & \multirow[t]{3}{*}{ Grayish brown (10Y5/2) sandy clay } & 1 pvc pipe, 1 lithic, iron scrap & \\
\hline Lv. $2(10-20)$ & & $\begin{array}{l}1 \text { plastic, } 4 \text { bone, } 3 \text { wire nail, } 6 \text { can frag, } 1 \\
\text { fence staple }\end{array}$ & \\
\hline Lv. $3(20-25)$ & & 1 bone, 1 s-link & \\
\hline \multicolumn{4}{|c|}{ Terminated @ 25 cm due to cast iron pipe in center of unit } \\
\hline \multicolumn{4}{|c|}{ ST 26} \\
\hline Lv. $1(0-10)$ & Pale brown (10YR6/3) sandy clay loam & $\begin{array}{l}3 \text { foil, } 1 \text { mica, } 1 \text { "High Life" crown cap } \\
\text { and bottle neck, } 1 \text { clear glass }\end{array}$ & \\
\hline Lv. $2(10-20)$ & \multirow[t]{4}{*}{ Light yellowish brown $(2.5 \mathrm{Y} 6 / 4)$ clay loam } & 1 bone, 1 wire nail, 1 lead glazed & \multirow[t]{2}{*}{ Rodent hole } \\
\hline Lv. $3(20-30)$ & & $\begin{array}{l}5 \text { bone, } 1 \text { brown glass, } 1 \text { brick, } 1 \text { lead } \\
\text { glazed }\end{array}$ & \\
\hline Lv. $4(30-40)$ & & 2 brick, 1 tile & \\
\hline Lv. 5 (40-50) & & $\begin{array}{l}1 \text { brown glass, } 1 \text { lamp glass, } 1 \text { flat glass, } \\
\text { charcoal }\end{array}$ & \\
\hline Lv. $6(50-60)$ & \multirow[t]{2}{*}{$\begin{array}{l}\text { Light grayish brown }(10 \mathrm{YR} 6 / 2) \text { sandy clay } \\
\text { loam, few small }(5-7 \mathrm{~cm}) \text { river cobbles }\end{array}$} & $\begin{array}{l}1 \text { wire nail, } 3 \text { plaster, } 3 \text { brick, } 1 \text { lithic, } 1 \\
\text { brown glass, } 4 \text { bone }\end{array}$ & \\
\hline Lv. 7 (60-70) & & $\begin{array}{l}1 \text { bone, } 1 \text { plaster, } 1 \text { clear glass, iron scrap, } \\
1 \text { undec white earthenware }\end{array}$ & \\
\hline \multicolumn{4}{|c|}{ ST 27 } \\
\hline Lv. $1(0-10)$ & $\begin{array}{l}\text { Olive brown }(2.5 \mathrm{Y} 4 / 4) \text { sandy clay loam, } \\
<5 \% \text { pea gravels }\end{array}$ & 1 flat glass & \\
\hline Lv. $2(10-20)$ & Light grayish brown (10YR6/2) sandy loam & iron scrap & \\
\hline Lv. $3(20-30)$ & \multirow[t]{2}{*}{ Pale brown (10YR6/2) sandy loam } & $\begin{array}{l}1 \text { syringe cover, } 1 \text { foil, } 2 \text { bone, iron scrap, } \\
1 \text { hand painted ware, } 2 \text { clear glass, } 1 \text { aqua } \\
\text { glass, } 2 \text { plaster }\end{array}$ & \\
\hline Lv. $4(30-40)$ & & $\begin{array}{l}2 \text { plastic, } 1 \text { bone, } 2 \text { lamp glass, } 1 \text { terra } \\
\text { cotta, iron scrap }\end{array}$ & \\
\hline Lv. $5(40-50)$ & \multirow[t]{2}{*}{ Light yellowish brown (2.5Y6/4) clay loam } & $\begin{array}{l}5 \text { mica, } 1 \text { olive glass, } 1 \text { brown glass, } 1 \\
\text { clear glass, } 1 \text { peach glass, } 1 \text { porcelain, } 1 \\
\text { undec white earthenware, } 1 \text { lithic, iron } \\
\text { scrap, } 1 \text { fence staple }\end{array}$ & \\
\hline Lv. $6(50-60)$ & & 2 sewer pipe frags (ceramic) & \\
\hline
\end{tabular}


Table B-1. continued...

\begin{tabular}{|c|c|c|c|}
\hline Level (cmbs) & Sediment & Artifacts & Notes \\
\hline \multicolumn{4}{|c|}{ ST 28} \\
\hline Lv. $1(0-10)$ & \multirow[t]{3}{*}{ Brown (10YR5/3) sandy loam } & $\begin{array}{l}1 \text { brown glass, } 1 \text { electrical artifact, iron } \\
\text { scrap, } 1 \text { flat glass, } 2 \text { non-ferrous metal, } 1 \\
\text { concrete, } 1 \text { tar, }\end{array}$ & \\
\hline Lv. $2(10-20)$ & & 1 tar 1 mortar, 2 clear glass, 1 aqua glass & \\
\hline Lv. $3(20-30)$ & & $\begin{array}{l}1 \text { syringe needle, } 3 \text { mortar, } 1 \text { unglazed } \\
\text { ware, } 2 \text { mica, } 1 \text { clear glass, iron scrap }\end{array}$ & \\
\hline Lv. $4(30-40)$ & \multirow[t]{4}{*}{$\begin{array}{l}\text { Pale brown (10YR6/2) sandy loam, } \\
\text { charcoal flecks }\end{array}$} & $\begin{array}{l}\text { iron scrap, } 1 \text { undec white earthenware, } 8 \\
\text { bone, } 2 \text { clear glass }\end{array}$ & \\
\hline Lv. $5(40-50)$ & & $\begin{array}{l}1 \text { green glass bottle, } 1 \text { bone, } 1 \text { mussel } \\
\text { shell, } 1 \text { olive glass, } 1 \text { hand painted ware, } \\
\text { iron scrap, } 1 \text { flat glass, } 1 \text { mortar, } 1 \\
\text { possible gunflint }\end{array}$ & $\begin{array}{l}\text { possible gunflint is similar to style found } \\
\text { at Fort St. Louis }\end{array}$ \\
\hline Lv. $6(50-60)$ & & 1 lamp glass, iron scrap, 2 mortar & \\
\hline Lv. 7 (60-70) & & None & \\
\hline \multicolumn{4}{|c|}{ ST 34} \\
\hline Lv. $1(0-10)$ & \multirow{3}{*}{$\begin{array}{l}\text { Pale brown }(10 \mathrm{YR} 6 / 3) \text { sandy clay loam, } \\
\text { numerous pieces of plaster }\end{array}$} & & \\
\hline Lv. $2(10-20)$ & & $\begin{array}{l}5 \text { bone, } 1 \text { lithic, } 1 \text { tar, } 1 \text { cut spongeware, } 1 \\
\text { undec white earthenware, } 1 \text { yellow glass, } \\
2 \text { wire nail }\end{array}$ & \\
\hline Lv. $3(20-30)$ & & $\begin{array}{l}1 \text { hand painted, } 1 \text { brick, } 1 \text { clear glass, } \\
\text { charcoal, } 1 \text { plaster, iron scrap }\end{array}$ & \\
\hline Lv. $4(30-40)$ & \multirow{3}{*}{$\begin{array}{l}\text { Light gray (10YR7/2) sandy loam, with lots } \\
\text { of caliche and plaster }\end{array}$} & 1 mortar, 1 brick, 8 plaster & \\
\hline Lv. $5(40-50)$ & & $\begin{array}{l}1 \text { brown, glass, } 1 \text { clear glass, } 1 \text { clear glass } \\
\text { bottle, } 1 \text { mortar, } 5 \text { plaster, } 1 \text { brick, iron } \\
\text { scrap }\end{array}$ & \\
\hline Lv. $6(50-60)$ & & 1 bisque frag, 2 bone, 3 mortar & \\
\hline Lv. 7 (60-70) & Pale brown (10YR6/3) sandy clay loam & None & \\
\hline \multicolumn{4}{|c|}{ ST 35} \\
\hline Lv. $1(0-10)$ & \multirow[t]{4}{*}{ Pale brown (10YR6/3) sandy loam } & 3 clear glass, 1 flat glass, 1 plastic button & \\
\hline Lv. $2(10-20)$ & & None & \\
\hline Lv. $3(20-30)$ & & $\begin{array}{l}3 \text { bone, } 1 \text { olive glass, } 2 \text { lead glazed, iron } \\
\text { scrap }\end{array}$ & \\
\hline Lv. $4(30-38)$ & & $\begin{array}{l}1 \text { bone, } 3 \text { clear glass, } 1 \text { concrete, iron } \\
\text { scrap }\end{array}$ & \\
\hline & Terminat & ted @ $38 \mathrm{~cm}$ at two iron pipes & \\
\hline
\end{tabular}


Table B-1. continued...

\begin{tabular}{|c|c|c|c|}
\hline Level (cmbs) & Sediment & Artifacts & Notes \\
\hline \multicolumn{4}{|c|}{ ST 36} \\
\hline Lv. $1(0-10)$ & \multirow{7}{*}{$\begin{array}{l}\text { Pale brown (10YR6/3) sandy loam, } \\
\text { charcoal flecks }\end{array}$} & 1 concrete, 1 lithic & \\
\hline Lv. $2(10-20)$ & & 1 mortar & \\
\hline Lv. $3(20-30)$ & & $\begin{array}{l}3 \text { mortar, } 2 \text { aqua glass, } 1 \text { flat glass, } 1 \text { wire } \\
\text { nail, iron scrap }\end{array}$ & \\
\hline Lv. $4(30-40)$ & & $\begin{array}{l}5 \text { sewer pipe frag, } 1 \text { lead glazed, iron } \\
\text { scrap, } 1 \text { mortar, } 5 \text { clear glass, } 1 \text { white } \\
\text { earthenware }\end{array}$ & \\
\hline Lv. $5(40-50)$ & & $\begin{array}{l}1 \text { flat glass, } 1 \text { concrete, iron scrap, } 1 \\
\text { cuprous frag. }\end{array}$ & \\
\hline Lv. $6(50-60)$ & & iron scrap, 1 concrete, 1 brick & \\
\hline Lv. 7 (60-70) & & 1 tile, 1 lithic, iron scrap & \\
\hline
\end{tabular}

